\title{
THE \\ AMERICAN FEDERATION OF ARTS
}

PUBLISHED BY

THE NATIONAL ACADEMY OF ART 


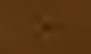




\section{PROCEEDINGS \\ OF THE}

\section{CONVENTION}

AT WHICH

THE AMERICAN

FEDERATION OF ARTS

WAS FORMED

Held at WASHINGTON, D. C.

MAY 11th, 12th and 13th, 1909
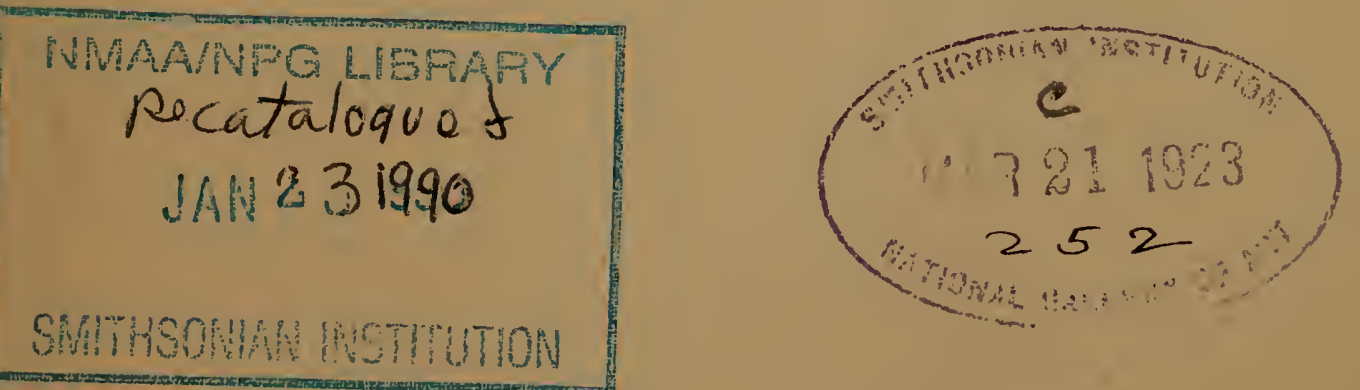

$$
\begin{array}{cc}
1909 \\
\text { PRESS OF BYRON S. ADAMS } \\
\text { Warhington, D. C. }
\end{array}
$$





\title{
PROCEEDINGS
}

OF THE

\section{CONVENTION AT WHICH THE AMERICAN FEDERATION OF ARTS WAS FORMED}

\author{
FIRST SESSION. \\ Tuesday Morning, May 11, 1909.
}

The convention met in the Red Parlor of the New Willard Hotel, at 10.05 o'clock, Mr. Charles L. Hutchinson of Chicago, 1st Vice-President of the National Academy of Art, in the chair.

The Chairman: Ladies and Gentlemen: The Regents of the National Academy of Art have called this convention, and in the absence of its President, it is my duty, and my privilege, to preside, and the Secretary of the National Academy of Art, Mr. Glenn Brown, will act as Secretary until the permanent organization shall be effected.

Before we proceed to carry out the programme in your hands, I will announce a Committee on Credentials: Marvin F. Scaife of Pittsburg, Chairman; William M. Ellicott of Baltimore, and W. L. Harris of New York. That Committee can be found in the rear of the room and we will ask all delegates to present their names and credentials to that Committee.

It is seldom that a Chairman is called upon to preside at a meeting where the duty is made so easy as it is this morning. Nearly every one who is to address us has a national reputation, so that any introduction on the part of the Chairman would perhaps be a presumption. It was suggested, before the opening of the meeting, that the session of this morning was essentially a Vice-Presidents' meeting, since the VicePresident of the National Academy of Art presides, and the Vice-President of the United States is to bid us welcome.

I have the honor of presenting the Vice-President of the United States. (Applause.) 
ADDRESS OF

Hon. James Schoolcraft Sherman, Vice-President of the United States.

Mr. Chairman, and Delegates to this Federation Meeting: I am delighted to see ladies are more numerously represented than the men. That augurs well for the success of the meeting, because when the ladies, if I may use that expression, "put their hand to the plow the sod turns over." (Laughter.)

I congratulate you upon the purposes for which you have met. Having said that much, I am to stop on that line, because the distinguished former Secretary of State and now the great Senator from the State of New York, will enlighten you, if you do not already know, upon the purposes for which this meeting is held. I am not to make an address, as the Chairman has said, but simply to bid you welcome, and that I am delighted to do.

I congratulate you upon choosing this beautiful Capital City, of this great, progressive nation of ours as the place for that meeting; I congratulate you on choosing this season of the year, when all Nature smiles; when we have here in Washington our bridal gown on in which to bid you welcome.

I sincerely trust that the objects for which you have come together will be distinctly furthered by this gathering. I bid you welcome, not simply as an individual, but on behalf of the Government, of which I am a small part mentally, not physically. (Laughter.) This is a great and splendid Government of ours, and well are we proud of it. We have always been foremost in everything that we have undertaken. We started in arms, and from 1776 down to now, our beattiful starry banner has never been lowered to any colors on the face of the earth. (Applause.) We pride ourselves most, however, in our history, not of arms, but of peace. Despite the carping of the critics, we have devoted much attention to our progress in material things-aye, and we have devoted it for a purpose, too, because that devotion has put us in the forefront of the commercial nations of the world. We stand today foremost as a commercial nation, foremost as an ex- 
porting nation, foremost as a manufacturing nation, foremost in railroad mileage, foremost in all practical pursuits, of all the peoples of the civilized world. It is not just today that we have began to devote our attention in a measure to the arts and sciences. We have been doing that for some little time, and for the last decade, at least, yes, nearer two decades, we have witnessed material progress in our appreciation of all that is artistic and beautiful, and, as you know, what we desire to do now is amalgamate the interests which tend to promote, here in our midst, all that is beautiful, not merely in painting, nor in sculpture, but in all matters of landscape, of flowers and of trees and of streets, and of parks, all, in fact, that tends to make our surroundings beautiful and bright and pure and healthful. That, I understand, is what this convention is purposing to do, and my heart is in sympathy with it and with every organization and individual that is struggling to better our condition, either in material things or in that which is artistic and beautiful.

I trust, my friends, that assembling here will bring to you all, and to each, much pleasure and much profit. I am sure that the meeting will differ materially from the last meeting which I addressed in this city, because I know there will be no bickerings in your midst; I know there will be no ambitions to gratify, other than the one ambition-to do that which betters humanity in general, and which improves our condition locally-locally, not simply applied to Washington, but locally as applied to the home city, to the home town of each citizen in our country. I trust that when you have concluded your deliberations that you will return in health, in comfort, and in ease to your several homes, carrying with you pleasant recollections of your stay here, enthusiasm for the beauty and the cleanliness of your national city, increased patriotism, increased love of country, and an earnest desire to assist in every way, which comes within your power, in the preservation of all that is beautiful, and the development of that which is artistic, in America. (Applause.)

The Chairman. In seeking a title for the next speaker, I find myself somewhat embarrassed. It is difficult to think of 
Mr. Root as attached to New York as a Senator, for he belongs to the whole country, and we know him as "Secretary." So, I am going to introduce him as a man fond of the beautiful, who lends his aid for the support of every good cause, for the betterment and the culture of the community. (Applause.)

I take great pleasure in introducing Mr. Root. (Applause.)

ADDRESS OF

Hon. Elihu Root,

Senator from New York.

Mr. Chairman, Ladies and Gentlemen: The Vice-President's agricultural simile, in which he puts the women's hands to the plow, reminds me of the old proverb: "He who would by farming thrive, himself must hold the plow, or drive," and I suggest that the distribution of labor should be that the men should put their hands to the plow and the women should drive. (Laughter and applause.)

I have been asked to state the purpose of this meeting. because I was one of a little group of men who for a long period, from time to time, met at the home of our lamented friend, Mr. Ffoulke, for the purpose of working out a means to utilize the charter that has been granted by Congress for the National Academy of Art, in such a way as to accomplish what we felt here, from our rather central point of view. in the national capital, was a very important object, and was an object for which the time was ripe in the United States.

The object of this convention is to organize a federation of all institutions, societies, city and village improvement associations, and school and other organizations in the United States, whose purpose is to promote the study of art, the cultivation of the public taste, and the application of art to the development of material conditions in our country. This is the age of concentration, co-operation and combination, and it is not necessary to explain the advantages of team-work over individual effort. All of the leading professions have national organizations, except those that are interested in such 
objects as I have mentioned. The lawyers have the American Bar Association, the doctors have the American Medical Association, the historians the American Historical Association, and the scientists the American Association for the Advancement of Science.

It has been suggested that we can do no better than to follow the example of the Fine Arts Federation of New York City, a co-operative association that has accomplished results in that city which could not have been attained by the constituent societies working independently. The American Institute of Architects furnishes another admirable example of the powerful and consistent influence upon the national development in artistic direction that can be exercised by separate associations and societies working in co-operation. It is proposed to organize those who are interested in the fine arts in a similar manner under the auspices of the National Academy of Art, which was incorporated by Congress in 1892 with wide corporate powers, and has its headquarters in this city, with Mr. J. Pierpont Morgan of New York, that most liberal patron of fine arts, as its President.

There are two hundred and twenty-two schools and public art galleries in one hundred and sixty-two different cities and towns in the United States. Sixty-eight of these schools offer money prizes to their students for meritorious work, ranging from $\$ 100$ to $\$ 3,000$. Seven million dollars were given last year in the United States in the form of endowments, bequests, and other financial contributions to the promotion of art in the United States.

More than fifty cities have municipal art leagues or associations for the improvement of appearances, for extending their park systems, widening their streets, improving their pavements, setting out trees, securing public buildings of higher architectural merit, better school houses, lecture courses and public exhibitions under municipal control, and for a general betterment and the education of the public taste and public opinion on artistic lines. There are hundreds of village improvement associations for similar purposes, the first of which was organized more than fifty years ago. 
There is a general movement throughout the entire country to preserve the beauty of our natural scenery and to secure an improvement in the looks of things, both natural and artificial, and it is spreading rapidly. It is believed that this movement may be promoted and public sentiment developed in favor of its purpose by uniting the many local organizations scattered throughout the country in a National Federation for mutual encouragement and co-operation.

The specific objects of such a federation as we propose may be enumerated as follows:

1. To encourage the organization of art societies; the establishment of art schools and art galleries; to encourage the exhibition of private art collections for the benefit of the public; to encourage American artists, and to aid in securing higher recognition for merit.

2. To encourage the study of art in the public schools, particularly in the towns and villages; to encourage boards of education, school superintendents, and the faculties of seminaries, academies, colleges and universities, to pay more attention to the cultivation of the taste of their students and to teach them correct ideas in art and the advantage of making things beautiful.

3. To encourage the appointment of competent commissions in municipalities and States to supervise public architecture, monuments, parks, plans, and other improvements in order that they may be in accordance with the best rules of art.

4. To improve the standard of private architecture; to encourage the planting of trees, shrubbery, hedges in the farms and door yards, and whatever may be done to embellish the public streets of cities, towns, and villages.

5. To support the plan of the Park Commission for beautifying the City of Washington, and to aid in persuading Congress to follow its suggestions in the location of future public buildings, monuments, and other improvements at the $\mathrm{Na}$ tional Capital.

6. To assist in preserving natural scenery from destruction and desecration; to extend the National Park system, the forest reserves, and preservation of historic and natural landmarks. 
7. To promote the movement for public playgrounds, school gardens, and other efforts to cultivate the love of nature and of art in the minds of children.

8. To support the movement for the enlargement of the jurisdiction of the Supervising Architect of the Treasury, and the organization of a Bureau of Arts which shall have supervision of all public buildings, monuments, and other improvements ordered by Congress throughout the United States; and the appointment, pursuant to legislation, of an advisory council of experts to advance the standard of public architecture.

9. To support and advance the National Gallery of Art, which has already been established under the Smithsonian Institution by gifts and bequests of important collections from the late Harriet Jane Johnston of Washington, Mr. Wm. T. Evans of New York, and Mr. Charles L. Freer of Detroit.

10. To assist in securing the erection of an appropriate building for the National Gallery at Washington corresponding to the Congressional Library and the National Museum.

11. To afford an organization through which the general opinion of all Americans who are lovers of beauty in art and in nature may find expression and be made effective as from time to time public questions shall arise which ought to be determined by the highest standards of taste.

It is expected that the delegates here assembled, if they approve the purpose and plan of the National Academy of Art, will organize a Federation, adopt a constitution and by-laws, elect officers, and appoint a place and a time for another meeting.

We have arranged a program of addresses upon topics bearing upon the purpose of the organization by speakers eminent in their professions, and we hope that the discussions which are expected to follow them will be freely participated in by all of the delegates.

We hope that from the development of this movement, drawing into its stream the multitudes of smaller streams of purpose and of effort which already exist in our country, will come, for the people of America in a high degree, that increase of happiness that is to be found in the cultivation of taste and the opportunity for its enjoyment. (Prolonged applause.) 
The Chairman. As announced in the programme, it is your privilege to ask, after any address, any questions you may desire, or make any suggestions you wish. If you care to address any questions to Senator Root, he will be glad to answer them.

Mr. Root. Excluding the tariff!

The Chairman. He excludes the tariff from the fine arts. My idea is that there is much fine art in'the tariff. (Laughter.) The task he has set for this organization is a noble and a great one, but, as he said, it is not impossible with proper organization and with proper spirit inspiring such organization.

We are under great obligations, Senator, for your very able address. (Applause.).

On motion of Mr. Frank C. Baldwin, of Detroit, that the committees on framing a constitution and on the selection of place and date for the next convention be appointed on the first, instead of the second, day of the convention, it was so ordered, after which the Chairman introduced the Hon. Francis S. Newlands, Senator from Nevada.

The Chairman. As a Western man it is with considerable pride that $I$ announce the next speaker. We all know the need of a greater and perhaps a more sane supervision of everything pertaining to the fine arts that come under the control of our National Government, and to find a man from the far West as the champion of such a move in Congress is a. matter of pride to every Westerner. 


\title{
A GOVERNMENT BUREAU OF FINE ARTS.
}

\author{
ADDRESS OF \\ Hon. Francis S. Newlands, \\ Senator from Nevada.
}

Mr. Chairman, Ladies and Gentlemen: I was quite surprised when I received a telephone message from my secretary this morning that I was expected to be present at this gathering today, for I had supposed that the meeting was to be tomorrow, and I have been so engaged in the confusion of the tariff discussion that $I$ have not been able to gather together even the few thoughts which I have upon this subject. I presume that $I$ owe the honor of addressing this gathering to the fact that at the last session of Congress I introduced a bill enlarging the scope and power and authority of the office of the Supervising Architect of the Treasury, expanding it into a Bureau of Architecture and the Fine Arts; and organizing in connection with it a Council of the Fine Arts, such as Senator Root has referred to. That bill has not yet been considered by any committee, and it is not probable that it will come up for consideration until the next session of Congress.

I regret to say that in the very early stages of this legislation the whole question became somewhat complicated by reason of the action-the very worthy action-of President Roosevelt, who, eager as he is always, to do good things-himself, without the authority of Congress, appointed a Council of Fine Arts. I have no doubt, myself, that he had the power to call into conference with himself and other executive officers, experts in architecture and the fine arts, to advise with him, and with them, regarding contemplated Government structures. But he went a little bit farther than this, and it is claimed by Congress that he trenched upon legislative authority, and you know Congress is rather jealous of its legislative authority and disposed to resent any intrusion upon it. So this Council of Arts, an admirable body of men, composed of distinguished artists of the country, whilst it was called into being did not exist for a great length of time, though I must say that in the short session which they held here they per- 
formed distinguished service for the country in creating and forming public opinion with reference to the importance of preserving the Burnham Plan, so far as it related to the Lincoln Memorial. (Applause.)

National work in the line of art involves, ultimately, it seems to me, the creation of a Ministry of Arts, such as they have in other countries, such as they have in France, in Germany, in Italy and Austria, where the chief officer is one of the Cabinet, so to speak, of the ministry, one of the leading advisers of the Government. I would have been glad to have introduced a bill organizing a Ministry of the Fine Arts in the United States, but I felt that the mind of the average legislator was hardly prepared for that, for art is oftentimes regarded as a dangerous thing, conducing to extravagance in administration. We have not as yet realized that art is really a thing of utility, that it is a thing of practical commercial value, a thing which enters into the happiness and the well being of everyone and every occupation, and that our highest purpose should be to make the useful things beautiful.

The Government of the United States has been engaged in a great constructive work; it is engaged in work-constructive work-in public buildings. It is now engaged in the constructive work of irrigation; it is engaged in the constructive work of building the Panama Canal. It has been, in a sporadic kind of a way, engaged in improving our rivers and harbors. The time doubtless will come, and before long, when all of the great constructive work of the country will be thoroughly organized, under a great Board of Public Works, in which and connected with which will be the best engineers of the country, the great architects of the country, and with which will be identified the great artists of the country, for in the improvement particularly of our rivers and harbors, we should have in view the artistic development of the water fronts of every town upon a harbor (Applause) ; and of every city upon a harbor (Applause); and if this work of artistic development is pursued contemporaneously with the structural work we will have a union of art and of utility. 
In this great work the United States, it seems to me, should lead, and the States should follow; and we should have, so far as the organization of this movement is concerned, an organization similar to that of the general government and the State governments. You will observe that in all the organizations that are now in existence in the country-the law organization, to which Senator Root has referred, the architects' organization-that they have local organizations in each State in which are represented the various local organizations of the villages, cities and towns-and then we have the national organization, to which the State organizations send their representatives. If we can accomplish something of that kind regarding art, and incorporate together in some organized movement all the various societies that have reference to art, including not only sculpture and painting, but music, in which so many are interested (Applause), we will form a public sentiment that will have a powerful influence upon Congress itself. You all realize that Congress rarely leads in the creation of public opinion-it follows public opinionand it is necessary that we should have outside of Congress organizations of people devoted to some great purpose, with a view to impressing Congress with the importance of that public opinion and its powerful influence and interest in affairs.

The United States has entered already upon some work of education-practical education, it is true. We organized the Bureau of Agriculture, in the first instance, and then we expanded it into a Department of Agriculture, and that Department has had a great and powerful influence in every State in the Union in the advancement of Agriculture. Congress very wisely, in connection with the establishment of the Bureau, and, subsequently, Department of Agriculture, organized Agricultural Schools in every State in the Union. These schools, as a rule, are connected with the State Universities, the money supplied by Congress for their support amounting, I believe, in each instance to about $\$ 40,000$ or $\$ 50,000$ per annum, which aid greatly in the maintenance of struggling universities in small States and Territories. These schools have been the center of dissemination of the experience and 
the instruction of the central Department of Agriculture, and have been in close communication with the Department of Agriculture, their professors, for instance, coming on here and accepting details in particular service in the Department of Agriculture, so that when they return to their respective schools they return there with a broad influence and culture arising from being brought into contact with national interests and affairs.

Congress went further in that-it added to these schools of agriculture the mechanic arts, so that these schools are now called Schools of Agriculture and the Mechanic Arts; and it is proposed, and I have no doubt the project will be carried through, to add to the jurisdiction of these schools mining, so that we will have Schools of Agriculture, Mining and the Mechanic Arts. It seems to me that the existing organization furnishes an opportunity for adding the Fine Arts in these various schools of the various States, and if a movement were inaugurated by this association calling upon Congress to add the fine arts to the jurisdiction of these schools now devoted to agriculture, mining, and the mechanic arts that we would build up in every State in the Union an organization that will be a powerful aid in the national movement. It might probably result later on in the organization-in the development of a Ministry or Department of Architecture and Fine Arts here, and in connection with it we would probably have a School of the Fine Arts, a school devoted to Sculpture, Painting and Music, as well as to Architecture. We would have here a great conservatory devoted to the Fine Arts, having its branches in every State in the Union, and receiving its support from these local organizations.

Our Government is so complex with its State and National administration that it is important in many of these matters that we should have a more effective co-operation between the States and the general government than is now enjoyed, for there are many powers that the States have which the National Government has not, and there are powers that the National Government has which the States have not; and it is only by the union of these powers through some recognized system of co-operation that we can accomplish all that we 
want in the desired direction. In this scheme of organization, with the nation at the head, and the States following, it is quite probable that we will have in time, as a result of this process of evolution, a great National University, such as Washington contemplated-a university intended to bring the young people of all parts of the country into contact with each other, and destroy that sectionalism and provincialism which are likely to exist, unless the people of all parts of the country come into immediate association with each other. Such a National University, devoted largely, perhaps, to subjects not now covered by the State Universities, would be an immense factor in the general development of the countrythe general development of the culture and the artistic taste of the country.

I venture these few practical remarks with reference to this matter, and I trust that you will find the opportunity, during your discussions here, to formulate some method of action that will bring about co-operation between the States and the $\mathrm{Na}$ tional Government in this great work, and will, above all things, create a strong and powerful public opinion that will force action from a reluctant Congress. (Prolonged applause.)

The Chairman. The next speaker upon our programme is a lady, and it is, therefore, a fitting time to pay a tribute to Kate Field, who was chiefly instrumental in obtaining from Congress the charter of the National Academy of Art, the Regents of which have called us together. You all know her devotion to the Fine Arts. We lament her loss, but she has noble followers, and competent successors, among whom, perhaps, there is none more competent to address us upon the "Relation of the Government to the Fine Arts" than Miss Leila Mechlin. 
THE GOVERNMENT AND THE FINE ARTS.

\section{ADDRESS OF \\ Miss Leila Mechlin.}

Mr. Chairman and Fellow Delegates: Despite the fact that the Government has expended over five hundred million dollars, since its establishment, on buildings and other works of art, such as statues and paintings, it cannot be said to have deliberately patronized the fine arts, as it is quite easy to divorce art from its hypothetical manifestations, and the fact of buying largely by no means validates a claim to connoisseurship. To an extent the incidence of the tariff is illustrative of the attitude assumed, throughout, by the Government in regard to all matters pertaining to the fine arts. Not only, as we all know, has the duty been retained for years upon works of art which would have had a highly educational value, serving to develop taste and stimulate artistic mechantile production, but, through lack of expert knowledge on the part of those appointed to adjudicate claims, forgeries have been unwittingly authenticated and foolish discriminations made. In like manner, to be brief, the Government has failed to encourage actively the development of native art, has placed a premium on mediocrity, and has made expenditures in this particular field in a manner which in private enterprise would be condemned as unbusinesslike and improvident.

It is not my intention, however, to deal in generalities, but rather to give concrete examples-instances which have come come under my personal observation during the past nine years in my capacity as art writer for one of the Washington papers.

Mrs. Harriet Lane Johnston, the niece of President Buchanan, died in July, 1903, bequeathing to the Corcoran Gallery of Art her collection of paintings, historical documents, and so forth, with the provision that if at any time a National Gallery should be established the bequest should be given into its custody. Now it so happened when the Smithsonian Institute was established in 1846 it was made the custodian of all works of art belonging to the nation, and steps were taken, by the 
regents, to procure and maintain a gallery; plans for exhibitions and a school were considered; and, in 1849, with excellent judgment, the sum of $\$ 4,000$ was expended for the Marsh collection of prints. But that is as far as the matter was carried and as the years passed the project was lost sight of and eventually forgotten. Fortunately, however, the Corcoran Gallery declined Mrs. Johnston's bequest, and the heirs being desirous that the collection should not be disbursed, the nation set about discovering a way to rightfully claim it, and unearthed a slumbering institution. A decree of the Supreme Court of the District of Columbia, issued in July, 1906, declared that the United States possessed a National Gallery. Mrs. Johnston's collection was turned over to the Smithsonian Institution and temporary accommodations were provided for it by the $\mathrm{Na}$ tional Museum. Since then Mr. William T. Evans, of New York, has presented to the Nation a collection of paintings by American artists-a collection of very considerable value and one which a few years hence, in all probability, could not be assembled-which is now set forth in the atrium of the Corcoran Gallery of Art, where more than two years ago it was placed as a loan. Meanwhile Congress has been asked to provide a home for these collections, the appropriation of a comparatively small sum which would permit the remodeling of a hall in the Smithsonian building being requested. No response, however, has been made. Not one cent has been given by Congress toward the establishment, maintenance, or development of a national gallery, and the present situation is deplorable. The Johnston pictures in the Museum Hall are seen to poor advantage, the Evans pictures at the Corcoran Gallery are not only cramped for space, but occupying walls which the Corcoran Gallery can ill spare, being obliged on this account to store some of its own exhibits. Mr. Evans has said that as there is no place to exhibit more paintings he will be unable for the present to make further accessions, and there is little doubt that other persons are being deterred from making gifts by the same reason.

To go back, however. While the settlement of Mrs. Johnston's estate was pending, Mr. Charles L. Freer, of Detroit, offered to give his collection of paintings, prints, potteries, and 
other art objects, valued at $\$ 600,000$, to the nation, in the sponsorship of the Smithsonian Institution, promising to bequeath, in addition, the sum of $\$ 500,000$, for the erection of a building in which it should be housed. In making this offer, Mr. Freer requested that experts be sent to his home to inspect and appraise the collection. Here was indeed a princely offer made in a manner eminently fair, but it aroused no enthusiasm on the part of the Government. There was fear expressed that $\mathrm{Mr}$. Freer might be building a monument to himself which the Government should be obliged to maintain; experts were not called upon to testify as to the worth of the collection; and the value of Whistler's productions, in which it was especially rich, was amiably discussed by those who laid no claim to connoisseurship in art though learned in science. "Was he really great or merely eccentric?" "Would his pictures be reckoned masterly two centuries hence?" were among the questions which proved stumbling blocks to ready acceptance. Finally when it began to look as though further delay would mean eventual loss the matter was brought to the attention of the President and a meeting was called at the White House, at which the subject was warmly discussed and a decision arrived at. Now it is possible that if Mr. Roosevelt had not interfered the result would have been the same, but the situation at the time he took hold of it was to all appearances dubious. Of course, no one can say positively what might have happened under other conditions-I am only telling what really did happen.

Every Government Department has a portrait gallery of its own, it being customary for every out-going secretary to sit for his portrait to a painter whom he or his successor may select. This gives opportunity for ample patronage and the accession of some valuable works, but a glance at the collections will show it, for the most part, to have been wasted. More than a few commissions within the past nine years have gone to a commercial photographer who has let them out to painters willing to accept work from any source, much as a contractor would sub-let a piece of brick-laying. (Laughter.) The wonder is not that the majority are so bad but so good.

And whenever an exposition is held the Government is 
obliged to seek the aid of artists. Each Department makes an exhibit, a portion of which is ofttimes pictorial. In one instance it was thought desirable to have pictures of all the battleships painted, and the commission was given to a draftsman at the Navy Yard who was essentially an amateur in this field. The results were commendable but photographic, clever but not works of art, accurate but not pictorial, and to make things worse, real rope, gilded, was utilized in part, for the frames. (Laughter.) Doubtless they were worth all they cost, but that is not the question. (Laughter.)

It is possible that one may point to the Library of Congress in confutation of the statement that the Government has not deliberately patronized art as art. But let us look into this matter. A surplus was left from the original appropriation for the building and this, with permission, was utilized for the mural paintings which serve as decorations. The amount was altogether inadequate to recompense the artists for their work but as an opportunity to prove what might be done it was accepted and the unpaid-for labor cheerfully donated. These decorations are not all as good as the painters themselves now wish they might be, but they have lent impetus to mural painting and had a far-reaching effect.

A parallel case -is to be cited in the Custom House at Baltimore. The architects through care and justifiable economy were able to save out of the appropriation a sufficient sum to permit the employment of a mural painter of distinction, into whose hands, it was their desire to intrust the decoration of the entire building. When this was made known to the Secretary of the Treasury, under whose authority the work was being done, he refused permission, saying that he would sanction money being spent for marble and wood but not for paintings, and he only finally yielded when the architects presented their plea in person and proved its logic. To their persistence, rather than his good judgment, is due the existence today of one of the most perfectly decorated buildings in the United States. (Applause.)

Since the passage of the Tarsney Act, permitting the employment of architects not in Government service, and the reorganization of the Supervising Architect's office under Mr. 
James Knox Taylor, there has been a marked improvement in the type of buildings which the Government has erected. In the early days of the Republic excellent taste was manifested and the best talent employed for this purpose. Then came a long period of Stygian darkness from which we are but just emerging, and from which some of our law-makers have not yet emerged. Very recently it was proposed to erect a building for the Census Office which should be so plain and homely in appearance, for the sake of economy, that it was thought advisable to suggest that it be erected in an out-ofthe-way place-a proposal against which, I believe, but one Senator made vigorous protest. And on the twenty-second of February when the question of the Fine Arts Council, appointed by President Roosevelt, was being debated in the House of Representatives, a member, drifting away from the matter under discussion, asked, in all seriousness, if the insistence upon new plans and specifications for each new building erected was not a subterfuge to keep certain draftsmen employed? advocating, to prevent this extravagance, the "keeping in stock" of sets of specifications and plans for, say, $\$ 30,000, \$ 40,000, \$ 50,000$, and $\$ 60,000$ buildings. (Laughter and applause.)

A little town in Texas is to have a new church, the plans for which have been prepared by one of the leading firms of American architects-a firm especially eminent for their ecclesiastical designs-and a resident of that town, who is especially interested, wrote me, that it had been a liberal education to the citizens to discover that good art of this type commanded so good a price-was worth so much in hard cash. This is, unhappily, not often the case. The feeling which seems to prevail on the part of the Government-or those who represent it-is that artists may be over-paid. More than once I have been asked how many hours it must have taken a sculptor, an architect, or a painter, to execute a certain work, how much his material cost, and then, if his profits did not seem enormous; the years of labor spent in apprenticeship to gain the ability to accomplish such a result being entirely overlooked.

There is, undoubtedly, such a thing as extravagant economy, and in many instances, especially where art is concerned, it is. 
practiced by the Government. The chief charge brought against the Park Commission's plan for the future artistic development of Washington was that it was too costly, though in fact it is no more expensive to follow a good plan than a poor one, and while a large total would have eventually been reached, it would have extended over so many years that at no time would it have proved appreciably burdensome. It seems exceedingly remarkable that this plan, secured through the foresight and wisdom of a few, which has been endorsed by experts in all parts of the world, and has stimulated artistic city building in every part of our country, has never been accepted or authorized by the National Government, and that while certain features of it have been developed it has only been on account of powerful outside intervention and against violent protests. That this plan had to be "slipped on at one time and in at another," to use President Taft's words, is, in itself, a commentary upon the art sense of the Government. For it is not only artists and architects who this plan impressed favorably, but such men of affairs as the late $\mathrm{Mr}$. Cassatt, president of the Pennsylvania Railroad, who was willing to sacrifice money interests for it, and the members of the Chambers of Commerce of such practical, hustling cities as Buffalo and Chicago. The American Institute of Architects has stood sponsor to this plan from the beginning, and has prevented, by eternal vigilance, its final operation being perpetually blocked. For this it is entitled to the gratitude of the nation but because of it, it has come to be regarded in certain quarters with distinct disfavor. Nor is the battle by any means won. Riverside Park is to be developed, Rock Creek Valley to be opened up and parked, the Anacostia flats turned into a pleasure ground, and the water front improved-all large projects requiring years for execution. We may all feel, with President Taft, that this plan will be followed, but we have only our confidence in its intrinsic merit as a reason for our faith.

Turning, however, to the subject of sculpture. Within the last nine years the Government has awarded commissions for nine statues to be erected in Washington, a pair of bronze doors, and a pediment for the Capitol. Seven of the statue 
commissions were given through competition-a method which it is well known rarely brings forth the best results. Not that I would say that all these nine statues are, or are going to be, poor, from the standpoint of art, but I do say that they will not be the best which might have been secured. Too often it seems that the Government, like Cadet Derby, having the choice of a good and a bad apple, voluntarily takes the latter, but with less excuse. Scrutinizing carefully the statues in Washington commemorating our military heroes, one is forced to conclude that Mr. Mabie was right in merely "cherishing the hope that posterity might realize they were erected through ignorance and not in malice." (Applause.) To be sure there are exceptions, some striking ones, but it will only be necessary to compare the Sherman statue south of the Treasury with the Sherman statue on the Plaza, New York, to appreciate my meaning. (Applause.)

Last of all, attention may be called to the proposal concerning a Lincoln memorial which was so strongly agitated last winter; a proposal to utilize the sentiment attached to a memorial of Lincoln, and aroused by the celebration of the centenary of his birth, to get an appropriation through Congress for the purchase of the land lying between the Capitol and the Union Station. Twenty-five thousand dollars was appropriated by Congress seven years ago in order that a committee might look into the subject of a suitable memorial to Lincoln and secure plans. A member of this committee went abroad and made an exhaustive study of memorials, collected data, and, about the time the bill for the memorial adjacent to the Union Station was introduced into Congress, made a report, advising the construction of a roadway from Washington to Gettysburg, one of the features of which should be the sculpture along its length, presented and erected by each of the States. Shortly after this a third bill was introduced authorizing the site selected by the Burnham Park Commission on the river front at the Washington terminus of the proposed Memorial Bridge to Arlington - a site already belonging to the Government and endorsed by experts. Nothing is to be said against the acquisition of the land adjacent to the Capitol-unquestionably it should be purchased by the Government-and only 
commendation can be given the really beautiful dcsign for a semi-circular peristyle on the plaza of the Station which was proposed as the memorial, but it is plain that neither should have been contingent upon an appeal to sentiment, nor entertained when they did not accomplish the declared object.

I do not wish to give the impression that everything pertaining to the fine arts is done hopelessly in the dark-that nothing is good-that no progress is being made. If, indeed, the case were as bad as that, there would be little encouragement for effort. More and more frequently now expert advice is sought, and though not always followed, better results are being attained. This, however, is invariably through individual intervention-the wisdom of those who chance to hold office, and must not be mistaken as an evidence of permanent progress. It is not Governmental.

In spite of certain enlightenment the impression still prevails that art is an effeminate luxury, a token of decadent aristocracy, a veneer costly and unnecessary. We are still prone to pride ourselves over-much on being plain citizens and on having commonsense-mistaking crudity for simplicity and ignorance for logic. This is partly through ignorance and partly through lack of confidence on the part of laymen in artists. It is difficult, I admit, for the average lay mind to comprehend the vagaries of the artistic temperament-to avoid confusion through the diversity of opinion regarding matters artistic, and to understand the way in which artists attain professional standing. But this can be remedied. Members of Congress, Cabinet officers, and Army engineers cannot be required to be connoisseurs in art-to have trained knowledge along this line, but it is possible for the Government to place the administration of the fine arts, not arbitrarily but regularly, in the hands of art experts, men who have given years of study to the subjects and are specially qualified for the trust. This, as Senator Newlands has just explained, would be the purpose of a National Bureau of Fine Arts.

The question is, how can the present conditions be remedied and this result be attained? And I answer, not by the effort of any one, nor of a few, but through the co-operation of all. If the farmer in North Dakota, the fruit grower in California, 
the mill owner in Massachusetts, the miner in Colorado, the cattle raiser in Texas, can be convinced that the wise administration of the fine arts by the Government would mean something to them, something to their children, something tangible and practical, the thing would be half accomplished, yes, more than half. For though we talk a good deal about autocracies, ours is, in fact, a government of the people. The great trouble is that the majority of the people do not care, and what is everybody's business is nobody's business. And here it is that such a Federation as it is proposed to organize at this convention should be able to lend valuable aid-not by passing resolutions and offering petitions but by carrying through its federated associations the message home and inducing active interest in all sections.

It is true that we are a young nation, that we have been busy developing our industries and opening up a vast territory; but we have grown rich and prosperous and come in a measure to maturity. It is now we must decide, whether, henceforth, we shall buy gold or tinsel-whether we shall build monuments which will testify to the most, or to the least, enlightenment we have attained-whether, as the President of Columbia University has said, we shall cultivate the public taste up or down. (Applause.)

At the conclusion of Miss Mechlin's address, the Chairman, seeing the British Ambassador enter the room, invited him to take a seat on the platform, after which he announced the appointment of the following committees:

On Constitution and By-Laws.-Frank D. Millet, Chairman; Geo. W. Cable, Daniel C. French, Allan Marquand, Mrs. F. O. Lowden, Arthur Jeffrey Parsons and Henry Read.

On Nominations.-Dr. Chas. W. Needham, Chairman; Wm. M. R. French, C. Grant La Farge, Florence N. Levy, Theodore Marburg, Leila Mechlin, and Hennen Jennings.

The Chairman then introduced the British Ambassador, who had consented to speak. 
ADDRESS OF

Right Hon. James Bryce, O. M., Ambassador from Great Britain.

Mr. Chairman, Ladies and Gentlemen: I find myself called upon, very unexpectedly indeed, to say a few words to you, and I have the more regret that I was not able to hear the part of the proceedings which have already passed this morning, from which I might at least have derived some suggestions as to topics to which it would be suitable to offer some remarks. However, as I am called upon thus, and as I understand this is a meeting open for free discussion, I will obey your Chairman and say what comes into my mind, suggested by the purposes which bring you together.

I was asked by Mr. William E. Curtis, some days ago, to tell you what has been done in Great Britain, in the way of bringing general canons of architectural taste to bear upon public buildings, and especially what statutes, or local regulations, existed preventing the unfortunate results which arise from erecting side by side buildings in different styles and of different heights, each marring the effect of the other. There was very little time to ascertain what our laws in Great Britain were on the subject. However, I wrote at once to a friend there, and I received, by cable, the answer which I expected, namely, that we have not got those statutes and regulations. This is very melancholy, because I should have been in a very strong position if I had been able to come before you and tell you what we had done in England, holding it up as a model for you! It would have been a beautiful thing for the old country, which claims to have done something in originating institutions which have been developed further in this country, if it had been able to pose as a leader and standard bearer in the cultivation of art in its public aspects and in the bringing of legal weight to bear upon the artistic growth of cities! Unfortunately, that is not so.

I will tell you, Mr. President, as far as my recollection goes, what are the only ways in which we do incidentally prevent 
the disfiguring of cities by improper buildings, but, meantime, let me tell you that those who love art and taste in England, and in particular the organizations of architects themselves have for a long time past been endeavoring to obtain some public regulation of streets and buildings. So far they have failed. They have failed for an obvious reason, which no doubt would be operative here also. They have supposed that regulations by public authority would infringe what are called the sacred rights of property. Now, property is a very good thing in its way, but property sometimes carries its demands a little too far, and that because the right of ownership of a piece of land is vested in an individual, he should therefore have the right to put up buildings which may not only destroy the general beauty of a street or square, but may also destroy the beauty and effectiveness of buildings directly adjoining them which some man of better taste and higher public spirit has erected, with a view to the public enjoyment, as well as his own, would seem to be going a little too far. You may recall the words of Madame Roland at the time of the French Revolution, who said, "O, Liberty, what crimes are committed in thy name!" And I feel sometimes inclined, when I see the extravagant demands that are made in the name of property, to say, "O, property, what atrocities are justified in thy name!" (Laughter and applause.)

It seems unlikely that for sometime to come we can, at any rate by public authority, secure that which we may call the censorship, or supervision of the erection, style, design, and size, of buildings to be erected in streets and squares, which I understand the members of this association desire. But, one must not despair of the future. After all, there is some progress marked by this mere fact that many more people desire the thing now than desired it formerly. There is furthermore this consolation, which we may apply to our minds, when we regret the absence of legal regulation-that if legal regulation had existed in former times we might have had things done which we should now regret. We might have had whole lines of streets, or large squares and circles built in styles which we should now think uninteresting and monotonous, merely because they represented the particular dominant taste 
and tendency of a particular time. Note, for instance, what was done by Baron Haussmann, when he built so large a part of the great thoroughfares of Paris in the day of Louis Napoleon. Most of us would now feel that those long lines of boulevards are monotonous and, indeed, many people would call them dull and soulless. Certainly there is far too much of that sort of thing in Paris. That was the style of the time. Haussmann was able to carry out the ideas which he, or somebody else for him, endeavored to apply, and the consequence was that the picturesqueness and charm of old Paris vanished. A great many of its quaint, wind'ng streets, which carried one back to the days of the Renaissance, and which we would gladly have preserved, then made way for the tame and conventionally ornate, but essentially wearisome style which Haussmann applied to those great Parisian thoroughfares.

We cannot be too sure that something of the same kind would not happen again; and, therefore, perhaps, we must not too much lament the unchartered freedom, the unqualified and absolute license which is now enjoyed, because it, at any rate, does preserve a certain measure of variety. And when taste grows better it may be that everyone putting up a building in a street will think a little more than he has hitherto thought of its harmony with the adjoining buildings.

As you know, there is one difference between the condition in London and the condition here. In your American cities, as a rule, the man owns his own land and puts his own house upon it; or even if the builder builds the house upon speculation and afterwards sells it, it is generally not done in large stretches of houses. In London, on the other hand, the existence of large estates, each owned by a great landlord, has led to the erection of long stretches of houses, sometimes perhaps half a quarter of a mile or even a quarter of a mile, all upon some uniform plan. The architect of the estate controls the whole affair, and what is erected follows the designs he suggests or approves. You have not that here, and therefore you see the results in the fact that in London many of our streets belonging to these large estates are exceedingly monotonous, and such streets as Gower Street or Hurley Street, 
for instance, are as dull as can be. Here, and in Washington, in particular, on the other hand, you have the very opposite extreme. Everybody does what is right in his own eyes. $\mathrm{He}$ builds his own house in his own way, and you very often have the most incongruous styles or sizes close together. At the same time you have a certain amount of variety, which on the whole, is better than the dreary uniformity of such a dream of ugliness as Gower Street.

This further thought occurs to me as bearing on the subject, namely, that so far as I know (I hesitate to assert anything positively in the presence of so many specialists and experts) there was never any age until the nineteenth century when people built in so many different styles, side by side. (Applause and laughter.) If you go back to the end of the Middle Ages (for, of course, we have not very many private houses left from the Middle Ages, and comparatively few in England, even from the sixteenth century), it was otherwise. It was otherwise even in the seventeenth and eighteenth centuries. Should I be wrong in saying that in all previous ages of the world, down till about 100 years ago, pretty nearly all the houses erected at the same time were built in something like the same general style? Whether you took the fifteenth, sixteenth, or the seventeenth and first half of the eighteenth century, you would find that the houses that were built about the same time usually followed the same general design and were marked by similar architectural details. I hope this broad statement is not wrong. If it is, I would like to be corrected at once, in order that I may not get any deeper in the mire.

But, speaking as an amateur who has wandered through a great many cities of Europe and Western Asia, that is the general impression a study of the past produces. About the niddle, or rather before the middle, of the nineteenth century we began to be interested in older styles and to attempt to reproduce them. There was a revival of the Pointed Gothic and also of the Romanesque. One architect fancied one style, another another. So men got to building in all sorts of styles, so that you may now see in modern English or American cities houses, or churches, side by side whose architecture em- 
bodies styles of the fourteenth, fifteenth, sixteenth, seventeenth or eighteenth centuries. You may see a City Hall, or a private mansion, in the Colonial, or Georgian style, side by side with a bank imitating the Tudor architecture, or a church in Fifteenth Century Perpendicular Gothic. In the streets of Washington Twelfth Century Romanesque and Eighteenth Century Georgian are constantly challenging one another. Thus we. have a certain grotesqueness and strangeness of effect which did not belong to any preceding architectural age. Now this may pass. It may be that in the twentieth century people will either hit upon a style which is new, or will manage in some way or other so to adjoin buildings to one another as not to make the contrast too startling. It is a common error, to which we are all liable, to assume that the particular merits or faults we observe in our own times are necessarily likely to last. It may be that just as we passed into a new phase in the middle of the nineteenth century, so we should pass out of our present phase into some other in another fifty years. Therefore we need not despair. What we have got to do is to each of us try to cultivate good taste and endeavor to educate the public.

One remark, however, I must make about our English building laws, such as they are, to note a point in which they may deserve to be copied by you. We have laws which prevent the erection of buildings of great height, out of proportion to the width of the street in which they stand. (Applause.) It would not be possible with us to have such skyscrapers as adorn the southern end of Manhattan Island-I say "adorn" because they seem to me to be the most striking as well as novel feature of modern city architecture. If you sail around the south end of Manhattan Island late in the afternoon, when the lights are falling athwart these tremendous piles, and look up at them from about one-fourth or half a mile off to the south, they do constitute one of the most tremendous and awful things that human imagination, or human wealth, or ingenuity, has ever succeeded in planning. You may say it is hideous, but there is a certain grandeur in the hideousness. They seem to me to be fitted to suggest to an imagination like Dante's some gigantic simile, with which might be compared something 
that is outside our own earth. (Laughter and applause.) Let 11, therefore, even in the midst of our horror, admit that they give us a new idea of what architecture might be capable of in the hands of some one who was able to combine these gigantic dimensions with those lines of beauty which at present are wanting in the skyscrapers.

Now, in the interest not so much of beauty as of sanitary requirements, it is not lawful with us, at any rate in London, and I believe the same is true of our other great cities, to erect a building disproportionate to the width of the street in which it stands; and that is a rule which should surely commend itself not only to good taste, but also to considerations of health. It cannot be for anyone's advantage to be obliged to live in a comparatively narrow street, at the bottom of a deep well, from which fresh air and sunlight are so entirely excluded as they are from some streets in New York and Chicago. That surely is a subject to which this Federation might very well direct its attention, and in which you will have a great deal of sympathy even from those who have not yet been educated up to the highest æsthetic standard.

One word more I would like to say upon another subject, in connection, however, with the question of building regulations - it is the use that may be made of beautiful sites. Every traveler through this country must be struck by the facthe is struck by it, of course, in Europe, too, but I want to give you American illustrations-that there are sometimes sites of great natural beauty which are not turned to proper account. (Applause.) Let me begin by frankly confessing the sins of my own country in this matter, in order that you may not think I am too censorious about your country. There is hardly any spot in Europe which is more picturesque and striking, and which is more ennobled by historical associations, than the Castle Rock of Edinburgh. Probably most of you have seen that Castle Rock and you know how from the early days, when the Saxon monarch is said to have erected a rude fortification upon the top of it, down almost to our own time, it has been one of the centers of Scottish history, and you know of how many striking events it was the theater in the sixteenth and seventeenth centuries in Scotland. 
It is the scenic glory of Edinburgh, which is one of the most picturesque capitals of Europe, and one with which many literary memories, as well as historic memories, are intertwined. Now upon the top of Castle Rock there stands one of the ugliest buildings that the wit of man ever devised. It is a marvel to me how it has been possible to allow that hideous erection to stand all this time. It was built as a sort of barracks, and I think at the end of the eighteenth or beginning of the nineteenth century ; and it immediately overshadows and dwarfs one of the most delightful, tiny specimens of Romanesque architecture in Scotland-the Chapel of Queen Margaret. This odious structure completely destroys the architectural effect of the top of Castle Rock; and it does seem a tragic thing that it should be allowed to remain there. I suppose the only good reason that can be given is that it would have to be replaced by something else, and the controversial spirit of the Scotch would be occupied in discussing what style of building should be put in its place and the discussion would never come to an end. Far better destroy it altogether.

Well, there is an instance in order to show that I do not come before you and tell you that we have found perfection and that you ought to follow, because we in Britain ourselves have a great deal to correct and a great deal to regret.

Many years ago I happened to visit the city of St. Paul, Minnesota. There was then a street running along the edge of the great bluff which overlooks the Mississippi River. The street was nothing in itself, the houses were neither better nor worse than the other houses of a western city. What was delightful was the view from the street. Nothing could be imagined more beautiful and effective than its site made it, to those who walked in that street. For something like half a mile the houses had been built upon one side only, leaving the other side open; and you looked from the edge of the bluff over the broad, smiling flood of the Mississippi River beneath, winding in graceful curves through the valley. A mile or two off you saw the opposite bluff, covered with woods, stretching away down to the south; again, with those lovely curves, again with those exquisite woods fringing the water, and with the 
illimitable prairies stretching off beyond the bluff's edge far away to the West. It was worth going hundreds of miles to see that view from the street along the bluff of St. Paul.

The next time I went to the city I found they had built up the other side of that street, and the view from the bluff was entirely gone. Nobody could see the view except the people who looked out of the back windows of the houses on that side of the street; and the main street of St. Paul, instead of being a fascinating and romantic street, with this exquisite view all along it, had become like any other street in any other western city. And yet how small the value of the houses on the side towards the river would have been, and how well worth the while of the city it would have been to have bought up that edge of the bluff and kept the bluff view open for all generations, to be a joy alike to the people of the city and its visitors. (Applause.)

The other day I saw something of the same kind in San Francisco. Nobody who inhabits any other city, I hope, will be offended if I venture to say that the city of San Francisco has got the grandest and noblest site of any city on the North American continent. Many people talk of Quebec and New York, and there are many other picturesque spots, such as Detroit and Kansas. City, but I cannot believe there is any other city which deserves to be compared with the city of San Francisco for situation. Look at the magnificent bay, stretching many, many miles inland, bordered by mountains and studded with islands. Look at noble Tamalpais and its fellows, that rise to the north of the Golden Gate, or at the Golden Gate itself and the immense expanse of the Pacific beyond.

Bombay and Constantinople, Rio de Janeiro and Naples, have been compared with it, but there is really hardly a city in the world fit to be compared with it. Certainly no city is either more finely placed, or has a more delicious air, and surely none more enthrals the imagination than does the city of San Francisco. Now, San Francisco has latterly been spreading north and west. Its people have no doubt done a very admirable thing in taking the large stretch of sandy and waste ground to the west and turning it into a garden and park. But as the 
city spreads northward it has come onto a group of bold, nearly isolated, hills, which look down, on the east to the Bay, and on the north to the Golden Gate, and to the northwest out through the Golden Gate to the Pacific. They rise from the water's edge pretty steeply, to a height of from, speaking roundly, two hundred to three hundred feet. They offer the most superb position that can be imagined for architectural decoration, for fine public buildings, such as a City Hall, a Court House, or for churches, to crown the tops of the hills, while rows of great mercantile offices, or fine private residences, might run in terraces around the slopes, sinking one after another down to the level of the sea. There would be beautiful promenades commanding these views; superb sea and mountain views; and the aspect of the city from the Golden Gate and the Bay and the opposite shores would be altogether noble:

The recent earthquake at San Francisco seemed to give opportunity for taking this land and laying it properly out, and so handling it as to secure the maximum of architectural effect, and to the maximum of beauty to the landscape. Nature had done all she could; Nature had invited the people of San Francisco to make their city worthy of the site she had provided for them. Was it that the people of San Francisco were especially wanting in local or municipal pride? Certainly not. But, somehow or other, nobody stepped forward to do what was needed. The business men of San Francisco were in a great hurry. They had suffered terrible losses and wanted to repair these losses at once. So they ran up buildings in a rough, sudden, hasty way; they lost the opportunity of laying out streets, and, above all, they lost the opportunity of making this wonderful group of hills worthy of the opportunities which Nature had provided for them. I do not know whether this omission can ever be repaired. Perhaps it will not, because the larger the city grows the greater the value of the land and the greater the difficulty of purchasing the land and laying it out for architectural purposes.

One cannot exactly complain of the people-they were suffering from the effects of a great natural catastrophe; they had lost so much money that they were little disposed to incur the cost of great improvement. There was no directing mind to 
say what had ought to be done. I found the most intelligent people deploring what had happened, but they said it was unavoidable. I will do no more than to express the regret which whoever visits the city hereafter will feel. Here there seems to be a subject fit for the deliberation of such a body as this, and one to which you may direct the attention of the American public, in the hope that by familiarizing the body of the people with the ideas you hold, you may at last succeed in bringing about better appreciation of the value of beauty in this land. That is surely the main aim for which your association exists.

You want to make people understand that we are not living here merely for the purposes of commerce and material development; we are living for the purpose of enjoyment, and that among the sources of enjoyment there is none which we ought more to cultivate than the preservation of such beauties as Nature has deigned to give, as even in and around those huge cities which we are unfortunately forced to inhabit. We are laboring in the same cause in England. We have formed societies for the sake of preserving places of natural beauty and historical interest; and also for the sake of endeavoring to improve the architecture of our cities. We have a particular society which I dare say is known to some of you, which has been working assiduously to prevent the defacement of the beauty of the city by advertisements, a form of defacement which is the shame of the nineteenth century to have invented, but which I hope it will have been the glory of the twentieth century to have abolished. (Applause.)

These are things, ladies and gentlemen, after all, which can only be done by permeating the public mind. It is often said, and with truth, "There is no use trying to get legislation in advance of public opinion." You have got to create here, as we have also to create in England, an enlightened public opinion in these matters. It will be a slow business, but many of you will live, no doubt, to see the cause advanced much farther than it is now ; and when you have educated public opinion you will succeed in getting legislatures and city councils to adopt regulations which will secure the objects you have at heart. In all your work, let me say once more, you have the very warmest sympathy from those who are laboring for like ends in European countries and especially in Britain. (Applause.) 
Mr. Glenn Brown, acting secretary, then announced that the Cosmos Club extended to the delegates of the Convention the privilege of its Club house for the period of three days, explaining that the male delegates only were referred to-the club being devoted exclusively to men.

The Chairman next called attention to the fact that the President and Mrs. Taft were to receive the delegates and their families in the East Room of the White House at half past two o'clock, and then said:

The Chairman. For the fine programme of the morning, or for the arrangement of this programme, we are greatly indebted to Mr. William E. Curtis, Mr. A. J. Parsons, Mr. F. D. Millet, and Mr. Glenn Brown, and I feel that we ought to thank them for the work that they have done in arranging so successful a meeting. (Applause.)

There will be a session of the Convention this afternoon at half-past three o'clock in the large hall up-stairs at the top of the hotel.

Is there anything more to come before the meeting?

Mr. EllicotT. In connection with the admirable remarks of the British Ambassador I should like to show a little diagram, which I made-a thing that occurred to me many years ago-the idea of creating a vista in front of St. Peter's in Rome. Everybody probably knows that St. Peter's Church in Rome is approached only through two very miserable streets, but it is quite evident that the great architect who laid out the plan of the church and the peristyle meant something better for the approach to that church. (Holding up diagram.) You will see that these two streets converge and come pretty nearly to a point. There are about three or four small blocks of buildings, of very minor importance, I think, which I have indicated in red, and if these buildings were taken down there would probably be one of the most splendid approaches to one of the greatest buildings in the world, and I think it would be interesting and suitable to suggest to the American Academy in Rome that some little study and thought be given to that object. 
Mr. Marburg. It seems to me that so valuable a suggestion as that of Mr. Ellicott's ought not to be neglected and that it would be well to refer it to a committee of gentlemen, if there is no Committee on Resolutions, with the idea that the society might act upon it later on.

This motion was seconded and carried. The Convention then adjourned until afternoon. 


\section{SECOND SESSION.}

Tuesday Afternoon, May 11, 1909.

In the Banquet Hall, New Willard Hotel, at 3.30 o'clock, Mr. Charles L. Hutchinson in the chair.

The Chairman. It is our intention to begin the sessions of the Convention promptly at the hours named upon the programme. We are a little late this afternoon on account of the delay at the White House. President Taft explained that he was unavoidably detained by a call of the Russian Ambassador.

The Chairman has appointed as members of the Committee on Resolutions: Theodore Marburg, Chairman; H. W. Corbett and Mitchell Carroll, and will ask Mr. Ellicott to kindly refer his matter to that Committee.

This afternoon we are to have a programme as interesting as that of the morning, and when I say as ably handled I am setting a very high standard. The first subject for our consideration is the "Cultivation of Public Taste," and anyone who is interested in the Fine Arts knows Miss Levy, another of those devoted, able women who are doing more than we can tell for the upbuilding of the love of the fine arts in our countryMiss Levy! (Applause.) 
THE CULTIVATION OF THE PUBLIC TASTE.

\section{ADDRESS OF \\ Miss Florence N. Levy.}

Mr. Chairman, Ladies and Gentlemen: It is quite out of place for me to mention, before this audience, the need of cultivating taste or the importance of good taste. It is my purpose to outline briefly what has been done in Europe for the cultivation of taste; to tell you, also, very briefly, some of the work that has been done and is being done in the United States for the cultivation of taste, and then to suggest some of the things that an American Federation of Arts might do to help this movement.

At Mannheim, in September, 1903, there was held a conference of museum authorities, possibly the first of its kind ever held, and certainly the first one that was held in Germany. The purpose of this conference was to discuss ways by which museums might be brought into touch with the working people. The following notes will give some idea of the subjects touched upon at that Congress. The representative from Bremen spoke of the fact that in that city visits to the museums were obligatory on the children of the public schools, and that the children were required to write about what they had seen. From Vienna collections are circulated through the towns of Austria that have no museums, and lectures, in connection with these exhibitions, are given by teachers at the high schools. The Kingdom of Bavaria encourages the formation of small local museums of art, connected with the life of the people. In Paris there is a Musée Pédégogique which circulates annually 40,000 lectures, with lantern slides. In London the Victoria and Albert Museum, better known as the South Kensington, is the center of that wonderful system of circulating exhibitions, chiefly of industrial art, which goes to some 350 art schools and some 90 county museums. Munich prides itself on its industrial schools and its industrial museums.

Coming to our country I would call your attention first to the marvelous growth of interest in art during the past fifteen years, that is, since the World's Fair in Chicago, in 1893. 
It is true that the Pennsylvania Academy of Fine Arts has already celebrated its centennial, and that the National Academy of Design is only within ten years of its hundredth anniversary, but it is only recently that there has been this wide interest in the training of taste. We have had good artistswe have them today, but not a sufficiently large, appreciative public. This very meeting shows the interest that is being taken. At the present time there is being held in Philadelphia a three days' convention of the museums of the countrythe American Association of Museums; and the Art Museums are federated through that association, although the art section has done no active work. The art teachers have their federation-there is the Eastern Art and Manual Training Teachers Association, that has just closed its two days' convention in Pittsburgh; and the Western Art and Manual Training Teachers Association, which will hold its convention shortly in Los Angeles.

All this is simply to show that we have passed the stage when art meant only the easel picture in the gilt frame; we have come to the time when art in life-art and life closely related-mean very much more to us. There is the keener appreciation of beauty on all sides, keener appreciation of nature which comes very often through training in art. It lends itself to producing better citizenship-better men and women and happier lives.

A practical example of the way this influence is felt will be shown by some of the experiences of a little group of students in the Technical School for Girls which I was interested in last summer. On one occasion Dr. John Quincy Adams, the secretary of the Art Commission of New York, spoke to them on "Art and Life." $\mathrm{He}$ had a Chippendale chair on the platform, and a modern gilt one. He compared and contrasted these chairs with personal characteristicsshowed the sterling qualities of the Chippendale chairs and the deceit of the veneer, the paint and the lack of strength in the gilt chair. About three hundred girls heard this talk; I could not manage quite as many as that out of doors-but about twelve or fifteen went with me each Wednesday to see some points of artistic interest in New York. One day one 
of the girls suddenly remarked, "O, there goes a gilt chair!" It was just the type of woman that corresponded to the gilt chair. (Laughter.) Another day this same group of girls was with me in Union Square, and we were looking at the statue of Lafayette. Those of you who know Union Square, know that there are other statues there, and also that it is a great center for the little newsboys. A tiny little one, just a bit taller than this desk, joined us. He was very much interested. After we had walked around and tried to see which was the best point of view, I asked him whether he had ever noticed that statue before. "No, but I know the Washington and the Lincoln, and now I have three friends here," he replied.

Just one more of these experiences of the girls. We were on our way down town to Battery Park and took the subway. When we got out of the subway I made them stop suddenly and look up at the sky. One of the girls said, "I never knew that it was so beautiful, I never knew it was so blue." Now, if we can give them that which will help to make their lives happier we shall have accomplished much-if when they come out from the subway they can see a bit of beauty in the sky, surely they will be in better condition for their day's work.

Twenty years ago George Brown Goode, speaking at the Brooklyn Institute of Arts and Sciences, predicted that in 1914 the United States would lead the world in the educational value of its museums. He reasoned that the first great exposition was held in London in 1851 and that in thirty-eight years the South Kensington Museum had reached its wonderful development. Taking, therefore, the first exposition in this country, the Philadelphia Centennial of 1876, he allowed the same number of years for our development along these lines. "The Museum of the Past," said Mr. Goode, "must be transformed from a cemetery of bric-a-brac into a nursery of living thought. The museum of the future must stand side by side with the library and the laboratory as a part of the teaching equipment of the college and the university, and cooperate with the public library as one of the principal agencies for the eniightenment of the people." 
The value of a museum's collection should not be estimated by the money spent nor by the size of its catalogue, but by the rsthetic growth of the community, and while some of our museums have been little more than storage warehouses, they are beginning to realize that they need an active propagandathey have work to do in teaching the teachers first, in order that, in turn, these teachers may carry it to our young people in the schools.

Without reference, then, to the actual value of the collections in any of our museums, I would like to summarize what these museums are doing. Boston's Museum of Fine Arts was the first to give active and systematic instruction to grade teachers, and it is constantly increasing its work along that line; lectures in the galleries-direct help to the teachers; and it has the largest collection of photographs for reference.

Chicago's Art Institute has the best lecture hall, the finest library building, and the only library class room. I am leaving out of consideration altogether the question of conduct of the art schools in connection with the museums. That is another phase. That is the training of the artist, and I am trying to touch merely on what our museums are doing to cultivate taste in the general public.

Detroit has the largest collection of lantern slides, and has conducted the most successful course of lectures for the public.

Toledo has been most successful in carrying out a systematic plan of co-operation between the public schools and the museum. Every child in the elementary public schools of Toledo visited the museums last winter, and heard a talk on "Egyptian Art," and handled objects some 3,000 years old. That was made possible by the fact that the Director gave a twenty-minute talk in the Egyptian Gallery at 2 o'clock every day of the school term, and twenty-two thousand children heard that talk. This year he has taken up Greek Art in the same way, and every child in Toledo's public schools will know from direct contact with objects of Greek Art something about that phase of art development.

Pittsburg is the only city which has systematically circulated large photographs of pictures in its collections. There the Art Department of the Carnegie Institute has framed three sets of large carbon reproductions of the best paintings 
in its permanent collection, and these go from school to school, remaining about a month at each school.

New York, we will have to acknowledge, has been asleep, but when New York wakes up it generally gets far ahead of the other cities. The Metropolitan Museum of Art has been undergoing changes for the last three years. It has recently started the educational work by having a small class room. It is lending lantern slides, and it has a guide who is kept very busy taking people through the museum. But there is more coming. The new lecture hall is completed and will be opened for use next winter, the new library is almost finished, and there are other innovations under consideration.

The Brooklyn Institute of Arts and Sciences has the best organized courses of lectures and its weekly bulletins keep its. thousands of members in touch with its many activities. This does not by any means include all that has been done for the cultivation of taste in the United States. It would take up a great deal more time than you would give me to cover that field.

The various societies of artists are, we must acknowledge, organized chiefly to show the work of members, but, at the same time, they have been a great power for training in taste.

One of the strongest influences along this line is the municipal art society or municipal art league, or civic art league, where the combination of layman and artists working together for the good of their city, for the beautifying of their home surroundings, has done so much to cultivate public taste. The Women's Clubs dot this country very thickly. They are well federated in city federations, State federations and a national federation. The art societies could well use them as models. From the first they studied the history of art and some years. ago this was considered all that was necessary. When they had an art day, a member would be asked to write about Raphael, or some other artist, would look it up in an. encyclopedia, and read what had been copied. It meant nothing to them; they had never seen a painting by Raphael; they could not understand or appreciate. But lately more practical work has been done. They have circulated 
groups of paintings by some of our best American artists, and they have also circulated good copies of noted paintings. There are, I believe, at present three groups traveling. They are in such demand in the smaller cities that although the exhibition can remain only three days in a town before it is sent on to the next nearest point, there was, a short time ago, a waiting list of 122 towns asking for collections of this kind. The full credit for carrying on this work is due to Mrs. John Sherwood, of Chicago.

The artists also have circulating exhibitions. The Society of Western Artists sends one regularly to the museums of Chicago, St. Louis, Cincinnati, Columbus and Indianapolis. There is also what is known as the Mid-West Circuit, which sends pictures to Lincoln, Kansas City and Lawrence, Kansas. The New York Water Color Club and the American Water Color Society also send out groups of their work.

Then there are State art societies. Perhaps some of you will be surprised to hear that the first State art society was founded eight years ago in Utah. Minnesota followed next, and Washington was the third State. Each of these State art societies circulates pictures, and the industrial art crafts in its own State, awards prizes and makes purchases for a State Art Gallery.

The Craft Societies for the development of the arts and crafts and for manual training have grown wonderfully in number in the past few years. I saw a statement in print a few days ago that there was something like two thousand craft societies in the United States. I have been unable to locate even one-tenth of that number, that is, to get actual data and the names of officers from them; but there are very, very many, and they are exerting a great influence. Some of this influence is not quite in the right direction. It is not necessary that we should have hand-made jewelry, poor in design and rather clumsy in execution. It is necessary that we should have well-trained cabinet makers, wall paper designers, potters, etc., and it is along the practical side that we need a great deal of help.

Of all the influences now being exerted, however, the strongest is through the public schools. There you get in 
touch with thousands of children at the age when they can be most easily influenced. Do you realize that in New York city there are 604 elementary schools, with over half a million children, and those children are under the influence of the school every day for ten months of the year. Results depend practically upon the individual teachers here, and it devolves upon organizations such as this to help the teachers. Art is only one phase of their work, but they grasp eagerly every little bit of assistance that is given to them. The co-relation of the departments of art and manual training in the public schools has led to much better work, because designing is done for a specific and direct purpose, and when good forms have been made in the shops they are decorated appropriatelynot ruined by the decoration.

School Art Leagues have been organized in many cities, their chief purpose being to aid in the decoration of the school buildings by presenting pictures and casts. The Art League of the Public Education Association of New York has gone a step further and awards a bronze medal for "Fine Craftsmanship" in each of the workshops of the elementary public schools.

An art class was formed a few years ago at the Young Men's Christian Association for instruction to the salesmen of the New York department stores. At first this was rather an experiment, but it has proved a great success. These men vary in age from sixteen to sixty, and they are a most interested and interesting group. Out of this class has grown what is known as the "Art in Trades Club." As an example of the influence of this training, suppose that you go to a shop and want to buy wall paper. You have a sample of carpet, and say, "I want something that will go with this carpet"you do not say "harmonize"-for in the past the salesman knew nothing about that. Once upon a time he would have pulled out the first roll of wall paper that came to hand. If, however, he knows something about color and harmony and fitness he will bring out the right thing. It then becomes simply a choice between two or three, any one of which would be good. You see the enormous influence that can 
thus be brought directly into the homes of the people through such training in taste.

And now, what can an American Federation of Art societies do to help this? First and foremost it can serve as a clearinghouse, where the experience of one organization can be handed on to the next. A new organization, the one that is struggling and feeling its way will not have to go through all the trials and tribulations that some other society has had when it began its work. It can have expert advice from those who have gone through these same trials. It can have a lecture bureau that would furnish typewritten lectures and lantern slides, or would recommend available lecturers. And here let me dwell once more on the need, not of history of art, but helping to see, and for that no written work can help. It must be the personal contact (Applause); and it is the "helping to see" that will in the end create that appreciative audience which we lack so much at present.

The circulation of exhibitions of the Fine and the Applied Arts in the smaller towns-not where they have museums, but where the library can serve as the center, or the high school. This has been tried successfully in Newark, where the library was the art center of the city until within a month, when an art gallery was incorporated.

In Richmond, Indiana, for ten years the school board has given the use of the high school room for the first week in June, and the school board has annually appropriated $\$ 100$ towards the expense of the exhibition. The quality of this exhibition has during the last few years been equal to any in New York, Philadelphia or Washington.

In Watertown, N. Y., the library has served as the center, and there a new plan was tried and successfully worked out. An admission fee was charged of ten cents. This admission entitled the visitor to a vote, and the picture that received the highest number of votes was purchased, and became a part of the municipal art gallery. Now that has a two-fold purpose: First, it makes each one that comes to the exhibition study the pictures, look around and compare and make up his mind which picture he considered the best before he casts his vote. And second, it keeps the picture in the city and 
makes each visitor feel that he has a personal interest in it, for his vote helped to buy it.

The Federation's central bureau would be of the greatest help in preparing for international expositions. The artists who have worked on committees of that kind know what it means to start right from the beginning and collect all the data; and that is done every time, because there is always a new group. Anybody who has gone through it once never wants to do it again! In France there is a permanent organization. It is true that they know that they are going to have an exposition there every eleven years, and as soon as one is over they begin preparations for the next. We need something of that kind here; it would save time and money, and it would be done very much better.

But, above all, we need more industrial art schools and industrial art museums. There you come to the practical side. Why is it we have to get our most beautiful objects from abroad? Because we have not the workers here. The only well-organized industrial art school that we have is the school in Philadelphia. Beyond that we have a few, but they are not up to the standard that we would wish to see. In New York, Cooper Union is the nearest approach, and yet is far from being a real industrial art school. Yet Cooper Union has a long waiting list. That in itself again proves the need. A young Italian who wanted to learn modeling waited years before he could have his application accepted at Cooper Union. As soon as he was registered as a student he put the names of his two brothers, eight and ten years of age, on the waiting list, in order that, as he said, "they need not lose their best years."

If art, is doing a thing well, then the training in taste is the appreciation of work well done, and really it is time that we combine the industrial spirit of the age with that idealism which is in the American character. We are usually considered a purely commercial people, but there is an idealism in the American character that tries to express itself and that should be recognized and combined with the utilitarian.

The country's art to develop needs the right soil and it needs the right cultivation, and just as Burbank works out his 
theories with plants, so can good taste be cultivated throughout the United States. (Applause.)

Being asked to give an account of the exhibition of Spanish paintings held in New York last winter, the popularity of which had been a surprise to all, Miss Levy said:

There was in that exhibition of Spanish art a freedom and fullness of life that attracted attention, because it was very different from many of the exhibitions to which our public was accustomed. But I think that the crowds were due a great deal to the human inclination to follow. I was there the first day, and the second day, and I assure you there were very few people, but it became rather a fad, and when people realized that they had to stand in line and take their turn many went out of curiosity. The pictures were beautiful, but there are four of them now in the Metropolitan Museum, and I do not think four people a day go to see them.

The Chairman. The largest attendance that we ever had at the Art Institute at Chicago was occasioned by a regiment of United States soldiers camping upon the Lake Front adjoining our building to suppress a riot. (Laughter.) If Mr. French, the director of the Art Museum, were here-he will be tomorrow-I think he would be on his feet to tell Miss Levy that last year in the schools of the Art Institute 1,100 of the teachers of our public schools took a course in drawing and painting.

Miss Levy's paper has suggested a great many things to me, and among other things it suggested the fact that there is a commercial value to art that we might possibly bring to the attention of those who are sordid minded. And it reminds me of a story that I have told so many times in Chicago that I dare not tell it there again, but possibly I may venture to tell it here,-a story illustrating the value of an art museum in a city so commercial as Chicago. When we were occupying the old building Mr. French happened one day to be passing the doorkeeper, when he heard some one say, "Have you got Niobe here?" Attracted by the question, Mr. French went up an! 
said, "What did you say?" The man replied, "I said, have you got Niobe here?" Well it happened that we had just received three or four casts of a number of groups, and Mr. French said, "Yes." The fellow then said, "I want to see her." Mr. French said, "Are you interested in art?" "No, have I got to say why I want to see her to get in?" Mr. French said, "Not at all, by paying twenty-five cents admission you may come and go as you please, but I thought if you were especially interested in the study of art that I should be glad to admit you free." The man pulled up a box, and taking out a bottle, said, "I am about to peddle this celebrated Niobe wash for removing stains, and before I set about my business I thought I would like to know something about Niobe." (Laughter.) Mr. French took him in and introduced him to one or two of our custodians and then asked him if he would be interested to read something in reference to Niobe. He said he would, so Mr. French took the man to the library and gave him two or three books. He spent an hour there and on his way out stopped to thank Mr. French, who said, "Have you found what you wanted?" The man replied, "Yes, but I do not know what they wanted to kill Niobe for-do you know?" We had to admit our ignorance. (Laughter.) The sequel is even funnier than the original story. I told that story soon afterwards at a public dinner in Chicago, where I was trying to establish the fact that even in a commercial city the Art Museum might be of interest, and the story was reported and copied quite extensively throughout the country.

Two years afterwards a man came into my office and said, "Are you Mr. Hutchinson-are you the president of the Art Institute?" I admitted I was. He said, "I am the man that you told the Niobe story about." I thought I was going to be called to account, but instead he said, "Well, I came in to thank your. You do not know how much good that story has done me. It is the best advertising I ever had." (Laughter.) That was just before Christmas, and he added, "I would like to show my appreciation. Would you accept as a token of my esteem and obligation a couple of bottles of the wash?" (Laughter.) Those are the only gratuities that I have ever received on account of my connection with the Art Institute of 
Chicago. (Renewed laughter.) So, you see, there are reasons why an Art Museum should be maintained from a purely commercial standpoint.

We are to listen now to a paper on "Art in the Public Schools," a most important phase of our subject, and we are very fortunate in having the United States Commissioner of Education, the Hon. Elmer Ellsworth Brown, to address us upon this very interesting topic. (Applause.) 
ART IN THE PUBLIC SCHOOLS.

ADDRESS OF

Hon. Elmer Ellsworth Brown,

United States Commissioner of Education.

Mr. Chairman, Ladies and Gentlemen: I am very much indebted to Miss Levy for the delightful way in which she has told some part of the story of the relationship of the public schools to Art, or the relationship of Art to the public schools. I have listened with the greatest interest to the accounts that she has given, touching here and there upon some of the beginnings that have been made in the way of bringing the public schools into some sort of sympathetic relation with the art museums and the workers in the fine arts.

In addition to those things that she has spoken of, we commonly think, in connection with this topic, of such matters as the placing of works of art in the public schools, which has been done, as all of you know, very extensively in recent years; a movement that began back in the seventies and eighties, and has come to be of real significance in our education; or we think of the work that has been done in drawing and design, in the use of colors and in modeling, in connection with systematic instruction in art, especially in our elementary schools. All of that is significant of a real movement, a movement that has made certainly significant progress within the past twenty years-within the past ten years, we may say, in particular. But I should like to speak, this afternoon, of the case of art in its relation to our public education, where it finds its deeper grounding - the real, significant center, as it seems to me, of our consideration of this whole subject.

It is evident that our modern education is in a definite and conscious alliance with natural science. There is nothing more characteristic of modern education than this fact. It is a significant fact. It means that there is a difference between the education of this present time and the education of earlier times. It means a change in our civilization. Our 
schools are in a positive alliance with the natural science of this age, and a large part of the significance of modern education is found in this fact-a large part of its difference from the education of earlier times, a large part of its adaptation to the actual needs of our own time. The thing that I wish to say is simply this, that we are coming to see with some degree of clearness that for the very safety of this alliance between science and education, there must be another alliance, equally definite, equally profound-an alliance between our modern education and modern art.

The education of any time is largely made by the institutions and the movements with which it comes into working connection. You know how in the history of education that working connection between the schools and the institutions of religion was the significant and dominant fact for so many generations. It is not to be supposed that that alliance has wholly lost its significance for the present and the future. But the time came when it was absolutely necessary that the schools should come into definite and positive alliance with the scientific movement, if they were to fill their place in the modern world. It is equally clear that a time is coming, if the time has not already come, when an equally definite, positive, frank, and open alliance between education and art must be a significant fact of our educational life.

This is a generality, of course, but I do not think it exaggerates, and I think that it is significant for the actual work-aday life of the schools. I should like to invite you to look into it a little further and see the significance of it as it appeals to me. Let us take the alliance of the schools with modern science, and see what it has done for our education. It has given to our education a certain concreteness, a certain tangible and practical character, which it lacked before. It has given a certain objective sincerity to the work of education that could not be got in the same way from any other connection. It has brought into the thought of our time some sort of appreciation of the organization of the external world. It has given us a hold upon the things that make for human comfort and make for human convenience. 
The alliance of education with science works for other things besides comfort and convenience. To those who go deeply into that relationship, it works for the highest things in the intellectual life; and it has tremendous significance for the moral life.

The most obvious thing to the great majority of our people is the fact that scientific education has to do with the increase of human convenience and human comfort. For that very reason this thing that is so absolutely essential and is, in some respects, the highest and the finest thing in our modern education, may frankly be admitted to be a thing that is attended with danger. It is attended with a danger of the subtlest materialism. There can be no doubt that this science must be supplemented by something else, if it is to escape that subtle danger of materialism, a danger that is perhaps more serious in the case of those whom it affects least grossly-in the case of those whom it affects upon the most spiritual side.

Our science, as we teach it in the schools, lays stress such as no earlier education could lay, upon the ability of the present age and the ability of the single individual to put things to the test. Our knowledge is to be verified now and here, not by a slow process, but by an immediate process. It is to be verified on the spot. We come, accordingly, to have only incidental care for the slow making of human thought and human character, through the ages, because we have so much greater interest in the discovery of natural laws which can be worked out right here in this laboratory, by this single man. We need, for the sake of our common humanity, to have a new emphasis upon those things that cannot be done on the spot. (Applause.)

We need a new insistence upon those things which can be tested and verified and determined only in the long course of human experience, of racial experience, otherwise we tend to isolate ourselves and become simply crumbling units, having only a loose connection one with another in an intense individualism. We need to acquire a new respect for those values that only time can reveal, and that is what art has to give to us. It is to give to us a new appreciation of things that are old, of things that are capable of standing the test of time. 
It is to correct that modern danger of valuing things in proportion as they are new.

This is only the slightest intimation of the nature of this new alliance, which I am convinced our modern education must enter into. It is the alliance that is immediately before us. There are only one or two things more that I should like to suggest concerning it.

The first thing of all, to accomplish, apparently, is that we shall learn to take art more seriously. We still treat it as a trivial thing. Our people as a whole regard it as a bit of embroidery upon the real garment of our civilization, as having nothing to do with the substance of our civilization. It is an appendage; it is a something that can be sufficiently considered at odd times. In our institutions of education we have not yet begun to treat the subject of art, or, let us say, the subject of the arts, with that seriousness which is characteristic of our treatment of the sciences. We must not be satisfied to have the arts appear simply as ornaments upon our educational programme. We must look for that close concatenation, that close organization of the art side of our courses of instruction, which we know to be absolutely indispensable upon the science side.

At the present time we have in our lower schools, in our secondary schools, in our universities, some teaching of music. But music is one of the arts that becomes most easily isolated, or that overcomes its isolation with the greatest difficulty. We need to have our teaching of music brought into closer relation with our teaching of literature,-our teaching of literature as a fine art,-we shall have to take it with more seriousness. The tendency of the present time, let it be said, in all frankness-not an exclusive but a dominant tendency,-is to take our studies of literature seriously only when they can be put into the form of a science. We shall learn to take our study of literary art seriously as an art.

We shall learn to take with equal seriousness our study of the plastic arts; our study of the arts of color, of design. And these too are to be worked out into their consecutive courses of study, as if they were of equal importance with the sciences. 
There has been some reference made to the fact that the study of art has commercial value. It is important that it has such value, because that fact renders it possible for us to get some consideration of its claims in quarters where it would not otherwise be considered. The time is coming, I take it, when that commercial value of art will become much more clear and important in the minds of men. The objects of convenience and comfort that our science has taught us to make -the things that we have patented in our Patent Office-these objects we are making for ourselves and are selling to all of the world. But with every decade it becomes more difficult to sell them to the rest of the world, simply because of comfort and convenience, if, at the same time, they offend against the sense of fitness and beauty. This tendency is certain to go on increasing until it will become absolutely necessary, for our success in the markets of the world, that we shall pay thought to the side of beauty, that is, that we pay thought to the spiritual side of the things that we wish to sell. We shall be forced to take such an interest in the spiritual side of things. If there were no other point of view from which this new alliance of education with art were to be urged, it might be urged from this point of view, that the tendency of the modern times is to discount any catering to our comfort and convenience which does not at the sametime recognize the fact that we have spiritual tastes. (Applause.)

The Chairman. There is in Chicago, and I wish it were represented here, a society of ladies called The Public School Art Society. Most of its members are ladies of society, and it has been taking one, two or three of our public schools each. year and converting some of them from barracks to homes. The board of education, I won't say generously, because they get much more than value received-agrees to tint the wallsallows the ladies to have the rooms decorated simply, as they desire-the board of education pays for this part of the work. Then the ladies raise money by voluntary contribution and hang the walls with pictures, selected with rare taste, and put in casts, or sculptures, or other works of art, and the amount 
of good that that little society has done in Chicago during the ten years of its existence can scarcely be estimated. I wish it were here to make a report, for it has done wonderful work in an exceedingly practical way, in bringing good things to the daily attention of these particular school children.

Mr. W. L. HARris. Mr. Chairman, I have in my hand here, as we are giving personal experiences, a medal which is being given in the crafts shops of the public schools of New York. Possibly Miss Levy, who has a fund of information on such subjects, might be able to tell us more about it (handing the medal to the Chairman).

The Chairman. Who designed it?

Mr. Harris. Victor D. Brenner.

The Chairman. How is it given, Miss Levy?

Miss Levy. It is given in the work shops-the craft work shops of the public schools; one in each of the 164 work shops of the New York public schools, each term, to the best piece of work turned out.

The Chairman (examining it). I think Mr. Brenner must have been inspired by the occasion, for it is one of the best pieces of work I think he has ever done.

Miss Levy. We have just had a request from the shop teachers to have large plaster casts of this medal put in each shop as an incentive.

The Chairman. I think you will have a request from the Public School Art Society of Chicago for several of those casts.

Mrs. Robert T. Hill. Might I say that in Washington, under the inspiration of Mrs. Sherwood, of Chicago, a League for the Decoration of the Public Schools has been founded, and the President, Mrs. Chas. W. Richardson, is here, willing, I am sure, to answer any questions.

The Chairman. We will be very glad to hear anything you have to say on the subject, Mrs. Richardson.

Mrs. Chas. W. Richardson. Our society has been in existence such a short time that I have not very much to tell.

Last fall we had a meeting of a few ladies, and we decided to organize a League along the same lines as those in other cities. In February we issued an appeal, in response to which 
we have received over $\$ 500$. We have now 212 Associate Members, contributing a dollar annually; 10 life members, giving $\$ 25$ each, and five contributing chapters, giving $\$ 10$ annually. During the coming summer two schools are to be decorated, one wholly and one partially, but Miss Temple, the chairman of the decoration committee, is here and will tell you of that part of the work.

The Chairman. Will Miss Temple say a word to us?

Miss Grace Lincoln Temple. I can only say that as Mrs. Richardson has told you, we have this spring selected one school in which we will confine our main interest, and that we hope to give a little attention to one other. We thought it better to concentrate our interest in these rather than spread it over several, at the outset-that they might serve as examples. We hope that by another year there will be more to tell at a Convention of this kind.

Mr. A. E. Albright. I think perhaps it might be of interest to you if $I$ were to unfold a litle plan that we have put into operation in Chicago-a plan for exhibiting original paintings in the public schools. We asked the school board of Chicago, last summer, if it would consider a proposition to exhibit in the public schools of Chicago a hundred pictures by Chicago artists, and we asked if it would bear the expense of conveying them from one school to another, hanging them in the schools and taking care of the clerical part that would be necessary to manage such an exhibition; and to our surprise the board consented. We collected a hundred pictures and we divided them into five groups of twenty each. These little groups were made to represent as many painters as possible, there being one picture by one artist in each group; therefore, one person might send five, if he or she chose, and be represented in five divisions. We called these divisions $A, B, C, D$, and $E$, and the school board of Chicago packed them in their wagon, hauled them to the schools and hung them on the walls, each school keeping a group for four weeks.

So we have with this collection of a hundred pictures five exhibitions a month, fifty exhibitions in ten months, and an average daily attendance of five thousand people of Chicago, 
besides the number of teachers in the schools, which would probably average twenty, at least. We have heard from the different schools about these exhibitions, and they have been wonderfully well received. The pupils have learned to know the names of the artists, and they have gone to the Art Institute and looked through the galleries to find the picture by the artists that were represented in these exhibitions. I want to say that we made the standard of the exhibition as high as we could, by requiring that each picture submitted should have been received for some standard exhibition by a jury. Therefore, the pictures were as good as could be had, and we endeavored in each group to have landscapes, figure paintings and portraits, as far as it was possible. It would take five years for this little collection of a hundred pictures to make the complete rounds of the Chicago public schools. Should the different schools ask for one division after the other, A, $B, C, D$, and $E$, it would take twenty-five years to cover the public schools of Chicago alone. (Applause.)

Miss Levy. May I ask one question of Mr. Albright? All of our ideas on school room work in New York-or at least many of them-have come from Chicago, and I should like one more, please. Where do you hang your pictures in the schools?

Mr. Albright. First in the class rooms, changing them from week to week, even sometimes from day to day, and finally in the hall, the last week, when the parents are invited to see them. (Applause.)

The Chairman. I have here a letter which reads: "Through you, Mrs. Vinnie Ream Hoxie invites the officers of the Art Convention, and members, to visit her studio and inspect a statue that she is making for the State of Iowa." The studio is $1632 \mathrm{~K}$ Street.

$\mathrm{I}$ also wish to remind you that tonight we are invited to a reception which is tendered the delegates and their families by Mr. Hennen Jennings, the vice-president of the National Society of the Fine Arts, at his residence, 2221 Massachusetts Avenue, from 9.30 to 11.30 o'clock.

Is there any other business to come before us? 
Mr. Henry Read. Mr. Chairman: I would like to make a few remarks, suggested by Miss Levy's paper. At first I hesitated, but the address by the Commissioner of Education has given me courage.

With reference to the revival of interest in art-craftsmanship, and also with reference to the position of art in education, it seems to me our attention might well be directed to tendencies that are not altogether in the right direction. In both cases they might be classed under the head of an inclination to dilettante treatment of art. If there is one thing for which art stands, or ought to stand, it is simplicity and honesty of purpose. Let me illustrate what I mean. In the course of my professional life I have been brought in contact with so many phases of the relation existing between art and life that I have had, perhaps, unusual opportunities for observation and reflection. In the matter of craftsmanship I have been closely associated with skilled workmen able to distinguish between intelligent labor and the mere machine work that crushes the life out of so many, and among them I find an amused contempt for art-craftsmanship. It is looked upon as a society fad. We all know that art, like every other activity of life, has its fads, but it is most unfortunate that this movement should touch so lightly the men it should influence the most. If I go to an exhibition I see few of our actual workers represented there. They say it is not worth while-it will not lastthat modern commercial and technical methods are hostile to personal individuality. Surely this is a serious outlook. The tendency is to regard art-craftsmanship as a harmless amusement, good in its way, to be encouraged as far as possible, but to be passed by when it comes to business.

Let me go on to speak of education. In this I have had considerable experience, both here and in Europe. During the past fifteen years I have been director of an art school, and, let me tell you frankly, I would rather have an untrained child enter that school than one who has received the present average training of the public schools. This is a sweeping statement, and, of course, like all sweeping statements, is apt to be very unjust. Let me see if I can explain it. I once examined carefully examples of public school work from one of the great cities of this country. It was graded work, be- 
ginning with the kindergarten and ending with the high school. I tried to analyze and understand it. The conclusion I came to was this: that other things being equal, the work in proportion to the powers of the pupil deteriorated from the primary grades to the end of the school education. Of course, I do not mean that there was no progress so far as actual examples of work were concerned-I do mean that the development of art power did not correspond with the growing capacity of the child. In the early years of life, expression by means of speech, and expression by means of drawing, are more nearly on the same level. Although conditions which need not be discussed here, tend to develop the one and hinder the other, education emphasizes the difference. This I think is due to two causes. One is, that no sufficient distinction is recognized between the definite aim of cultivating the power of drawing by training the eye and the hand, and the subsequent use of that power in nature study, history, illustration, and some other subjects. We know that with increase of pressure upon the school curriculum, thoroughness is too often sacrificed to superficiality, and one result is that a child's mind, after a few years of current public school art education, is left in a state of chaos. It has a few ideas about decoration, a few ideas about illustration, a few ideas about the history of art; it has caught hold of a few art expressions, but for any practical purpose in the battle of life its powers are nil.

Let me speak of the second cause. I will make another sweeping assertion, and although there are brilliant exceptions to the rule, I will say that the average public school teacher has received no adequate training in art, or proper conception of what art teaching should be in the training of the child. It may seem a harsh thing to say, but I look with misgiving upon a public school teacher who comes into my school for further art training.

These are not pleasant matters to dwell upon, but I believe that outspoken words are the best, and we are far more likely to remedy an evil by acknowledging it, than by crying, "Peace, peace; when there is no peace."

The Convention then adjourned until the following morning. 


\section{THIRD SESSION.}

Wednesday Morning, May 12, 1909.

At 10.11 o'clock the Convention was called to order by $\mathrm{Mr}$. Charles L. Hutchinson, in the Banquet Hall of the New Willard Hotel.

The Chairman. We open the meeting today by considering "Common Sense in Decoration and Craftsmanship," upon which subject Mr. Royal Cortissoz, who needs no introduction to this audience, will address us.

\section{COMMON SENSE IN DECORATION AND CRAFTS- MANSHIP.}

\section{ADDRESS OF}

Mr. Royal Cortissoz.

Mr. Chairman, Ladies and Gentlemen: The purpose of this convention is nothing if not practical. A national federation of art societies is useless if it does not increase the every-day effectiveness of those societies. The whole point of these proceedings, I take it, is that we want more art in this country and we want it to be better and better art every year. Will we get it by dreaming dreams? Yes, but we'll get it quicker if we also use common sense. We are supposed to have a lot of that in our national makeup, but are we not disposed to confine its exercise to what we call the practical affairs of life, and to think of the artist as a person dwelling in an ivory tower, creating beautiful things and leaving common sense to the business folk outside? We go further than that. When we talk of giving the artist something to do, something apart from the painting of an easel picture, in nine cases out of ten we talk of his doing something "monumental," and, on the whole, rather costly. We are building a new State house or a new city hall and we decide to decorate it on an heroic scale. 
We go to one of our noted mural painters and we pay him a round sum to produce a large allegorical composition, which the public then comes in to admire. Surely this is all very fine and desirable. No one in his senses could regret this movement, which is doing so much to adorn our public buildings; no one could wish it to stop. But does not common sense suggest that if we cannot afford an heroic decorationand that is often the case-we should compromise on one less ambitious? We do not do so half often enough, and the result is that hundreds of our buildings lack the beauty that painters might add to them, and a large number of our artists lack the work which they need and which they are competent to do.

It is worth while to reflect for a moment on the lesson to be drawn here from the past. In the Italian Renaissance, the period which, perhaps, more than any other, is rich in lessons for us, the artists and the public or private persons who employed them were intensely practical. They did not regard mural decoration as necessarily an affair of composition on the grand scale. They knew that very often it was wisest to let it mean nothing more than a small panel, and often, too, they dismissed altogether from their minds the idea of filling a given space with a strictly pictorial decoration. They filled it, instead, with dainty arabesques, with floral motives, with conventionalized ornament. And the greatest artists of those days were content, on occasion, to design such formal schemes. Raphael, who made those stupendous decorations in the Vatican, designed also the arabesques which made the famous loggia in the same building one of the most beautiful things in the world. Leonardo, who could paint the Mona Lisa, could also design a pattern of interlacing leafage for a ceiling in the Castello at Milan. Now, why do we not more frequently follow the example of that time? We have, happily, begun to do so, and there is one artist in this country, James Wall Finn, who is doing very important work in this direction.

But there still remains much to be done in demonstrating to the people of the United States that this kind of decoration is as desirable, because it is as artistic, as the monumental kind. That is where our common sense should come in. If we cannot 
spend $\$ 5,000$ on a large symbolical decoration to fill the arch over the judges' bench in our court room, let us spend $\$ 500$ on the simple decoration of the room in flat tints and with a few arabesques here and there, and let us make that decoration worth while by getting an artist to do it, not the house painter whom we ordinarily think is the man for the job. We have got into a queer way of thinking that there is nothing between the full-dress performance of the stately mural decorator and the commonplace stencil of the journeyman who will put a room in shape by day's work. There are, of course, any number of interesting and charming effects to be developed between those two extremes, if only we would use common sense and make practical use of the modest opportunities that lie all around us, and employ the talent that is everywhere to be found.

As it is with painting so it is with sculpture. We are fond of erecting statues in our public squares. We set a good many of them every year in front of our public buildings or on the buildings themselves. It is a splendid thing that we should do this, but what of our architectural sculpture generally, the ornamental details in stone or terra cotta which may not be individually so conspicuous as a statue but which are actually of immense importance to the beauty of a building? Look around you in any city and you will see that even on the façades of some of our most imposing edifices this work is without any special character, without any artistic value. Why is it? Because we do not use common sense. Our greatest sculptors are rightly kept busy on statues. Why does it not occur to us to occupy their clever juniors on these details? In the Renaissance such work was not always left to the journeyman. Go into the old palace at Urbino, into the Certosa at Pavia, or into any other of a hundred buildings in Italy. You will see door frames and mantelpieces that were carved by sculptors, by artists in the fullest sense of the term.

Now and then, happily, we do secure something of this sort. I recall that not long ago an architect with whom I am acquainted decided that a decorative detail, a wreath, which he wished to have executed in stone, would be the more effective if it were made in itself beautiful and distinguished. So instead of leaving it to the journeyman modeller he made a 
special commission of it for a young sculptor and that individual. content to do it for a very reasonable price, produced a really fine thing. It is not a solitary instance, but I maintain that it is not by any means a representative one, either; such occurrences are decidedly not as common as they ought to be.

The American who is building a gorgeous house for himself thinks nothing of paying a large sum for a mantelpiece extracted from one of those old palaces. Why has he not the courage to tell his architect to get hold of some young sculptor and for the two of them to put their heads together and make him a work of art in the shape of a mantelpiece or a door frame? And here, again, I would point out that there are many opportunities for the use of sculpture lying between the great statue and decorative architectural carving. In the Piazza of St. Mark, at Venice, there are three flagstaffs set upon bronze pedestals, and in all Venice there is nothing more artistic than those very pedestals, which a sculptor, Alessandro Leopardi, modeled. What village in the United States is without its flagstaff, and how often is that flagstaff enhanced by even a hint of beauty? Wouldn't it be wise, wouldn't it be the part of common sense, to spend a comparatively small sum of money on a handsome pedestal in lasting bronze? Nay, if you could not afford even that, could you not take pains over something in a cheaper material? An artist can do wonderful things in wood if only he will give his mind to it, and if only we will all get into the habit of valuing beauty for its own sake and not make a fetish of its cost.

In that Renaissance to which I am always coming back artists designed lanterns and door knockers, andirons and salt cellars. These things that they did are preserved today as treasures in the museums of Europe. I do not think that we have learned as much from that lesson as we might learn, and this brings me to a closing word on common sense in craftsmanship. I have studied very carefully the results of the "arts and crafts" movement in this country. It has been productive of much good. But a great number of our "artistic craftsmen" seem to me to be moving about, as the saying goes, in worlds not realized. They have a vague feeling that the thing for them to do is to make a useful 
thing beautiful, so they sail in to spoil a good piece of wood, drawing a pattern on it with a hot poker, or they make you a fearful and wonderful design which they call a wall paper. or they fabricate absolutely unwearable ornaments and offer them to you as jewelry. Their exhibitions are amusing, no doubt. But they spell misdirected energy. These craftsmen begin at the wrong end. They try to walk before they can creep. They do not first make themselves thoroughly acquainted with the characteristics of the material in which they mean to deal, learning wood as a cabinet maker learns it ; knowing metal as a blacksmith knows it. They make their designs from the outside, as dilettante, and not practical workers, as men of common sense. And the important point is that this is not altogether their fault. They are left too much to themselves; they are left to produce their little objects, and then to offer them for sale in an exhibition. They will get their real chance, and be stimulated to prepare themselves for it, when America demands the fruits of craftsmanship as it now demands paintings and statues, when the community that lacks the funds for "monumental" embellishments will cut its suit according to its cloth and take the small thing seriously.

The National Art Federation will render a practical service to the country if it will help to bring about this development of common sense.

The Chairman. I will call attention again to the fact that the delegates are expected to discuss the papers which are delivered, or to give utterance to any thoughts that these papers suggest.

Miss Levy. Will Mr. Cortissoz tell us, perhaps, of some things which have already been done along these lines as an encouragement to others to do more?

Mr. Cortissoz. I have not seen very many. The little wreath I spoke of is one. I have known of an Italian who has brought to this country a few bronze knockers that he has designed, and here and there in different exhibitions I have encountered pieces of craftsmanship that seem to me to give promise in the right direction, but $I$ am not aware of any serious tendency of the people at large and of societies definitely to employ a craftsman, instead of leaving him to 
produce some little item, and then take it out and offer to sell it. What $I$ am insisting on is that the craftsman should be employed just as the painter or sculptor is; that in small ways we should take him very seriously; go to him for knockers or andirons precisely as to an architect for a house. I do not know that that is now done. Possibly some one does know. If he does we would be greatly interested to hear.

Miss Levy. How about the electrolier that was erected by the Municipal Art Society at 23d Street?

Mr. Cor'rissoz. That I think is a step in the right direction.

Miss LEvy. Also the competition for the flagstaff in front of the City Hall?

Mr. Cortissoz. I do not recall that.

Miss Levy. Unfortunately, the city did not provide the funds for doing the work.

Mr. Cortissoz. In the Architectural League, too, a great many of such competitions have been held, you know, from year to year and medals have been given. The Avery medal, I believe, goes to such purposes.

Miss Levy. The designing of those medals and the competitions for the catalogue covers would come in that class, would they not?

Mr. Cortissoz. Yes, but that seems to be very slight.

Miss Levy. But, still, there is a movement that is being carried out in the matter of the memorial tablets in-Mr. Harris, will you please tell us about that?

Mr. HARris. There is now being executed, under the auspices of the Municipal Art Society, two tablets for the Police Headquarters in New York. One is to be placed on either side of the main stairway, leading up to the upper story, and on these is to be inscribed the names of the heroes who died in the performance of their duty as policemen; thus they are to be called "Hero Tablets for the City of New York."

Mr. Cortissoz. All of which seems to me a very splendid recognition of our heroes, but none of these things, or all of them, taken together, seem to me to spell quite enough energy or quite as much organization as is necessary. 
Mr. Harris. I agree perfectly, and I merely supplied the information asked for by Miss Levy, the Municipal Art Society of New York had devoted money to this purpose rather than to a statue or something of that kind.

Mr. Townsend. It seems to me that the question that has been so ably presented by Mr. Cortissoz borders very closely on that old and always debatable question of where you are going to draw the line between the artist and the artisan. There is no question either of morality or moral in the minds of those who had to study or visit the so-called Arts and Crafts exhibitions in New York, the past ten or eleven years. The art tendency of the country has for many years manifested itself generically through what might be called an Arts and Crafts movement. Agricultural Fairs of our youth, with their dozens of doilies and tidies, the best needle work, and so on, were in a certain sense an Arts and Crafts movement. The trouble is that now too many go into the Arts and Crafts who are not artists in the true sense of the word. They may have artistic feeling and artistic temperament, and perhaps a few might develop into artists, but the majority are artisans, and if they would be willing to work as artisans in a commonsense way, and try to obtain employment for the manufacturing of ornamental and useful goods many of them would be earning a livelihood instead of, as at present, passing their lives in despair. That is the crux of the question, I think. An instance of the practicability of these principles is given in the New York School of Applied Design for Women, built up by Mrs. Dunlap Hopkins. There the students do not pretend, nor aspire, to be artists, but bend all their energies toward becoming artisans, and, as a result, when they graduate they almost always find excellent positions open to them in large wall paper, carpet and other manufactories. These young women are trained artisans. Here is the common sense Mr. Cortissoz recommends actively brought into practice, for these young women with artistic tendencies and temperament are taught to do useful, practical and beautiful work. It is along these lines that the arts and crafts movement might prove really serviceable. But take one of the usual arts and crafts exhibitions and what have you? A hodge-podge of ill- 
formed productions, manifesting a striving for something, but no more. The exhibitors call themselves artists and would reject the idea that they should be employed as artisans. The movement itself is laudable, but it must be developed with more common sense. A standard must be established and enforced by the managers of the exhibitions, which will keep the work in the hands not of artists who may wish to experiment, but of artisans who are trained to it as a profession.

Mr. E. C. Messer. It would seem to me that common sense would lead us not to try to draw a line, as the gentleman does who has just spoken, between the work of artists and the artisans, but rather rid ourselves of any idea of caste. There is good art, and bad art, and that should be the only distinction made; and if that idea of caste is removed, then the artist, I really believe, will not sulk in his tent, waiting for some big commission, when he might model the pedestal of a flagstaff.

Mr. E. J. PARker. Mr. Cortissoz's statement prompts me to say that I come from a city which manufactures perhaps more stoves that any city west of the Hudson River. We like to sit around our open grate fires and let the imagination take its flight, and we go over the country for the best andirons we can select, and all that, but I want to center your thoughts on the cooking stove, the range, the family heater. We send our stoves from Alaska to Mexico. Why cannot some of the young artisans design arabesques-to use a large word for a small matter-to embellish the family cooking stove? There is a chance! For every cook, every housekeeper, every boy and girl, and the man who provides for the family have got to look at those stoves. You can center your line of vision from the Atlantic to Louisiana on cooking stoves, ranges and heaters-a good place, using Mr. Cortissoz's words again, for common-sense in artistic designing. (Applause.)

Mr. Hennen Jennings. I am not an artist. My work is in the engineering line, but one thing impresses me that artists have to meet. They have to meet an invention of the age which did not exist in the past-the camera. The camera has brought all the art of the different parts of the world together, 
and caused the artisan to lose his individuality. We have also got a new material which did not exist in the past-steel, and its wonderful power of being molded to gigantic forms and small forms gives more problems. These are two new factors in art, which common sense cannot ignore, and I think these are the problems that the artist has to meet today without going back to the past for inspiration; to meet squarely, in the spirit of the time, and conquer.

The Chairman. There is no organization in our country that has done more for the development of its city than the Metropolitan Improvement League of Boston, and no man has done so much to inspire that work and make it possible by his constant devotion and enthusiasm than has Mr. Sylvester Baxter, its Secretary, whom I now introduce. (Applause.) 


\section{THE METROPOLITAN IMPROVEMENT LEAGUE OF BOSTON.}

\section{ADDRESS OF \\ Mr. Sylvester Baxter.}

Mr. Chairman, Ladies and Gentlemen: What I have to tell about is the brief history of a simple organization that aims to work along practical lines in promoting civic improvements, The Metropolitan Improvement League of Boston. It is still in its youth, but it already has a record for admirable work. In the first place, I should say that prior to the organization of the Metropolitan Improvement League many excellent things had already been accomplished, as well as many other most desirable things left undone. It has all been a sort of natural development out of established conditions. For instance, from early days Boston has been the chief center for the Horticultural and Floricultural interests of the United States. This naturally led to the formation of the Massachusetts Horticultural Society. An early activity of this society was the inception of the rural cemetery movement. Mount Auburn Cemetery in Cambridge was the prototype of the rural cemetery of the United States-something, in view of subsequent development, perhaps not altogether to be proud of, but in those days, early in the nineteenth century, the rural cemeteries were the principal show places of the suburbs; strangers visiting in Boston were almost invariably taken there to drive and to see the handsome monuments in the landscape environment whose charm they ruined completely, just as today they are taken to drive through the parks. Mount Auburn was established by the Horticultural Society as a public-spirited undertaking, but the sale of lots resulted in an immensely profitable real estate operation. This made the Massachusetts Horticultural Society the richest organization of the sort in the world. In view of the good which it has done with the funds thus acquired much may, therefore, be forgiven it. In one of its annual reports, about thirty years ago, the Horticultural Society congratulated its members upon "the prosperous year at Mt. Auburn." Apart from the funereal suggestions, the 
public had also reason to join in the congratulations, for this society has led in many admirable undertakings for the improvement of outdoor art, one of the principal being the agitation for the establishment of Boston's unrivaled park system. Other important factors in these directions have been the Appalachian Mountain Club and the Trustees of Public Reservations.

A few years ago some of us felt the need of some organized activity which would keep a constant lookout for matters of this sort. Not only to prevent bad things from being done and to cause good things to be done, but to prevent many things goings by default when once undertaken, because what was everybody's business was nobody's business, and things were not looked after until too late. Too frequently had it happened that we did not think of locking the barn door until the horse had been stolen.

The organization as finally determined took the simple form embodied in the structure of the Metropolitan Improvement League. Our first thought was to have a federation of all the societies represented in public work and public improvement, such as the Boston Society of Architects. But in this particular sense it was concluded that it would not work well; it would not be quick enough in its operations; there would be too much reporting back to the various organizations for getting authority to act, and all that sort of thing. So, the organization that finally resulted, after much conference, was very simple. Here $I$ have given the purposes and the organization of the League as follows:

The League was organized-

To encourage and safeguard the physical growth of Boston as a metropolitan community along well-considered and wellplanned lines, that should assure the largest possible measure of convenient and artistic development.

To see that all matters that materially related to the proper planning, constructing and beautifying of things in which the public had legitimate concern were rightly considered and rightly attended to.

To see that new projects that involved material changes, such as are constantly being brought forward in this growing 
metropolitan community, should, if decided upon, be carried out with the greatest possible effectiveness.

To see that the public was kept duly informed and its interest awakened in regard to matters that thus affected it.

To focus the efforts of the various other organizations throughout the metropolitan district, which, in one way or another, may be concerned, in kindred lines or public-spirited work, and serve as a clearing-house for the promotion of ends that they may commonly have at heart.

Then in the second clause of the constitution the name and object: "The object of this League shall be to further the physical betterment of Boston and its surroundings by endeavoring to bring about effective co-operation and stimulate increased activity among those who are working to make the Boston district more beautiful, convenient and economical as a place of residence and work, and by advocating or opposing propositions for public works as they may seem to further or impede those ends."

I would say that the League does not concern itself alone with what is known as the city of Boston. The city of Boston has about 600,000 inhabitants; the real city-the metropolitan community, which is partially organized, known as Greater Boston-has a population of a million and a quarter and more, and that is the field of our League. It is composed of something like forty different municipalities-clusters of cities and towns surrounding the central city. We have in our organization the usual President and Executive Committee, and then a Membership Committee, a Legislative Committee, a Committee on Public Monuments and Decorations, and a Committee on Civic Appreciation. The present President is well known to many of you here, Mr. C. Howard Walker, the architect, who designed the Omaha Exposition and had much to do with other expositions, including that at St. Louis. The Secretary is before you. The others of the Executive Committee are Dr. Henry Lefavour, President of Simmons College; George Howland Cox, who is the Chairman of the Cambridge Park Commission; F. L. Olmsted, Jr., Professor of Landscape Architecture at Harvard; whom you all know by his magnificent work as one of the Park Commission of the District of Colum- 
bia in devising the memorable plan for the improvement of the capital; James B. Noyes, a prominent business man; and William W. Churchill, one of the first to suggest our league, and a prominent painter.

The membership fee is $\$ 5$ a year, and we have many leading citizens as members; while the fund thus obtained is not large, it enables us to do, with due economy, considerable practical work. We employ legislative counsel, and in this way have been able to secure some important things. The first thing we set ourselves about doing will here be considered last, because it was the most important. Although at the very first we set out to do this thing, it has been one of the last things accomplished. The Chairman of our Legislative Committee has been Mr. J. Randolph Coolidge, Jr., another very prominent architect, and who has been President of the Boston Society of Architects, and who has such an admirable way of presenting things that he has been very successful in enlisting the interest of Legislative Committees.

We have taken great interest in tree-planting for our streets. We secured the transfer of the extension of Commonwealth Avenue-one of the celebrated thoroughfares of the world. An extension of Commonwealth Avenue runs far out into the suburbs, and we secured the transfer of that part of the Avenue to park development, under the law which was secured by the preliminary Metropolitan Park Commission. That was for the purpose of causing trees to be planted there, a duty that had been neglected by the city greatly to the detriment of public interests. Then a radical change had been made in the tree-planting scheme of the Avenue in its original part-a substitution of a two-row plan for the original four-rows, involving the cutting down of many fine old trees-something that was very much like vandalism, although advocated very sincerely by some of our best citizens. Our exertions secured a return to the original four-row plan, which was in consonance with the design of the Avenue. The latest tree-planting activity is a very interesting movement on the part of residents of Beacon Street, which is almost entirely treeless. The citizens have come together and asked the Metropolitan Improvement League to submit a plan for the 
comprehensive planting of that thoroughfare. We are about to do that.

The protection and improvement of parks and open spaces has been an important phase in our activities. The Charles River bank-the pioneer playground in the modern playground movement for the United States-had been greatly neglected for various reasons, partly through lack of appropriations, partly because of political influences, and we have moved to secure a better appearance of things there. Soon after the city of Chelsea was nearly destroyed by fire, a little over a year ago; as a sort of consolation Congress made an appropriation for a new Post Office building. We endeavored to see that the post office was properly located. The Board of Control proposed to locate it in the center of Winnisimmet Square, greatly to the injury of one of the best designed public open spaces in the Metropolitan District. After our consultation and remonstrances with the Board of Control there was a public meeting and the citizens almost unanimously voted against having the Post Office in the square. A better location was selected for it, making it a feature of a new civic center that included the City Hall, Public Library, and the Armory.

We also moved towards preventing the occupation of an open space for building purposes-an open space in front of the Sears Chapel, on the beautiful parkway between Boston and Brookline. Sears Chapel is one of the most picturesque objects in the suburbs, and contributes to the beautiful rural English effect of the Riverway-a charming portion of our Park system.

Another very important activity was in inducing a better policy on the part of the Boston Elevated Railway in the way of civic design. Here in Washington you have had an instance that, of course, is very important. The action of the late president of the Pennsylvania Railroad Company in removing the station from Pennsylvania Avenue and establishing the present Union Station, shows how great public corporations may be induced to do things in the right way when they are rightly brought to their atention. The Boston Elevated had secured the right to build an extension of its line 
from Dudley Street, its present terminus, out to Forest Hills, running along one of the great thoroughfares. Near its new terminus it was to cross the great parkway which is already crossed by the New York, New Haven and Hartford Railroad -over a handsome stone viaduct, beautifully designed in consultation with the Park Department. In the legislation authorizing the extension no precaution whatever had been taken to protect the public interests there. The Elevated had the right to run its steel strucure across the parkway, making an ugly blemish at this point. The League took the matter up and went to the Mayor. The Mayor reported that he had no authority to do anything, but was very sympathetic, and he said he would exert his influence so far as possible. Then we went to the management of the Boston Elevated. The President was a member of our League. Our Committee consulted with him and he referred us to their chief engineer. The chief engineer looked over the matter and the result was that the Elevated authorities said that they would do whatever possible there as desired by the public. In consequence a Committee of Consulting Architects, selected by the Boston Society of Architects at the request of the Boston Elevated Railroad Company, was appointed by the company to look after all matters of design where their construction in places was contemplated. A vast improvement has resulted. This crossing of the parkway is to be a very handsome structure of reinforced concrete. Messrs. Wheelwright and Haven designed the new station at Forest Hill and made a pleasing effect by enclosing the steel support of the elevated structure in concrete piers.

A still more important outcome has been the design of the viaduct which is to close the prospect looking down the new Charles River Basin- "Charlesmere," as it is now appropriately called. This great basin of fresh water has been changed from a tidal basin, and a dam and causeway are under construction at the lower end of this basin. It was proposed to run the elevated structure in the ordinary fashion, adjoining this causeway. But Mr. Robert S. Peabody was appointed the architect, and he has designed a very handsome structurea viaduct of reinforced concrete arches. 
In various ways in the design of our new subway-our new Washington Street tunnel-in the decorations-the influence of the League has been felt.

In the matter of ancient landmarks-the old houses, the public buildings of Boston, are one of the greatest assets, both historically and even commercially, as an attraction of the city. We moved to secure the preservation of the ancient Royall House, the old homestead of Governor Winthrop in Medford; and prevented the demolition of the old West Church, now the Branch Public Library of the West End, one of our historic structures.

In street improvement we were active in securing the laying out of the New Avenue, constructed on the axis of the central group of the Harvard Medical School, a very beautiful group of marble buildings, at the Avenue Louis Pasteur, as it is called.

Boston harbor is filled with many islands, but from the early Colonial days they have been destitute-most of them-of the original tree covering, and are consequently bald and repellent in appearance. A very slight outlay for the planting of trees will cause almost an immediate change in their appearance. The moment that leafage appears there the new surface texture will greatly improve the looks of these islands. Therefore, we have revived a movement which was instituted something like 30 years ago to do this thing, and which was unfortunately blocked by the action of the Mayor at that time. We are now organizing to have that done, getting various interests together-the various organizations interested in such things, like the Appalachian Mountain Club, the Massachusetts Forestry Association, etc.,- to secure that action.

Another thing, we lately caused the Mayor to request of the Art Commission a report upon the advisability of making changes in the arrangement and the location of monuments, statues, fountains, etc., upon the Common, Public Garden, and other public open spaces. Many of these are very badly placed, and some of them are very bad, indeed, in themselves. Most of the monuments of a more early period, and even some of a very recent date, are bad, andspeaking in all .confidence, of course!-our purpose is 
to get some of these out of the way, and have them discreetly screened by trees and shrubbery, so that they will not be so conspicuous. Possibly some of them may be removed altogether, as they ought to be. The Mayor has requested the Art Commission to make a report. The Art Commission in turn has requested the Metropolitan Improvement League to consider the subject, and a Committee has been appointed-a Committee of Architects and Landscape Architects.

These are some of the things we have done. We have endeavored to secure proper utilization of the Parkman funda bequest recently made to the city of Boston for the maintenance and the improvement of public parks. It amounts to about $\$ 5,500,000$, the income to be devoted to these purposes, making the greatest fund of the sort ever left to any city in this country, and, I believe, the second largest fund of the kind left to any city in the world. The bequest of the Duke of Brunswick, to the city of Geneva, in Switzerland, I believe is the largest. We are hoping to secure a proper utilization of that income.

There remains to be considered the first activity of the League: the remarkable interest aroused throughout the country by the plan for the improvement of Washington, prepared by the Art Commission of the District of Columbia, led our League to decide that our first activity should be to secure the organization of a plan for the Metropolitan District. It makes a long story-altogether too long to go into here. To sum it up: after having secured in the message of the Governor a strong recommendation of this project and favorable action by the Legislative Committee on Metropolitan Affairs it was reported upon adversely by the Committee on Ways and Means, for fear it might commit the Metropolitan District to some expenditures large and indefinite, involved in carrying out whatever plans might be agreed upon. Four years later, when it became more opportune, it was brought up again, and the Commission on Metropolitan Improvements was constituted. The term of that Commission, of which I have the honor of being Secretary, expires this week, and it has some very important plans for Metropolitan Improvement 
dealing with questions of transportation, of local transit, of railroad terminals, and of Metropolitan highways. They all dovetail together in a large ensemble, significant of an intelligent and scientific development. While we were requested, among other things, to consider matters of embellishment, we felt that embellishment should be an outgrowth of the practical, and expression of the useful in terms of art, and that side of it would take care of itself as the occasion arose. Our plan in Boston, of course, must be a very different plan from that of Washington. In Washington the dominant note is elegance-that is the fundamental idea. In Boston it is the picturesque, the spontaneous expression of the logical development of an old community from Colonial days upwards, and the sort of plan we hope to achieve should be characterized by that quality, as a natural growth of any kind tells of the soil it springs from in the individuality thus determined. Then another thing that I should mention is the Local Improvement Organizations, similar to the Village Improvement Societies of which you will doubtless hear in the course of this meeting. The Village Improvement Societies, some of them organized fifty years ago in New England, and the Ward Improvement Associations and the Local District Improvement Associations have done a great deal of good for their own communities. But in the atmosphere of a great city the latter have also in many respects exerted a baneful political influence. Hence the log-rolling tendencies and the extravagant expenditures which they have encouraged, and they have been sort of hot-beds for ward politics, some of them. The idea has occurred to some of our leading citizens that there was a great field for usefulness in these organizations; that if they could be got to work together they could do a great deal of good, not only for their own localities, but for the city at large. And so they have organized the United Improvement Associations-a strong organization which promises to do much good and to bring about a new way of doing things, for the general as well as the local welfare.

Then, finally, we have in Boston, the very interesting movement called the "1915 Movement," which sets an ideal in various respects for things to be accomplished six years hence 
-that is, by 1915. Fundamentally, it is a very simple idea; that is, to have the various public-spirited interests, each of which desires something, in the way of better housing and of better streets and of better financial conditions, etc.-have them each fcrmulate what it wishes to have accomplished, and then all work together unitedly for the accomplishment of these things, one helping the other. Many of us hope this will result in something very fine being accomplished-and then by 1915 we can invite the rest of the country to come and see us. (Applause.)

The Chairman. The Secretary has an announcement that he wishes to make.

The Secretary. We wish to call attention to an occurrence in Washington last week which deserves our hearty commendation. In a speech before the Washington Chamber of Commerce and the Washington Board of Trade, President Taft devoted half of his address to the systematic development of the Capital City, and his intelligent interest and appreciation of the original plans designed by L'Enfant, and the principal artistic legacy left us by George Washington, his hearty approval of the future development of the city on the Park Commission plan, his feeling that the city will develop on these lines, his expressed intention of throwing the weight of his influence towards this end, should delight all interested in art.

Therefore, I move that the Delegates to this Convention, representing over eighty organizations in all parts of the United States, heartily approve and thank the President of the United States for his expressed intention of aiding this most important movement in the development of the Capital City. I would also feel, myself, like suggesting three cheers for President Taft. (Prolonged applause:)

The following resolution was then presented, duly seconded, and unanimously adopted:

Whereas, William Howard Taft, the President of the United States, in an address before the business men of Washington has shown his intelligent interest and appreciation of the plan 
of the city drawn by L'Enfant, the principal artistic legacy left us by George Washington, has given his hearty approval of the future development of the city on the Park Commission's plan, has expressed his opinion that the city will be developed on these harmonious lines, and has intimated his intention of aiding in this rational development of the Capital City, therefore, be it

Resolved, That the delegates in this Convention representing more than eighty art societies from the North, South, East and West, heartily appreciate and thank the President for his sympathy and assistance in this important movement for securing beauty, grandeur, and harmony in the future development of the Capital City.

The Secretary was instructed to send a copy of this resolution to President Taft.

The Chairman. Mr. Baxter referred to the late Mr. Cassatt, the President of the Pennsylvania Railroad. I fear there are very few men at the head of the great corporations of our country who are as public spirited as was he, and I think this whole country owes him a debt of gratitude for what he did for Washington. (Applause.)

Mr. Albert Kelsey. I wish to extend a little, if I may, the remarks of Mr. Sylvester Baxter, than whom no one in Boston has done more to bring about a new type of citymaking, by pointing out that this subject of city-making is one of far-reaching importance to this organization.

I take it that of those present here the great majority are urban or at least suburban dwellers, and that art must necessarily prosper best where there are most people.

In the address we listened to with so much pleasure by Senator Root only yesterday, he made it very clear that he had some very broad and comprehensive views on the subject of art organization, and what an organization might do if it applied itself in a vigorous manner to enlist the support of our people, not only in municipal but in state and national affairs. We are gradually evolving a type of city in spite of all kinds of mushroom enterprises and much blundering, which is going 
to be a great advance, I believe, on any city-making that has yet been brought forth in Europe. On the other hand, we are way, way behind in understanding the economic development of closely built up districts of our cities, and it seems to me that this organization should take into consideration what has been slowly evolved in Europe. Modern city-making started in France; it is being perfected in Germany. Cities of the first, second and third class in Germany have a regular department of Municipal Extension; stampedes in real estate values by private individuals are averted; franchises of all kinds of public utilities controlled, and the city expands rationally and in a very decent way. The consequence is that the Presidents of all kinds of Art Societies, like those represented here, interested in all kinds of phases of art, can apply self-perpetuating development to the members of these Departments of Municipal Extension-and thus can be assured of a continuous development, and that any effort set forth by any organization for the benefit of a neighborhood, such, for instance, as the Neighborhood Improvement Work which is being done so well in Chicago, will be carried on systematically, and that a great overlapping and waste of money and energy avoided, and I trust that before we go much farther with our deliberations here, that we will try to carry our work on in such a way that there will not be an overlapping of effort and obscurity as to what the organization is for.

It has been my privilege to come in contact with Senator Root in business very frequently, and he is most anxious to see organizations grow up in the various states, and a National organization which will be of real power, and, speaking for some of the architects present, I feel sure that we are destined to accomplish something, if we can only constantly keep in mind this broad work which is before us. The work of the Metropolitan Commission in Boston, which has been imitated in many cities, represents a totally different phase of city development from anything that Haussmann ever dreamed of. The European idea, or the Continental idea, of city-making is perfecting physical development within narrow boundaries; it is a purely municipal project. Boston has swept that idea away completely. The twentieth century idea is for 
a federation of cities and suburban communities as Mr. Baxter has told you, within the work of the Metropolitan Commission with the various Commissions around Boston, where forty, more or less jealous communities, are working in perfect harmony. It is a marvelous thing, and a matter which is full of great encouragement for us all, to think that it was possible to conciliate the rivalries and the jealousies of thirty or forty different communities, and to get them to work in perfect harmony for a result which has already born fruit that was beyond the expectations of Mr. Baxter and Mr. Eliot, who brought this feature into being.

Now, if under our system of ever-changing administrations, and with such an intricate body politic to handle as thirty different town governments-it has been possible in so few years to gain possession of the water fronts along the seas and along the bays and rivers in and about Boston, to control the entire water shed of the eastern slope of Massachusetts, to have parks and parkways link up all these different towns, it is possible for us to do almost anything if we get right down to modern trust methods and organize a strong national body with a very distinct object in mind.

I do not think that I want to take up any more of your time, but it is this idea of centralization that I wanted to bring to your attention. (Applause.)

The Committee on Constitution then presented a rough draft of its report which was discussed, section by section, at considerable length, several paragraphs being referred back to the Committee for reconsideration.

After which the Convention adjourned to reassemble at 2.30 o'clock. 
FOURTH SESSION.

Wednesday Afternoon, May 13, 1909.

In the Ball Room, the New Willard Hotel. Mr. H. Winthrop Peirce, 3rd Vice-President of the National Academy of Art, in the Chair.

The Charrman. It gives me great pleasure to introduce to you, ladies and gentlemen, Dr. John Quincy Adams, the Assistant Secretary of the Art Commission of the city of $\mathrm{New}$ York, who will speak on the work of that Commission.

THE WORK OF THE ART COMMISSION OF THE CITY OF NEW YORK.

\section{ADDRESS OF}

Dr. John Quincy Adams.

Mr. Chairman, Ladies and Gentlemen: Shakespeare has said, "Some are born great, some achieve greatness, and some have greatness thrust upon them." However true this may be in regard to individuals, institutions seem often to be made by all three factors working together and this was the case with the Art Commission of the City of New York. It was brought into existence, as you know, on January 1, 1898, by provisions in the Charter of Greater New York. Those who drafted the Charter provisions were able and wise men, consisting of Messrs. John M. Carrere, Chairman, Russel Sturgis, Walter Cook, Frederic Crowninshield and Henry Rutgers Marshall. These gentlemen in consultation with able lawyers, after drafting this section of the Charter, presented it to Mr. Elihu Root who was a member of the Charter Commission. Senator Root gave them a number of valuable suggestions which were incorporated and this draft was finally adopted verbatim by the Charter Commission. 
The membership of our Commission consists of three classes: First, the ex officio members, consisting of the Mayor, the President of the Metropolitan Museum of Art, the President of the New York Public Library, and the President of the Brooklyn Institute of Arts and Sciences. Second, the appointees-each of these is appointed by the Mayor from a list of three furnished him by the Fine Arts Federation of New York. Then the third class may be called temporary members. The Charter provides that when any plans are being considered which come under the jurisdiction of some department of the city, the head of that department is a member of the Commission during the consideration of these plans. $\mathrm{He}$ has all the rights of the other members. Too much praise could not be given this last provision of the Charter, because when it happens as, of course, it frequently does, that plans must be disapproved, the head of the department who has submitted these plans may be present and hear the reasons given for their disapproval. Now, as you will at once see, this maintains cordial relations between the Commission and the various city departments and has undoubtedly done much to foster mutual confidence and respect. During the consideration of designs for important structures, not only the head of the department, but his engineer and technical assistant often appear before the Commission. The Art Commission refuses to consider designs until they have the certified approval of the head of the department under whose jurisdiction the structure is to be erected.

So much for the birth of the Commission and now in regard to its achievements. I may say that it has exercised its power with great wisdom and discretion. The Commission does not expect nor attempt to get masterpieces in every case. Its decisions are not based solely on artistic and ideal qualities, for with the City, as with the private individual, many practical questions must be taken into account. What the Commission persistently does, is to prevent the erection of the ugly and unsuitable, and in each case to secure the best possible structure under the circumstances. Consequently, its achievements are not to be found so much by comparing the structures it approves with an ideal standard, as by an ex- 
amination of the records on file in its office. Only by comparing a "disapproved" design with its improved and "approved" successor can one form a just appreciation of how much the Commission has done for public art and architecture.

From the beginning the Commission has shown great vitality. It has accepted its full responsibilities and conscientiously performed its functions. At the same time it has always had a clear conception of its jurisdiction and has rigidly kept within its own domain. One of the best testimonials to the discretion and wisdom shown in the exercise of its powers, lies in the fact that by various enactments its jurisdiction has been gradually extended. During the first four years of its existence it had jurisdiction only over works of art. It passed upon the designs of public structures solely when requested to do so by the Mayor or the Board of Aldermen. At the present time, the law requires it not only to pass upon all works of art, but upon all public structures and all private structures built wholly or in part upon public land; also upon the lines, grades and plotting of public ways and grounds. The only exception to such juriscliction is that when a structure is to be erected costing $\$ 250,000$ or less, the Commission shall not act if requested not to do so by the Mayor or the Board of Aldermen. Such a request has never been made.

These extensions of its authority have not been in any sense academic innovations. They have grown out of practical experience. As the Commission showed its willingness and ability to cope with the problems of city architecture; as the great benefits of its criticism and decisions became manifest, it became gradually the custom for the Mayor to refer to it, at first, all important structures, and, later, nearly all structures. Hence the various enactments have merely put into legal form what had already become a common practice; thus doing away with much confusion and all uncertainty. Now every department knows that the designs and location of its structures must be approved by the Commission.

The story of the growth and importance of its work is further told by the number of submissions. During the first four years of its life, the Commission passed upon an average of six submissions yearly. During the year 1908, it passed upon 
200 submissions, having an approximate value of $\$ 30,000,000$.

Now in regard to the power of the Commission. Its decisions have always been final. I want to say a word in regard to the manner in which the Commissioners perform their functions, as I have often heard it said that their action is merely perfunctory. This is a totally erroneous notion. Not only are designs given careful consideration before action is taken but when necessary the sites of the proposed structure or monuments are visited by the Committee and carefully studied with the designs before them. It frequently happens that the Commission goes out, spending many hours visiting sites and carefully studying the whole question as to the fitness of the proposed structure for the intended location.

If you will look at our report for 1907 you will see there in illustrated form what the Commission has actually accomplished in a few instances. Take the matter of drinking fountains, those horrible things that have been scattered through the United States, made of cast iron without form or void, by different iron works. To have sounded the death knell of cast iron drinking fountains in New York City is no small accomplishment. Only once, I think, during the past year have we had an iron drinking fountain submitted, and that after an improved design. Now in place of these, there are being put up all over the city beautiful bronze fountains, or if just a trough is wanted, a very beautiful and simple granite trough. I think I may say that the Commission has won the sympathy and co-operation of the Society for the Prevention of Cruelty to Animals, which is the chief organization in putting up drinking fountains for horses.

Now, in closing, let me mention two or three directions in which the influence of the Art Commission is most decidedly felt, in addition to its securing better designs for structures as well as better designs and more suitable locations for monuments. First I may mention that the Art Commission of New York stands for training in architecture, in sculpture and in painting. It is rare now for an architect to submit designs for public buildings. The departments in general select trained men because they must get the approval of the Art Commission. Otherwise, the money for the building cannot 
be legally paid out of the City Treasury. I think it may be said without contradiction that there has been a steady improvement in the character and ability of men employed in designing buildings for New York City. Secondly, the Art Commission stands for good city government. There has never been a suspicion of such a thing as graft or pull in our department. Every Commissioner must be like Caesar's wife, above suspicion. The Commission gives the same consideration to a Saint Gaudens, an Adams, French or Bitter design that they do to that of a young sculptor. In other words, all designs are considered in an entirely impersonal manner and are dealt with strictly according to their merits. (Applause.)

Mr. Eli Harvey. Mr. Chairman, I should like to ask Dr. Adams a question.

The Chairman. He would be very glad to answer, I am sure.

Mr. Harvey. I heard it said, yesterday, by an ex-member of the Commission, that it is possible for work in sculpture, or architecture, to be perpetrated upon the city, in their ignorance of it, and after put up once it is a very difficult matter to have it taken down. Is that a fact?

Dr. Adams. Yes, sir, it is a fact. There is one public building today in New York City where the sculpture was put up some years ago and that sculpture, I suppose, will be paid for out of the City Treasury. It never has come before the Art Commission. In the early years, perhaps the first four or five years, the Commission was feeling its way, and did not want to be too assertive. It was getting the confidence of the public. Many architects did not know that their designs had to be submitted to the Commission, and the Commission does not like to disapprove of a piece of sculpture after it is on the building and can not easily be removed. It would make a very embarrassing situation; but it is a fact that it has been only in the case of one building.

Mr. HARvey. I had reference to a large monument on, 72nd Street, I believe it is, and Boulevard or Broadway.

Dr. Adams. No, sir, that was approved by the Commission. You refer, probably, to the monument to Verdi? 
Mr. Harvey. Yes, sir.

Dr. Adams. Yes, that was approved by the Commission. Of course, what we try to do, if I may just say one word more, is to get the sculptor to submit his sketches first. They do not always know the method of procedure, and just at the present time the Commission is preparing a circular to be sent to all the sculptors and architects telling them exactly the best way to get things before the Commission. A committee, you know, anxious to put up a monument will hurry the thing along, and once in awhile the statue is cast in bronze before it is submitted to the Commission. You can see that this makes an embarrassing situation. If the Commission does not like a thing, it must disapprove, and I may say the Commission shows a very rigid back bone when it does dislike a thing. I have seen things submitted four or five times, and each time turned down, and it is surprising how rigid the Commission is when it really feels that the work is unworthy of a place.

The next speaker was Mr. George Oakley Totten, Jr., who had kindly consented to give his illustrated lecture, delivered originally before the American Institute of Architects, on the International Congress of Architects, held in the summer of 1908 at Vienna, at which he represented the United States. Mr. Totten's address being printed in full in the proceedings of the American Institute of Architects' last Convention is here omitted.

The Committee on Constitution then presented its revised report which was again generally discussed and carefully considered. Each article being voted upon separately, the Constitution as a whole was finally adopted. It is as follows: 
Article I.

Name.

The Corporate name of this organization shall be "The American Federation of Arts."

Article II.

Objects.

The objects of this Federation are to unite in fellowship all institutions and organizations, interested in architecture, sculpture, painting, landscape, craftsmanship, collections of art, and village and city development; to harmonize and nationalize the art interests of the country; to stimulate the love of beauty and to cultivate public taste.

\section{Article III.}

\section{Membership.}

Section 1. This Federation is an association of institutions and organizations, each of which shall constitute a chapter.

SEC. 2. All institutions and organizations interested in the objects of this Federation shall be entitled to representation in its conventions as follows: One delegate for the body as a whole, one delegate for any number of members, whether of faculties or organizations, not exceeding twenty, and one delegate for every twenty members exceeding twenty.

SEC. 3. No chapter shall be allowed more than ten delegates.

SEC. 4. No student of any institution or organization shall be counted a member of the chapter.

SEC. 5. Any person interested in the objects of this Federation may, on approval of the Committee of Admissions and the Board of Directors, become an Associate upon application and the payment of two dollars a year; but only delegates shall have the right to vote at conventions.

SEC. 6. The President and Board of Directors shall have the power to confer the title of Honorary Member upon any 
person who, in their judgment, has rendered distinguished service in the promotion of any object for which this Federation exists.

SEc. 7. Any person may, on approval of the Committee on Admissions and the Board of Directors, become a Life Member on the payment of one hundred dollars.

SEc. 8. Any person may, on approval of the Committee on Admissions and the Board of Directors, become a Patron on payment of one thousand dollars or more.

SEC. 9. No institution or organization shall be eligible to membership any part of whose monies is applied to private gain.

Article IV.

\section{Office and Officers.}

Section 1. The head office of this Federation shall be at Washington, D. C.

SEC. 2. The officers of this Federation shall be a President, three Vice-Presidents, a Secretary, an Assistant Secretary, and a Treasurer, who shall serve for two years, and shall be elected by ballot at the convention.

SEC. 3. The Assistant Secretary shall receive an annual compensation for services.

SEC. 4. There shall be a Board of Directors consisting of the President and Secretary ex officio and nineteen members of the different chapters belonging to this Federation, to be chosen by ballot at the conventions. Three directors shall be retired each year in order of seniority and three new ones elected.

SEc. 5. The Board of Directors may, by formal vote, delegate its powers, wholly or in part, to an Executive Committee consisting of the President and Secretary ex officio and five others chosen by it from its membership. 
Article V.

Government.

The government of this Federation shall be vested in its Officers and Board of Directors and by delegates from the chapters in convention assembled.

Article VI.

Committees.

Section 1. With the approval of the Board of Directors, the President shall appoint, to serve for terms of not less than two years, standing committees of five on Admissions, Finance, and such other matters as Architecture, Sculpture, Painting, Landscape, Craftsmanship, Art Museums and Galleries, Education, Exhibitions, Publication, Municipal Art Commissions, Village Planning and Improvement, Free Art, Government Art, Legislation, etc.

SEC. 2. The Committee on Admissions shall consider the eligibility of any institution and organization wishing to join this Federation, and shall report to the Board of Directors their recommendations. The Board shall have the power to accept or reject the applications.

\section{ARTICLE VII.}

Dues and Penalties.

Each chapter shall contribute to this Federation ten dollars per delegate annually. In default of payment the chapter shall not be entitled to be represented in convention, and after six months may forfeit its membership at the discretion of the Board of Directors.

Article VIII.

Introduction of Subjects.

Upon request of members of at least five chapters, made in writing to the Board of Directors, the Board shall submit 
to the annual convention any subject kindred to the objects. of this Federation.

Article IX.

$B y$-Laws.

The Board of Directors shall have the power to adopt all necessary By-laws.

Article X.

Amendments.

This constitution may be amended only by a two-thirds vote of the delegates present at the meeting, after notice of amendment to each chapter at least two months before the convention is held.

The report of the Nominating Committee was presented by Dr. Charles W. Needham, Chairman.

Dr. Needham. Mr. Chairman, the Committee on Nominations makes a report in two parts. First, with reference to the officers, and second with reference to the nineteen directors, who are to be selected. I will present the first part of the report. We nominate for President, Mr. Charles L. Hutchinson, of Chicago; for Vice-Presidents, Mr. Herbert Adams, Sculptor, of New York; Mr. John W. Alexander, of Pennsylvania, Painter; Mr. Ralph Adams Cram, Architect, of Boston; for Secretary, Mr. Frank D. Millet. The office of Assistant Secretary is left for this meeting to determine. For Treasurer, Mr. J. P. Morgan, Jr., of New York.

These officers being elected, their nominations having been duly seconded, Mr. Albert Kelsey nominated Miss Leila Mechlin as Assistant Secretary, and she was unanimously elected by a standing vote.

Dr. NeEDHAM, then proceeding to the second portion of the report, explained that the Committee feeling it impossible in the brief time at its command, and under existing circumstances, to make a fitting choice of persons who would represent all sections and serve most acceptably, recommended 
that the President, Vice-Presidents, Secretary and Treasurer be constituted a committee on organization with power to appoint nineteen directors to serve for one year, which, being put in the form of a motion, duly seconded, was so ordered.

The business before the Convention being concluded, the chairman introduced Mr. William Woodward, Senior Professor of Drawing and Painting, Tulane University of Louisiana, who spoke on the "Progress of Art in the Gulf States." 
PROGRESS OF ART IN THE GULF STATES.

\section{ADDRESS BY}

Mr. William Woodward.

Mr. President and Members of the Convention: We of the far South desire to take part in the councils of this national movement to forward the interests of art, and I have gladly accepted the cordial invitation to address you, overcoming the barrier of distance which has so long delayed the intercourse which would be very helpful to us at this time when we have, as we think, achieved a position in the art world by the merits of our work in some directions.

What I have to say will be from the point of view of an adopted son of Louisiana for a quarter of a century, one who has been continuously identified with the slow awakening which is now reaching the point when a decisive advance may be expected in common with other sections represented here in convention at our national Capital.

I come to bring what message I can to you, but more than that, to link the Gulf States with the other States represented in plans for active co-operation in practical ways for mutual help and to nationalize our art. At this point $I$ beg that you will allow me to refer to the great success of the International Congress of Art Teachers held last August in London, where about 200 American delegates joined with about 1,600 others from about 40 countries to consider modern problems in Art Education. The utmost cordiality was shown the American committee in charge and every facility was afforded that was humanly possible, the incomplete condition of the new buildings, of the Victoria and Albert Museum being the only unfortunate phase, as it crowded the exhibit too much. But even here it proved a blessing in disguise, as the exhibits were so extensive as to have become wearisome had they been spread out as originally planned.

The work of the public schools of this country was shown only in a composite exhibit from about 60 cities, each grade from the first through the high school on a screen by itself. This arrangement won the most favorable comment, and it may 
be claimed that in this exhibit we excelled. Another triumph was scored by the exhibit sent from the Boston Museum school which had been placed by the committee in a central, toplighted gallery, which was equally shared by the exhibit of the Ecole des Beaux Arts of Paris. The oil paintings from the nude figure showed a higher grade of excellence than that of the Ecole, judged by latest standards. I do not claim that the Ecole is outclassed by the Museum school, but I do claim that the latter made a better exhibit in London.

Many of our best schools of art sent splendid exhibits, but I cannot mention more by name, only adding the comment that all exhibits there emphasized the equal importance of what was formerly termed industrial art.

When the Princess Louise, Duchess of Argyle, formally opened the exhibition at the South Kensington Museum, all delegates there at the time were presented to Her Royal Highness, and the Americans before any other nation, even, although, we were not representing our government which took no part in the Congress. Our reception by the English could not have been more appreciative nor cordial and I take this opportunity to acknowledge it. The entertainments included a dinner to hundreds of delegates by Lords Carlisle and Stanley, the president and treasurer, given at the banquet hall of the Franco-British Exposition, then in progress; a reception by her Grace the Duchess of Sutherland, to all delegates and their families in Stafford House, to which she returned from Scotland with forty servants expressly for that event; a reception by the Duke and Duchess of Wellington and their daughter in Apsley House, Hyde Park Corner, and unusual privileges extended by the King at Windsor Castle, besides many other charming occasions, making this Art Congress one to be long remembered.

An important contribution to this Congress was the book, "Art Education in the Public Schools of the United States," written and published under the auspices of the American Committee, to furnish a correct idea of the history, philosophy and practice of art education in the United States.

All this is pertinent to my theme, as Louisiana furnished a 
member of the official committee of three and the author of the chapter in the book, "Art Education in the Colleges."

There is increasing interest in Art Education throughout the Gulf States and much, for instance, may be expected from the Rice Foundation at Houston, Texas, which has several millions endowment, but Louisiana is so far in the lead as to warrant more being said about her position. A department of drawing was first added to the Southern Educational Association when it met in New Orleans.

The law now requires the public schools of Louisiana to furnish instruction in drawing and manual training, as well as music and usual subjects. The city of New Orleans employs seven supervisors of drawing and manual training.

A devoted band of professional and amateur artists has advanced art in New Orleans for over 25 years with varying success and the Art Association of New Orleans, which now attends to the exhibiting of works of art is, as you know, represented on your Board of Regents by our Vice-President Mr. S. W. Weis. One of our strongest artists, Mr. B. A. Wikström, has just died in New York where he was called to design the "floats" for the street parade of the Hendrik Hudson Tercentenary. He had for a quarter of a century been engaged in designing New Orleans Mardi Gras parades. His marine painting is an important contribution to the easel art of the country and will hold its reputation.

The standard of our annual exhibitions is fully up to the usual American standard and some twenty or thirty local artists gain admission. A large majority of these have received the benefits of travel and education in Europe and Northern centres. A gold and silver medal are annually given for the best work of local artists. R. B. Mayfield and A. J. Drysdale are holders of the gold medal, both for landscapes.

The leading force in Art Education in the Gulf States is the Tulane University of Louisiana, New Orleans, which included art instruction in its curriculum from the time of its establishment as the reorganized University of Louisiana in 1884. A very liberal policy in giving free instruction at that time made it one of the first wide fields for extension work, now so generally recognized in college activities. The later 
establishment of the H. Sophie Newcomb Memorial College for Women furnished a home for what has grown to be one of the most important college art departments in the country, in many ways. One limitation, that of excluding study of the nude, shows the state of thought as to education of women obtaining in a largely Catholic community remote from the currents of creative art. No doubt, however, this feeling will wear off, even although in a way creditable to the community, which shrinks from some of the liberties being accorded modern women. Medical education has so far been denied women in Louisiana. However, one of the professors of art has supplied the demand for instruction from the nude in his own studio for years, and as the Women's College is to be entirely rebuilt, it will soon arrive at a point where full facilities will be given, but it is to be hoped that a certain delicacy characteristic of the South will be long preserved. A faculty of seventeen professors and instructors in art, drawing and handwork, is employed by the Tulane University and 66 per cent of the students of Newcomb College attend art instruction.

This College has, as is well known, taken a position in advance, in that it has established a manufacturing pottery in which the graduates and students of the school produce the wares, and it also maintains agencies in large cities, doing the business of selling in the absence of any art industries in the locality which could furnish suitable employment or opportunity for art development. This pottery has been in operation nearly twenty years, and its success has won recognition at expositions, in bronze, silver and gold medals granted.

Its department of embroidery, more recently established, is important and shows a firm artistic handling of units of design. All of the art-craft work depends on Southern flora for its inspiration, and flowers can be had every day in the year.

The new department of architecture in Tulane University is expected to exercise a strong influence in art development, and special attention will be given to the local Colonial buildings of Louisiana which are strong in picturesque qualities as is indicated in the writings of Mr. George W. Cable, and in Mr. 
Joseph Pennell's illustrations for the same, not to mention the recent work of other artists.

The last few years have seen a great improvement in the architecture of the buildings erected in the South, as the taste displayed in the period following the civil war was not of a high order. There were a few buildings of a scholarly type erected in New Orleans by James Gallier just before the civil war, notably the City Hall, a fine classic design in marble following the order of the Erectheum at Athens.

We must now mention some of our deficiencies. We have no sculptor established in the Gulf States and there is not a single important example of mural decoration as yet. A few days ago I saw men painting the bronze statue in front of the City Hall and the glistening surface seemed to give the painter a feeling of satisfaction. The old Cabildo had its sculptured flag in the pediment group, picked out in stripes by the Commissioner of Public Works, who affixed his name to the pediment, which dates back to French and Spanish occupation, in block letters which can be plainly read from the street.

I do not think New Orleans the only city, however, where such poor taste and judgment is displayed. The city which calls itself the Winter Capital of America, and not without proper claim, is richly endowed with hospitals and libraries, but has as yet no public art gallery, although the small galleries of Tulane and Newcomb Colleges are open to the public freely, and in them the annual exhibitions of art are often held. There is then a splendid opportunity for a memorial endowment, and also for the school of architecture which is not yet properly endowed, although struggling hard for recognition and doing good work.

It is significant that the Cotton Centennial Exposition of 1884-5 left the city an Horticultural Hall, where other expositions have left art galleries. The lawns there are green with winter grass and the palms and live oaks render the streets so attractive as to lessen the importance of art collections in the judgment of the people.

The Louisiana Art Teachers' Association has been in active work some fifteen years and circulates an exhibition of work 
throughout the state on request, besides holding monthly meetings. A chapter of the American Institute of Architects is being organized, and a Tree Society is actively at work. A City Beautifying Committee of the Progressive Union has begun meetings to consider enlarged plans for the city and several committees are engaged in furnishing statues in memory of southern men of note, including Jefferson Davis.

It remains then to be said that we of New Orleans will welcome any plan to help us secure important art exhibitions for a southern circuit, and we will be glad to serve the nation at its Capital, if opportunity offers.

As a direct result of the London Congress, I have arranged for an exhibit of sketch designs in figure compositions from the students of Professor Moira, Royal College of Art, South Kensington, which will make a circuit of leading art schools at small expense. (Applause.)

At the conclusion of his address Mr. Woodward exhibited rapidly a number of paintings which he had made of buildings in New Orleans, purposed as historical records. After which the convention adjourned until the following morning. 


\section{FIFTH SESSION.}

\section{Thursday Morning, May 13, 1909.}

The Convention met Thursday morning at 10.30 o'clock in the Red Parlor of the New Willard Hotel. Mr. F. D. Millet, Secretary of the American Federation of Arts, in the chair.

The Chairman. It devolves upon me, in the absence of the president and vice-presidents, to preside. The regular order of business is, I understand, the report of the Committee on resolutions, of which Prof. Mitchell Carroll is chairman.

Prof. Carroll. Mr. Chairman, I have four resolutions to report. The first two are as follows:

Resolution in Favor of the Adoption of a Systematic Plan for the Development of Washington City.

The American Federation of Arts, appreciating the fact that the plan for Washington City was the greatest artistic legacy left the country by George Washington, that the beauty, fitness and harmony of this plan had no precedent in an existing city, that the harmonious grouping of buildings, treatment of parks, and location of statuary, as indicated on this plan, forgotten and ignored for seventy-five years, would have made our capital the most notable city of the world in artistic beauty and harmony, therefore,

The American Federation of Arts considers it the duty of our people and of our Congress, as a legacy to future generations, to assure the development of the city as suggested in the map of L'Enfant, and to secure in all and future additions harmony with the original plan, to parks and streets and the grouping and design of all buildings and monuments, therefore, be it

Resolved, That the American Federation of Arts urgently requests Congress to adopt a systematic plan after the best expert advice, for the future development of the District of 
Columbia, and to direct all future park treatment, location of statuary and buildings to be executed in harmony therewith.

Resolution in Favor of a National Bureau of Fine Arts.

The American Federation of Arts, appreciating the fact that all the civilized nations of Europe have systematic methods, under expert guidance, for acquiring and executing matters pertaining to the fine arts, and have a continuous policy to obtain harmonious; lasting and beautiful effects; and as the civilization of a nation, its education and refinement are measured by its art expression, and as our government has no system by which this expression of the people may be guided or have a proper growth, therefore, be it

Resolved, That the American Federation of Arts respectfully urge Congress to approve a bill for a Bureau of Fine Arts, controlled by a Council composed of experts and laymen.

Each of these resolutions being taken up separately and unanimously adopted, Prof. Carroll proceeded:

Prof. Carroll. In the adoption of the Constitution yesterday, we voted that Washington should be the headquarters of the American Federation of Arts. Fortunately for us and the other great national bodies of the country, there is a body of patriotic women who have it in mind to provide a home for the artistic and scientific societies of Washington, and I desire to read a resolution of the Board with reference to that.

Whereas, the George Washington Memorial Association, incorporated in the city of Washington in 1898, is raising a fund for the erection of a building to be known as the George Washington Memorial Building which, as its circular states, "will be dedicated to the diffusion of knowledge in all lines of human activity that will conduce to the advancement of the welfare of mankind," and

Whereas, this Memorial Building "is to be planned so as to furnish a home and gathering place for National, Patriotic, Scientific, Educational, Literary and Art organizations that may need such accommodations, including the Washington. Academy of Sciences and its sixteen affiliated societies," 
Resolved, That the American Federation of Arts join with the National Academy of Sciences, the Washington Academy of Sciences, the Association of American Physicians and other national bodies in commending to its federated organizations the noble and patriotic object the George Washington Memorial Association is promoting and pledges its hearty co-operation.

Resolved, That the officers of the National Art Federation be asked to adopt a definite plan to bring the aims and purposes of the George Washington Memorial Association to the attention of the members of the National Academy of Art and other organizations represented in this Federation, and request their support.

Prof. Carroll (continuing). Mr. Chairman, I move the adoption of this resolution, and we have present with us the Vice-President of the George Washington Memorial Association, and I am sure that all should be very happy to have a word from her.

The resolution having been seconded the Chairman called upon Mrs. Walcott for remarks.

MRS. WALCOTT. I only ask for the support and interest of the members of the Association in our work, and I hope later, as this Federation of Art grows, and you have here in Washington your conventions-national conventions and also international conventions-you will feel the need of a large permanent home, and that is what we are earnestly hoping to erect. Mrs. Dimock is our recently elected President, and is full of enthusiasm and zeal as to co-operation. (Applause.)

The resolution was then voted upon and adopted.

Prof. CARroll. I have one more resolution which I present at the request of Mr. Ellicott:

Resolved, That it is the sense of this Convention that the opening of the Vista bounded by the Via Nuova and the Burgo approaching the Church of St. Peter's at Rome from the Ponte St. Angelo, as illustrated by the diagram herewith submitted, is an object worthy of the support and advocacy of art societies throughout the world, and that we recommend the formation of committees who shall co-operate in trying to bring it about. 
After a brief discussion this resolution was set aside for the consideration of a committee, to be appointed later.

Mr. Henry Read then presented the following resolutions which were duly seconded and adopted:

Resolved, That the American Federation of Arts respectfully tender its thanks to the President of the United States and Mrs. Taft, Mr. and Mrs. Hennen Jennings, and the Board of Trustees of the Corroran Gallery of Art, for generous hospitality extended to its members while assembled in convention at Washington, and give expression to its appreciation thereof.

Resolved, That the Secretary be requested to send copies of this resolution to the President of the United States and Mrs. Taft, Mr. and Mrs. Hennen Jennings, and the Board of Trustees of the Corcoran Gallery of Art.

Prof. Carroll. There is one more resolution which will be presented by Dr. Needham.

Dr. Needham. Mr. President, those of us who have been in this city for some time, connected with this movement, leading up to this meeting, remember with great affection and admiration the life and efforts of Mr. Charles M. Ffoulke. It was at his house that the bill for the Academy of Arts was presented, referred to by Senator Root in his address; it was in his house that the preliminary meetings were held that have led up to this meeting and to this Federation-they were held in his house, because for many years he was a great sufferer, unable to leave his house without being carried, but all the time interested and devoted to the development of art and artistic taste. These meetings, therefore, were held at his house and this meeting was planned there. On the $23 \mathrm{~d}$ of April we laid him away to rest in Rock Creek-a man of wonderful patience and heroism in the bearing of pain and trials, but with it all a cheerful, patient lover of art and a man who looked out upon the world with pure affection. It seems to me, therefore, proper, Mr. Chairman, that I may offer this resolution, to be spread upon the records of the meeting:

Resolved, That the American Federation of Arts receives with profound sorrow the announcement of the death of Charles M. Ffoulke, and desires to express, upon the records of this 
meeting, its high estimate of his character, and his knowledge and interest in art productions. Mr. Ffoulke was one of the regents of the American Academy of Arts, which originated and planned for this meeting and this organization. He exerted a wide and beneficial influence for the promotion of the fine arts and devoted much of his energies to the collection of works of art of exceptional beauty and worth. With all he was marvelously patient and cheerful, bearing his bodily ills with true heroism while actively exerting his influence and using his talents for the development of a true artistic taste in home and civic life.

Resolved, That in Mr. Ffoulke's death this Society has lost an esteemed and useful member, and the City of Washington a citizen who was actively interested in its beautification along comprehensive and artistic lines.

Resolved, That the Secretary is hereby requested to send a copy of these resolutions to Mrs. Ffoulke and to the press.

Following the adoption of these resolutions, the Chairman introduced Mr. E. J. Parker, president of the Quincy (Ill.) Boulevard and Park Association, who spoke on "What Can Be Done by Co-operation for Outdoor Art." 
WHAT CAN BE DONE BY CO-OPERATION FOR OUT-DOOR ART.

\author{
ADDRESS OF
}

Mr. E. J. PArker.

Mr. Chairman, Ladies and Gentlemen: When my friend, Mr. William E. Curtis, asked me to come to Washington to speak, I declined to have my name put upon the programme. However, I appreciate what $\mathrm{Mr}$. Curtis is doing-traveling all over the civilized world, giving us daily in the columns of the Chicago Record-Herald the benefit of his observation, experience and keen insight into matters. I wish you all could read his letters as they are daily printed, and also see McCutcheon's cartoons in the Tribune. But you cannot all live in Chicago, I regret to say, and you have our sympathy in being confined to the Atlantic Coast. (Laughter.)

In speaking on the matter of organization, it seems to me that the highest expression of the results of organization have been realized in our country by the great expositions which combined talent and experience, and which have had such an important influence upon the development of art in the United States, namely: the Centennial Exposition at Philadelphia, and others following at Atlanta, Chicago, Omaha, Buffalo, and St. Louis. It was my privilege to visit nearly all of them. Sunday last when I crossed the bridge on Connecticut Avenue, I believe, I wondered then whether the magnificent Alexander bridge in Paris had any influence in the building of that structure, rather than an iron truss bridge.

However, organization can never wholly take the place of individual effort and initiative. We will shortly return to our homes and begin again an effort in our communities where it can be put forth more easily and with greater results than in any country on the face of the earth; for have we not the purest democracy here? There are no class distinctions to prevent an American, or a foreign-born man coming to our shores, from almost immediately coming to the front, if he has ability and taste. Nothing can take the place of private initiative in our country. Fifty-seven years ago there was no 
municipality in the United States which had purchased an acre of land for park purposes. In my boyhood days, in Boston, I used to put on my skates within about 125 feet of Charles Street, where the Back Bay improvements were made, and, I think, under Governor Banks' administration. Only those who have lived in Boston and know more or less about the city, can realize and appreciate the changes which have been macle. I am inclined to think that the filling in of the marshes there gave the first impetus to what we are working towards, and which is the climax of all our work, namely, the civic center, the grouping of public buildings. Not only is magnificent Commonwealth Avenue established and followed by others in our country, which I will name shortly, but there was perhaps the first grouping of buildings on Copley Square: the Public Library ( $I$ will not name them in the order of their erection), Trinity Church, the Art Museum, and other fine public buildings. What a dignified open space there is at the entrance of Central Park, New York.

When the American Park and Outdoor Art Association was formed, Professor McBride, President of the Iowa Forestry Association, a charming man, made this statement in the City of Louisville; that during the French Revolution France was bare and bald of beauty (there is a direct connection between beautiful surroundings and patriotic sentiment). Under Baron Haussmann and Napoleon III. Paris was changed; and coupled with that statement I remember the words of $D$. $H$. Burnham that every year more money is expended by visitors to Paris than all those improvements cost. I do not forget what Ambassador Bryce said the first day of our session about some of the picturesque features of Paris being removed. You must remember that one thing was possibly held in view all the time by the Government, that in case of revolutions they would have large open spaces where they could use their artillery. While some criticism might be made regarding the formality and uses of the Place de la Concorde, and Champs Elysées, yet the Bois de Boulogne is a remarkable park for such a large world center as Paris, and has many natural and attractive features. 
In connection with the development referred to which was going on in Boston I will speak of one citizen who was once a candidate for the presidency, namely, Samuel J. Tilden, a man of unusual organizing capacities. He was at work securing the legislation for the splendid Riverside and Morningside Drives in New York, and possibly for the construction of Central Park.

The Civil War retarded the development of parks in our country. With the vast amount of money made by individuals, the building of residences, business and manufacturing buildings went on very rapidly. Unfortunately the mansard roof came in, and a great many hybrid styles of architecture; but there is a survival of the fittest, and today they are, since the Renaissance, so to speak, going back to the splendid Colonial houses and structures of New England, and especially of the South. Only last week when in New York I visited the National City Bank, which illustrates the easy adaptation of the splendid old Colonial structures to enlargement and improvement. I hope you may all see this building.

In considering Senator Root's statement of the objects of this Association, how insignificant we feel as individuals. How much there is to do! How late we have been in this country in commencing the work! We all realize now the benefit of organization.

The panic of 1873 checked improvements and enterprises by individuals. At the same time, with the power of taxation, there began to be an increase in Government and municipal improvements-especially in the development of park systems. Cities could do, with their power of taxation, what individuals could not, as incomes were affected. Fortunately the great transcontinental lines had been built which has made it possible for the Government to make reservations and national parks, and most fortunately, forest reservations.

The first and most important public work in our country, from the standpoint of art, is the carrying out of the plan designed by the Commission, viz.: Messrs. Burnham, Olmsted, McKim, and the lamented St. Gaudens. There come to Washington every year representatives from the whole country. And here you must think of Mr. Root's statement: To carry 
on our work means votes and money, and people who are not artistic, either by temperament or taste, are to be educated. We have many practical questions to face, fully considered and expressed by Senator Root in his remarkable paper regarding the objects of this Association. The first lesson taught me by a landscape architect was this: "Remember that human life is short, very short, in comparison with the life of a city." We must all do as much as we can in anticipation of the longer life of a city. There will be work for coming generations to do which we cannot accomplish now, for this Federation will survive.

To illustrate the development which may go on in a single city I will mention again the Back Bay improvements in Boston, with Commonwealth Avenue, Copley Square, the magnificent bridges over water spaces, now followed by the magnificent buildings erected along what is known as Back Bay Fens, the further development of the Metropolitan Park system, the Middlesex Fells, the Blue Hills, and other reservations for future improvement.

I think there is one name which this Association ought to consider for honorary membership, that of President Eliotinterested in all matters pertaining to the development of artand whose lamented son, Charles Eliot, had the wisdom and capacity to consolidate (for the purpose of increasing revenue by taxation) eighteen towns in Massachusetts into the Metropolitan Park System. I am glad that there is such a substantial memorial erected on the reservation at Blue Hills to the memory of Charles Eliot.

If the plans of the Commission can be carried out, the plain Senator and Representative coming to Washington will learn a lesson in correct and artistic improvements.

The next step, it seems to me, to be taken, will be the commencing of the improvement of all public grounds about the State capitols. I will mention only two State capitols. Take Hartford, my native city. Many people ridiculed the efforts of the Rev. Horace Bushnell at the time he proposed to begin the park improvements in Hartford. There stands today in Bushnell Park that splendid State House. What a site for that noble building! St. Paul has a beautiful State House, 
but the grounds surrounding it are not yet embellished. The State of my adoption, Illinois, has an expensive capitol, but its surrounding grounds have not been improved. However, I am not giving the Governors any rest, and shall not, until something is done. The local Park Commission of Springfield has not included it in its improvements. (Applause.)

So from one end of our country to the other let us keep at work until the grounds surrounding every public institution shall have some improvement in landscape art.

When I was President of the American Park and Outdoor Art Association, I wanted to do something practical, and I felt that a step taken in my official capacity, of course, would be much more important than anything that I could do individually. So I issued a circular to the Mayors of every city in the United States suggesting that they could easily improve the grounds about all city and public properties. I also addressed a letter to every railroad in the United States with reference to beautifying their terminals. I was surprised when I got through with our mailing list to find that there were 995 railroads. Mr. Stuyvesant Fish, then President of the Illinois Central Railroad, sent his engineer to Quincy, as I wanted him to do, to see what we had done in the matter of providing for the care of water on steep surfaces in our parks and parkways. I suggested to the engineer that the railroads ought to begin to raise the timber for their ties along their reservations. Some of them are doing it now; among others the Illinois Central.

As I said this morning to Mr. French of the Art Institute, in speaking of our annual meeting in Chicago, we had heard from Mr. Patterson of Dayton, Ohio, and some of you know what he has done in embellishing the grounds of the National Cash Register Company. I noticed a lady sitting near me who was somewhat uneasy, and she was suffering that agony referred to by Mr. Leslie M. Shaw at the banquet of the Indianapolis Monetary Conference when he said: "There is no agony at all comparable to that of an undelivered speech." (Laughter.) The lady, Mrs. Herman J. Hall, of Chicago, rose and said that we were making a mistake in not mapping out work for the women. She only spoke about three minutes, 
and it was an illustration of a woman's convincing every person present. We founded the Woman's Auxiliary of the American Park and Outdoor Art Association, and Mrs. Hall was made its first President. From that time on the Auxiliary has done most effective work in many cities.

I was asked to write a paper. If I had written one, I would have torn it up fifty times over. I would not write a paper to be read before a body of specialists and trained men; for I knew that I was incompetent to do it. Therefore, I did not attempt it, as it would have seemed presumptuous. I should have been very glad to have spoken in support of the resolution approving the Commission plan.

In writing a paper on the founding of our Federal City, I found it very difficult to get at historic facts. I have been no more surprised at the battles fought, the achievements gained in diplomacy and statecraft by General George Washington, than at his wisdom and foresight in employing the first landscape architect in our country in establishing and laying out a Federal City in the District of Columbia. There was great competition for the location of the Federal City, and by the merest accident it was located here. In Philadelphia and elsewhere the competition was sharp, and acrimonious debates in the Congress of 1783 led to the determination to have the Federal City free from State control and commercial influence. So it was located here by the wish of General Washington.

Mr. Curtis has spoken to me two or three times about our endeavors to get Speaker Cannon to come round to support the Commission's plan. I told him that I had written to $\mathrm{Mr}$. Cannon a good many times, and I now close by reading the closing paragraph in my letter addressed to $\mathrm{Mr}$. Cannon in 1902: "In the United States we are coming to nobler expressions of art and architecture, and the Government is recognizing the fact in the improvements made at Annapolis and contemplated at West Point. But in the District of Columbia is the Nation's opportunity to illustrate the gospel of 'beauty with utility,' and on an imperial scale. There we should have the 'maximum artistic qualities' expressed in the united arts 
of architecture, landscape gardening, sculpture and mural painting." (Applause.)

At the conclusion of Mr. Parker's address the Chairman called on Mr. E. T. Hartman, Secretary of the Massachusetts Civic League, to read his paper on "Some Aspects of Municipal Art Development," which had been postponed from the previous session. 


\section{SOME ASPECTS OF MUNICIPAL ART DEVELOPMENT.}

\section{ADDRESS OF}

Mr. Edward T. Hartman.

Mr. Chairman, Ladies and Gentlemen: I have no written paper for reasons similar to those mentioned by Mr. Parker; I agree with Mr. Parker and I can express my agreement in the words of a friend of mine who said that he would "rather be an extemporaneous ass than a premeditated fool." (Laughter.)

I am not an artist; I am only a civilian. I use that word advisedly, after yesterday. But I know that what we want is co-ordinated action, then our results will be much better, and there is a better chance that they will be artistic.

Now we have come here as a lot of individuals, knowing art, or sculpture, or architecture, or some other one thing; but the work we do as individuals is not going to build any American community. And it is the American community that I want to talk about; its form of expression, its method of telling to the world what it is, what it believes, and what it can do; because until we can get the people back of community work we are not going to do very much. We may have interesting statuary and paintings in our art museums, and a few interesting individual bits elsewhere, but until our American cities are more uniformly artistic, until they more uniformly express what is within a people to be expressed, they will be unsatisfactory. I may say that it is only by expression that we advance; it is only by doing things that we learn to do things; it is only by the effort, the conscious effort, that we are ever going to arrive as American communities. I was fearing that this new movement might deal entirely with the work of artists, in the individual sense. We must keep our communities in mind. We must recognize that until we can get the whole mass of the people back of everything we are doing, that we are not going to accomplish very much, and for that reason I like to use the title, "The City as a Form of Expression." The city is the ultimate. The city is 
the ultimate result of the work of the people of the city; and we can judge for ourselves of the crudeness of the American people when we look at the crudeness of the American city. There is not a city in this country that is a finished product. Mr. Cable will express himself in one form and give us a finished product; Mr. Millet will in another form; a sculptor will in another form, and each will supply a finished product. But it is the work of an individual, and that is not going to generally improve any American city.

But, to go back to my original point, that where a lot of people instructed from the art standpoint attempt to do something together, they often do it in a most inartistic way. This is characteristic of all of us when we attempt to do anything in our American cities by community processes; we fail simply because we have not learned to work together, and until we can learn to work together, until we can put the mass of the people back of these movements we are not going to accomplish much.

It is suggested that I could perhaps illustrate this by telling what some of our improvement societies have done in Massachusetts. They have none of them done ideal work, but they have done something, and I am going to show in a concrete way what they have done, because their work represents community work. I can preface this by the statement that those communities have grown more in the doing of the little things they have done than they have grown in a hundred years by other processes. Our political parties pull us apart, our churches pull us apart-everything that we have, and have had in the past, seems to have been developed for the purpose of pulling us apart. We like to fight; and it makes very little difference whether it is religion or politics, or what not, we will fight over it. But here comes this non-partisan, non-sectarian, public-spirited movement, for the development of our American communities. The idea itself, the mere concept of a general improvement association, is one of the most beautiful. We have not attained it in any other direction, but we are going to attain it in this direction; and I think that the development of these organizations is an indication of the drift the American people are now taking. 
In one of our towns of about 10,000 population they held an annual Old-Home-Week celebration. The executive committee at one of its meetings said that it would like to do more than have an annual explosion; it wanted some advice as to how it could make the thing permanent. They wanted somebody sitting on the watch all the year round for the good of the community, to fight for the community. They were advised to form a local improvement association. They called it a "Civic League," and they asked some one to go over the town, study its needs, tell then what should be done first, so that they could go directly after some one thing at the start. They were told in a lecture, illustrated by stereopticon, that one of their first needs was a playground. It simply happened to be the thing most prominent. There was not a place in the town where boys could play a game of baseball without committing an act of trespass. They had thought they were in a good condition; but they realized that they were not, and that it was a critical situation. They went to work, organized their league, and within two months, to a day, at a special town meeting, appropriated $\$ 9,000$ to buy a fifteen-acre playground within easy reach of everybody in town. That was the start. They went on. They took a beautiful natural promontory for park purposes, and the way they did it was interesting as a community movement. This promontory ran back from the level land. The town was built upon the level land, the people owning the land in strips that ran back over the hill. Many of them said they would give their portions of the land that they could not use for farm purposes; others said that they could not afford to give it, but that they would sell it at a nominal price; and the others said, "Now we have you." But they were answered, "No; but you haven't. We will take the whole in the name of the people." And they did. The matter was settled in the courts and the people who tried to squeeze the community got just about what they ought to have had.

Then they went to work and cleaned up the town. A lot of refuse heaps were removed; the street trees were cared for, the street signs were replaced with more artistic 
designs. And one of the most beautiful residences on the main street was secured for library purposes. They did a number of other things, until finally one of the leaders said they had to manipulate the adjournment of a town meeting, in order to prevent the town from bankrupting itself for improvements.

This movement has been going on there for about three years; they have done it all in that time, and there is no community that cannot do it when the people get back of the work.

There is another illustration that is very interesting, I think, and it is an illustration of an artistic method of conducting a celebration rather than of producing an artistic physical result. It was a Fourth of July celebration. I think we could take our civic work into that field just as well as we can into the development of beautiful physical objects. The people in this town wanted to have a Fourth of July celebration-a celebration which would be more than smoke and powder and noise and nuisance, something that would be a real expression of the people. They started out by asking for money, from every man, woman and child in the town. The mill owners were allowed to give not over ten dollars each. They were very wealthy men, but the children in the schools and the children of the mill workers were asked to give five or ten cents, and they did, practically all of them; there were thousands of them that did.

When the morning of the Fourth came, practically every individual in the town had an invested interest in the celebration. They proposed to see that it was a success. And it was. Everybody was in it in some capacity, in the parade or in the observance of the day. The leader of the Russian Jews, who always filled himself with beer on the Fourth of July, was in charge of his people. He was their natural leader, and he led them through the parade and performances of the day with the greatest success. All kinds of people had been brought in through their leaders, just as the politicians bring in the people. As one of the managers said, "These leaders are the kind of people the politicians try to get hold of ; but 
they will not get hold of these, because somebody else got hold of them first."

That celebration was an artistic expression in every sense of the word. Sick people were pointed out by the physicians and, as by magic, a circle was drawn about each home, and when the parade came to it the noise ceased, and at a certain other point was taken up again. That was artistic. The small boys of the town-about two hundred of them-the kind that are generally ignored and kicked out and virtually told to raise the devil all day long, were called together. They were dressed in costumes that fit boys when they want to have a good time, and they were placed in charge of the rowdy of the town, an enormous fellow, who always got drunk. He did not know how to do anything else, as a matter of fact he had never been asked to do anything else. They placed him in charge of these boys, and dignified his position by the expenditure of $\$ 2.65$ for a gorgeous uniform. Well, he felt the importance of the occasion. He took charge of those boys and carried them through the parade with the most absolute success, and when evening came he was as sober as any of them. And the police gathered that evening on the town hall steps lamenting the fact that it had been the dullest day in their official career. (Applause.)

That is what I call an artistic expression by the people of a community-not the artists, not the politicians, not the ministers, not the teachers, but the whole pepole; and until we can get at it in that way, and until we can make our cities, physically and spiritually, the form of our expression I believe we are not going to make any great headway. Now, that is the idea.

I should like to say just a word about the type of organization that is coming in to do this work. As I said, it is the improvement association-the grange, the women's club, the non-partisan organization of whatever type it may be. We have in Massachusetts upwards of a thousand organizations among those groups; some two hundred and fifty women's clubs, over two hundred granges, and numerous improvement associations. They have great possibilities. 
Take the women's clubs. I take them because they are the best organized group in our State outside of the Grange. The Grange is more slowly coming into this movement. The women's clubs, you all know-and that is an interesting item of history-in the old days gathered themselves together in the most aristocratic parlor they could find among their members, and studied Shakespeare or Browning and similar studies, and then went forth superior to the world, cultured and indifferent, not caring much about how their neighbors got along, rather inclined to ignore them. They are now finding out practically and effectively that to take up community problems, and to solve them, gives them more of culture, more of personal advancement, more of real advancement than the other process; and so the women's clubs are coming in in enormous numbers, and are taking up work of this kind.

I clipped from the Boston Herald of Tuesday morning this little editorial. It sums up the entire story, I think, for it is headed, "Woman's Part in Civics."

"Foregoing the divisive issue of suffrage, one State federation of women's clubs has adopted a practicable working programme for the coming year. Its plans include a concerted fight against billboard advertising, establishment of comfort stations in all cities, investigation of the treatment and care of delinquent girls; a crusade for a saner way of celebrating Fourth of July; procuring women physicians for all institutions which have women inmates; reservation of the pine woods of a certain county as a State forest preserve, and a campaign to secure forest reserves in the Appalachian and the White mountains. How sensible, yet up to date and legitimate. This is a typical programme of an average State, indicating what a vast number of women enrolled in the National Federation of Women's Clubs are interested in beyond and above "society." It is a dull legislator and executive today who is not alive to the fact that his action on issues of State is keenly watched by the American woman."

I have repeatedly asked women in Boston to write to their Senator or Representatives on some question, and they come back at me with, "I am willing to write, but why should I write 
when I cannot vote?" You go to the women's clubs and talk to them about the billboards, and they reply: "Why do you talk about anything like that until we can vote?" As I said on one occasion, most of the billboard advertising appeals to the women-the larger percentage of it-than to any other class of buyers; and if they would simply see and observe, and, having observed, act, the billboard nuisance would become very soon a matter of history and the billposters would have an opportunity to illustrate that great American trade of mobility in labor. We care not how soon that may be brought about.

This group of individual organizations has it, therefore, in its hands to lead in this general movement for thorough community work; and that is all there is to be said, I think, on this subject. I thank you. (Applause.)

The Chairman. It is very encouraging to hear such an optimistic address as Mr. Hartman has just made. I notice only one note of pessimism, where he spoke of the crudity of the cities of the United States. I think crudity is sufficiently distributed, as far as my observation has gone, in European cities and elsewhere, not to cause us to be altogether disheartened. In a recent trip to Japan I found some of the crudest things I ever saw in my life, in Tokyo. And speaking about Rome, it is only necessary to recall the great new Palace of Justice in Rome. We have crudity all the time. As I have said, constant vigilance is the price of beauty. You have got to watch it all the time.

Now, I take great pleasure in introducing Mr. J. Horace McFarland, of Harrisburg, Pa., President of the American Civic Association, well known to us all. (Applause.) 


\title{
HOW THE AMERICAN CIVIC ASSOCIATION PROMOTES COMMUNITY BEAUTY.
}

\author{
ADDRESS OF \\ J. Horace McFarland, \\ President American Civic Association.
}

Mr. Chairman, Ladies and Gentlemen: I am to speak to you, I believe, on "How the American Civic Association Promotes Community Beauty."

First, it is not unfair, possibly, to consider whether beauty is valuable in a community or to a people. We insist in our very title, which is the "American Civic Association for a Better and More Beautiful America," that public beauty is influential, first, on the daily life of the people in the most gratifying and important way; that it tends expansively toward the prosperity of a people, and that is our American ideal, surely; that it promotes most admirably efficient industry; that it greatly increases the public order, to keep which we spend vast sums of money. And here I will digress for a moment to say that last Saturday I saw the parade of 5,000 policemen on Fifth Avenue, New York, devoted to keeping public order; and I was able to tell the ladies and gentlemen who were gathered at the New York City Club's Civic luncheon that last year a million and six thousand people were kept in order in the parks of Harrisburg by seven policemen, who in one year made ten arrests! I contrasted the difference between the ugliness of the streets which excited disorder and the beauty of the parks which promoted good order and sane life.

I insist further that beauty is valuable in its effect on travelers incoming to any community. And I again digress by saying that for a good many years-and this is just a little pessimistic-the United States has been doing the anomalous thing of destroying as much beauty as it could of that bequeathed to it by the Creator, and of creating as much ugliness as possible in the structures required in the process, in order that the people who destroyed the natural beauty and created the 
ugliness might use the commercial increment thereof for travel to Europe to see natural and artificial beauty! (Applause.)

I insist, also, that beauty about us-both natural beauty and city beauty-promotes in the highest way the patriotism about which we sing, but to maintain which, we do not work very hard. We sing, "I love thy rocks and rills," after we have painted the rocks with suggestions to buy a toilet powder; and have given up the rills to the private advantage of some man who has a mill to drive. We speak of the glory of our mountains, after they have been dragged down from their heights, that the very heart of them may be ground up for private advantage at a rate of a thousand times greater than the true demands of the country require. We forget that it is only the beauty of a home, a street, a town, a country which promotes that love which is the basis of true patriotism.

Mayor McClellan, of New York, has said: "The city healthy, the city wealthy, and the city wise, may excite satisfaction, complaisance and pride, but it is the city beautiful that compels and retains the love of her citizens." Some one else has wisely said that "no nation ever took up arms in defense of a boarding house" ; yet a good many of our American communities have been fostered and built up upon purely boardinghouse lines.

Now, if beauty is infuential on life, it is worth considering in detail; and I know this assemblage will agree with mefor that is the very essence of its being here-that life and beauty ought to walk together, hand in hand.

The details that treat of the American Civic Associationand let me say here that while I shall be giving perhaps what seems to be a prospectus; it is not so; it is merely the history of what actually has been done and is being done-include every little item which promotes intimate connection with community beauty.

The home, first; for when we treat of the exterior of the beautiful home, we deal with surroundings which are most immediately influential in the creation of community beauty, and in that effect upon human life which tends to make the most efficient citizens. Therefore, we constantly promote in 
our work a consideration of how well adapted to the creation of beauty, even in sordid surroundings, are the plants and trees and vines which God has given us so abundantly in America. When we come to consider how influential just one little plant may be, we can realize that these growing things have much to do with real community beauty. A few years ago I was placed by the Civic Club women in Harrisburg on a committee to judge a back-yard flower garden contest, following the giving out of seeds to those who would apply. We went to many homes and back yards; some of them elegant, many of them mediocre, and some dreadfully sordid, but we found that in one at least there had been used the true spirit. It was in the worst slum of the town, and when we hunted up the boy who was registered as a contestant we found him with his associates playing about a filthy street. Somewhat shamefacedly he led us to the unpleasant back yard in which his efforts had been exerted. His companions, following, jeered"O," they said, "Tommie's only done that one thing." When we came to the garden, we saw that what Tommie had done was to secure the prosperity of just one morning-glory vine; and when we saw what this meant, and told him about it, he was much the proudest citizen of "Sibletown." The influence of that morning-glory went over that dirty little slum.

Next to home surroundings, we must take into account the way which we get about the community. We may have highways bad, better or beautiful, as we please, and as we work from the home unit to the street unit, it is our desire that the street should be an orderly one; that it should be planned to be beautiful; that it should have the right width of traffic space, the right width of sidewalk; the right disposition of that grass which is certainly God's first aid to the injured American citizen; and the right aspect as a street.

Despite what has been said about the crudeness and rawness of the American community, I want to say to you that there are not only scores, but hundreds and thousands of community streets which have an absolutely concrete expression at this moment, typifying the desires and the love of the communities in which they are. (Applause.) Everyone of you knows that there is some home street in your home town which 
you regard as about right. These streets are fortunately not all alike; the street arrangement which is perfectly proper along the river bank in Harrisburg might be totally out of place if forcibly transferred to the main street of Amherst in Massachusetts; but each expresses the pleasure, the thought, the pride, and the love of the members of its own community -and we find such all over this country.

It has been my good fortune to speak within the last three years in more than 130 American communities, not farther west than St. Louis, not farther south than Houston, and not farther east than Portland, in Maine; and everywhere I find some one street to which I am taken, while they say, "This is a beautiful street," swelling with pride because the street does express the community desire and the community life.

We can have these streets better if we care to have them better, but we cannot have them better on any general readymade plan. They must express the desires of those particular people who, after travel, come back and create their own ideals in their own home streets.

Next to the street is the bridge. Mr. Parker has spoken of the magnificent Connecticut Avenue Bridge; and I speak of many bridges that $I$ have seen. At the moment there comes to my mind the half dozen bridges crossing the White River in the city of Indianapolis, to which people are constantly taken because they are especially beautiful; they are not simply efficient. I think of the quarter-million-dollar concrete structure which is now nearing completion in my own home city (following an iron abomination, which fortunately rusted and burned down), which has excited the admiration, the loyalty, and the efforts-through appropriations-of some of the most sordid councilmen of our city.

Ladies and gentlemen, the most ordinary of us does respond to the suggestion of beauty, and no one can truthfully maintain that there is not inherent in every American breast a continuous and always outbreaking love for beauty.

Last night I came to your city in company with a Congressman from a Western State. With him was a young man whom he said with some pride had been digging potatoes as a field hand ten years ago. He was now a man of some sub- 
stance because of his business ability. He had never been east of St. Louis. At the suggestion of the Congressman, we went to the top of the apartment building, even though it was then nearly ten o'clock, because from there there was a view of the Capitol, the Monument, and the Congressional Library. This young man, never having seen any part of the great Federal City Beautiful before, stood looking at it all in admiration, taking long breaths, and saying, "I am a better American citizen for having been here and seen even this little of it." And he was a potato digger ten years ago! (Applause.)

We inculcate love for the trees on the streets, because in the trees are one thing which rescues the street from the commonplace. Remove the ninety-three thousand trees from the streets of Washington, and you will all be ashamed of what is left. The American Civic Association is spreading abroad tree knowledge. It never suggests that you must put a maple here, there an elm, a poplar; but it says, "Consider the best trees for the particular climate, whether that be Galveston or Chicago, and put that tree there under the best conditions you can bring about. It proposes concrete, direct and definite laws for placing the control of trees in the public, and not under private carelessness. It follows the model of Washington; it takes up the excellent law of New Jersey, and has it passed in the State of Pennsylvania, where many communities are rapidly getting rid of their old, sordid shell of ugliness through the means of a new appreciation of beauty in other things, as well as in the trees.

We desire that all America shall be arboreal; that this Continent, which once had more than sixty per cent of forests, shall sometime or other have at least six per cent. In addition to the Federal and State work with trees we do the very best we can to promote practical, definite forestry. As evidence of that, let me tell you that the American Civic Association proposed and had passed by the Legislature of Pennsylvania a bill permitting communities in our State to establish municipal forests. Thus we have in Pennsylvania the beginning of the best adaptation of the forest, which makes it surround the community, giving to the community, first, direct 
increment of profit, reducing its taxation through the sale of timber products; and, second, that magnificent asset, that great help toward beauty and healthfulness, which only trees can produce.

We want also to see that the lighting fixtures which are in the city streets are made good to look at and not bad to look at. We want to remove the tariff against American youth which exists at the present time, and which Congress has not anything to do with. Parenthetically, please note that we have been educating our young men and young women in familiarity with astonishing ugliness all their lives, so that when those who have to do with the industrial fine arts need a boy or a girl who has knowledge of form or color, we can never get an American. We have to employ a young Frenchman or a young German, because these young people have grown up with some idea of beauty and appropriateness in the common things that surround them. But we want better lighting fixtures, and want them better designed. An instance of this demand is seen in Denver, where they have made definite and concrete effort to have their streets lighted pleasingly, for the effect upon the people.

We want, also, to have the entrances to such parks as are given to a city sightly, and not belittled by signs and billboards. We want that requirement to apply even to the Federal City, and we want the ignominy of a vulgar theatrical sign to be removed from the main entrance to the Capitol grounds, where it is today.

We believe in all great public structures being made beautiful, and particularly for school buildings; we bring to the attention of communities the absolute necessity of large open spaces about them, as well as of good architecture.

Several weeks ago I had the privilege of speaking in the very pleasing town of Montclair, a distinctly and peculiarly rural city community. You can scarcely imagine that it is near to New York. It has a population of twenty thousand people, almost all of whom work in New York, but who love the trees and the hills and the open spaces of Montclair. Unfortunately, they forgot that they had two sides of a magnificent educational quadrangle in two existing school buildings when 
they employed a New York architect to design a new school building. I think he went into the lowest cellar of the highest skyscraper, and there drew upon his imagination for the most beautiful building that he could devise to go on 46th or on some other New York street. Then he went out to Montclair, with his eyes shut to its peculiar beauties, and he planted that building about cornerwise to one part of this possible educational triangle. The building itself, I sujpose, was good, but when I went out to look at it, in connection with the present condition of the town of Montclair, I had to say in my address that it was an architectural wart! The gentleman responsible for it insisted that it was in the purest Italian Renaissance style! But I told him this was not an Italian Renaissance town; it was, thank God, an American rural community; with its own charming expression, and the Italian Renaissance building abominably hurt it.

I had sent to me, yesterday, the charming plan of a frame school building in Bethel Township, in Nebraska-a one-story structure, suggesting the open country. It is absolutely convenient inside, as its plan proved, and absolutely beautiful outside, as its aspect indicated. I found on investigation that it was the work of one devoted man who had beaten the architect into understanding and finally got a building that fitted the place and the country.

This is the sort of thing we stand for; we do not want city school houses in the country, nor vice-versa. Nor do we want city hall, libraries and theaters in small communities. Of course, this at once leads us to the statement that we constantly foster the grouping system, whereby one building helps another, whereby the whole tends towards co-ordinate beauty, and whereby you get a great deal more for the money-which we hope is an important consideration in the United States of America, as well as elsewhere.

We also want suitable community entrances, and we constantly worry about the existing conditions. Did the entrance to Washington please you? Were the surroundings dignified; were they expressive of all a nation of ninety millions of people could do for itself? Did you see unsuitable structures bumped up against the railroad any old way? Did you see the bill- 
boards? Did you see the sordid backyards, which if you had seen relatively the same thing in the window in front of a great department store would make you turn from that window and say, "We won't trade with you"? When I go into an American city I see, as I come in, how they have expressed themselves, or forgotten to express themselves. Nothing makes people sit up and take notice more than to show them by actual depiction by a lantern on the screen just how ugly their town must appear to the man who comes in or those who go through it.

And, most important of all, we call to the attention of communities the immense importance of beauty in waterfronts. We Americans have certainly disregarded the value of water scenery. We have considered that water was mostly useful to remove human wastes, and so we have made our beautiful American streams sewage tanks or open sewers; and we have made the banks, where we could get to them from a city, places for the deposition of unconsidered trifles like tin cans and other ancient and somewhat unpleasant things. But we are gradually waking up, and here and there one finds communities in which the whole town has expressed itself on the river front. I am reminded of the little town of Grand Rapids, Wisconsin, where the ladies determined that the banks of the river should no longer be a reproach to them. The city council had no money, but some men had, and they were induced to raise enough money to buy the river banks. Now they are in use by all the city, and they express something. The ladies found that a certain extensive flour sign had intruded itself upon this river bank. They wrote to the manufacturer of the flour that they would like to have those signs removed. Nothing happened, until about three weeks later, they wrote that they could manage to do without Pillsbury's flour until the signs were down! Instantly the manufacturer's ears were unsealed, and the signs dropped in a hurry. The people of Grand Rapids are maintaining the community expression along the Wisconsin River with complete success.

The American Civic Association must also do the work of fighting directly the outbreaking nuisances. We want to destroy the smoke, which itself destroys a natural resource that 
no man can replace; no man who distributes his wasted carbon over my collar and upon my pillow, and who covers my house with his nasty soot can make and replace one single grain of the coal he has thrown away.

So we insist that the smoke nuisance is unnecessary, uneconomic and wrong, and all over this country there is growing up a slow, vigorous and effective resistance. It is slow, but yet it is vigorous; it is reducing the waste of smoke. Smoke is one of the nuisances that will handle itself, because coal is growing scarcer and higher and men cannot afford to throw it away.

We fight the unnecessary breaking into the forests by the continuous erection of new pole lines. One of the most important helps we have in that is the electric companies, some of which, like the Bell Telephone Company, do not put up poles by preference, in cities. We insist on extending this work until the poles cease to draw upon the forests; and the wires go underground. But to that end we never propose drastic removal of the poles all at one time. Nothing could be more foolish than such a suggestion. We urge that main highways be freed from the poles; that main trunk lines of wire be put underground; that there be combined service between trolley and electric light and telephone companies, so that the number of poles shall be as small as possible. It is very gratifying to say that this movement is constantly gaining strength. Let me say that the pole nuisance will also take care of itself, because timber is so scarce that the telegraph companies cannot afford to continue putting up poles. Poles increase in price and decrease in life. The cost of maintaining a pole line is said to be eighteen per cent per year; the cost of maintaining an underground line, under the most expensive conditions, is given as only seven per cent.

But the other nuisance-the billboard nuisance-grows with industry, and unless we who are here and those whom we come here to represent, take some sharp action soon, it will be absolutely futile to form a national art federation, because your finest architectural creations will be used as the foreground or the background of an advertisement of some nostrum. Note, for instance, the way in which the Garfield 
Statue, at Maryland Avenue and 1st Street, is used to furnish a foreground for a breakfast food. Of what avail is it to erect a great national building anywhere, if a man, by right of what he calls divine possession, may come up close to it and use it as a background for his nostrum. Why is it fair for Mr. Carnegie's great marble palace on Fifth Avenue, New York, to be absolutely dominated by a two-story billboard covering the whole lot between that and the next building? So, I say there is the one, present greatest danger-the contintous extension of the billboard nuisance, which is a complete travesty on American liberty and right, for the billboard proposition is based primarily on special privilege which we are supposed to decry. The billboard man never erects his structure on land which he may have bought for that purpose, or in some secquestered location. He puts it where the people have spent the most money, so that he, like the parasite and leech that he is, may suck from the body politic some part of its increment, destroy some part of its beauty. I speak vehemently because I declare that the danger is great. Don't you believe it? The other day I saw on a sign in a street car this notice: "The moon as a billboard would be at a discount compared with the service we offer-New York Advertising Co." Are they not ambitious? (Laughter.)

We want to deal also with making good citizens, and that may well be done by getting the man, woman, boy and girl outdoors into the parks. It is not so long since the conception prevailed that parks were a public luxury that were created primarily to have flower gardens and stone dogs and iron fountains in them; nor so long since the "Keep off the grass signs" were plentiful. Those signs have fallen for the most part, for we now know that grass is made for three purposes: To be looked at, to be walked upon, or to be grazed. We know that it does better when it is used by humanity. We want plenty of these open spaces and parks, and we propose to communities to provide something like the proper average of an acre for every one hundred of population. Last Saturday afternoon there was a shudder in the City Club of New York when it was shown by the authorities that they had but 
one acre of parks for each 1,316 unfortunates confined on Manhattan Island; and the costliness of their hindsight was shown in the comparison between Central Park, costing a little over five million dollars for 800 acres, and the cost of ten acres bought a few years ago, also five million dollars.

We propose that those parks everywhere shall be service parks, distinguished by the baseball field, the tennis court, the playground, the running course-by everything that contributes to the wholesome life and activity, the health, the strength and the recreation facilities which make the community orderly and happy; and thus is the purest and surest economy that any community can undertake creating.

We want these playgrounds to be efficient, we want them provided with teachers of play. It is a fallacy to assume that the child knows how to play. No child ever knew how to play except as the mother first taught it, and associates, also mothertaught, followed with suggestions. Children must be instructed to play. Play is the business of the growing child; it is the work for twelve, fifteen and possibly twenty years of life; and it ought to be ordered work and suggested work, controlled only in the sense that the child is taught how to make itself happy and lovely, and in sympathy with the outdoors, which mean so much to our citizens.

We urge parkways-and the idea becomes plain when a community has engirdled itself with green grass, with open spaces, so that anyone needs to travel but a half mile at most to get right at something municipally owned, and therefore commonly owned, which shall restore the lost energy dissipated in the world's work. Last July it happened that I was in Chicago one hot Sunday, and I wanted to see how Chicago enjoyed herself under such conditions. I found, to my absolute surprise, that, notwithstanding the temperature, which was much in excess of 90 degrees, the great open areas in the parks were most fully occupied by throngs of people. They were sometimes simply sitting on the grass in the sun; more times they were playing ball, or, in one or two places, their own individual national games; but they were all in the open. Of the two or three hundred thousand people of Chicago's teeming millions that day using the parks, I believe fully 75 per 
cent were in the open spaces where the sun beat on them. These people were working people. All the week they had been shut up in workshops, mostly sordid and unpleasant, with nights spent in houses little more than kennels, and when the time came that they could throw off the shackles they wanted the open space, the green grass, the great expanse.

Do not forget it, ladies and gentlemen: The village green for the town, the great, vast open space for the big community. It is as necessary as policemen; it is a great deal cheaper, and to connect these by ribbons of green is certainly the greatest prudence, the greatest economy, the greatest civic wisdom.

Now, all this means one thing: that the modern community desiring beauty, seeking the greatest efficiency, which does not plan for it, is going at the work wrong side to, or upside down, and stupidly. Would this city be to us now a joy if George Washington had not had the imagination to see a century ahead the need for a great federal city? Would Washington be as beautiful if it had grown as have Pittsburg, Philadelphia, New York or Chicago? If Washington had grown adventitiously, it would be as formless as these American cities are now. But the first president had great foresight, and I am going to say that I believe God inspired Washington to lay down the lines of a great federal city. Now, we love our Federal City; we want it made more beautiful; we jealously resist any intrusion upon Washington's plan.

But, please note this city is a joy because it was planned. If the gifted gentleman who presides over this meeting should simply take little tubes and brushes, shut his eyes and smear over some canvas, he would never show us the result, I am sure. Everything he does is the result of a plan. So must our cities be. We must get together and see to it that each community which we wish to be perfected has a definite plan. Is there a new street to be cut? It must be cut on the plan. Is there a park gate to be erected? How does it agree with the plan? When we do that our money will be well spent and we will get complete effectiveness, and not until then.

There is another branch of the work of no less importance. in fact, of more importance to the American Federation of Art. Ladies and gentlemen, of what avail is it to you to see 
that Federal buildings are of good form, that great works of art are bought for the people, if these great works of art are placed in cities the surroundings of which, so far as natural scenery is concerned, are not considered? How much can we do with art in life when we have desecrated scenery in the world? Thus, I say we of the American Civic Association stand for the preservation of natural scenery. This beautiful land about which we sing we ought to keep a little of its beauty. It ought not all to be given up. So the American Civic Association has stood vigorously for the preservation of natural scenery. It was through our suggestion that President Roosevelt declared the Grand Canyon to be a national reserve.

It was through the American Civic Association that Congress passed the Burton Bill, which at least checked the desecration of Niagara Falls, our greatest scenery heritage. That hateful Section 9 of the Sundry Civil Bill has managed to draw the tooth of the Burton Bill's restriction, and to make ineffective the work of our good friend Millet to a certain extent, but I cannot believe that the people will ever cease to demand that Niagara Falls shall exist to create higher ideals in our minds, to increase the pleasure of the whole world, rather than to produce dividends for a selfish few.

We also insist that the Yosemite National Park and all national parks shall belong to us, and that even San Francisco shall not lay her hands on one-half of the Yosemite that may have a dubious water supply. If we are wealthy enough to dig $\$ 200,000,000$ worth of ditch across the continent a thousand or more miles away, surely we are wealthy enough to keep a few of our memorials of national glory, are we not?

We are to have artificial scenery. No man can create natural scenery, but we have been changing it mighty fast. What are the waterways to be like? Has anyone heard that the Panama Canal is to be anything more than a ditch? Go to Sweden, France, Germany, Holland and see what the canals express. Cannot we have beauty considered in this conservation movement?

I think the national authorities are singularly obtuse on this matter as yet, but I am sure that the work that is done here and that is fostered by such an organization as this will tend 


\section{1}

toward the creation of a sentiment which will insist that life shall never be less beautiful in America than it is at the present moment.

In conclusion I want to say that the American Civic Association stands for a better and more beautiful America, because it believes a more beautiful America will be a better America, and because it knows that a better America must be a more beautiful America. (Applause.)

According to the programme Mr. George W. Cable should have been the next speaker, but by mutual consent he exchanged places with Mr. Walter Scott Perry, Director of the Department of Fine and Applied Arts, Pratt Institute, Brooklyn, who was to have spoken later. Mr. Perry was introduced by the Chairman. 
ART EDUCATION IN THE UNITED STATES.

ADDRESS OF

Mr. Walter Scott Perry.

Mr. Chairman, Ladies and Gentlemen: I have been intimately acquainted with art education in the public schools and the training of teachers of drawing, for many years, and I shall hope to speak from experience. I have just come from the meeting of the Western Drawing and Manual Training Association, in St. Louis. It was a great meeting, and one could not be present at that meeting for four or five days without realizing what the special art teachers in the graded schools and the high schools are doing in the training of children. This was shown by a splendid programme and an exhibition of schools from many different cities and towns, an exhibition showing great improvement in quality of work over the exhibitions of a few years ago.

St. Louis opened its doors to the people and the members of the convention. Meetings were held in its many high school buildings, and there was much in those buildings to indicate the hold that drawing and design have upon the community at the present time, in contrast with that of a few years ago. I visited these high school buildings with great interest, and also the Teachers' College for the training of teachers. A thing that interested me very much in connection with the latter was the fact that they have erected in the grounds of that building a large conservatory, with a gardener to give his full time to it; and there are raised the plants that are used by the students in their scientific and art work. (Applause.) They also cultivate about one-eighth of an acre with plants for the same purpose-and I was told that the conservatory and garden were maintained so that the teachers and pupils of other schools could draw upon them for their supplies.

Last Monday I visited Chicago and went the round of some of the public school buildings and playgrounds. It is always with the greatest interest that I visit these. The importance of playgrounds has already been spoken of this morning. I think that in Chicago it was only four or five years ago that 
an appropriation of about ten thousand dollars was given for this purpose, and I am told that the city appropriates now something like a million dollars to carry on this great and growing work. There are now twenty-eight small parks and these parks are laid out in an artistic manner, with beautiful buildings and shrubbery and flowers. There is the ball ground for the boys, the outdoor gymnasium for the boys and one for the girls; the indoor gymnasiums; the swimming tanks outdoors and indoors; the wading pools for the children and the sand enclosures for the little ones, with comfortable seats for the mothers to gather and watch their children while they play.

To me it is tremendously impressive to visit one of these places and realize what it means for the future. A's I stated, the one small playground of a few years ago has already grown to twenty-eight and their tremendous influence for good cannot be measured. "The entire object of true education is to make people not only do the right things, but enjoy the right things." (Applause.)

By locating these parks about the great city they have taken from the streets that energy which was oftentimes used in a most mischievous and even criminal way. The boys are now not only enjoying themselves, but they are being trained in the laws of health, good behavior and good citizenship. They are taught how to play their games in the best way, and kindergartners in summer supervise the play of the young children and assist the mothers in giving to them proper care.

All this is in the line of art education, for I believe it is in the training of the children and the people to appreciate the best that we are to accomplish much in art, It has been well said many times that it is far more important to train a hundred persons to appreciate art than to train one artist. Otherwise the artist has little chance, and it is by putting the best into the life of this great body of children who are to become the men and women of the future that we are to exert the great influence for art and beauty.

I am asked to speak upon the subject of "Art Education in the Public Schools." How was it introduced into the public schools? It is not very many years ago that drawing was first 
introduced into the Massachusetts schools and made compulsory, the first among the states, and the argument used at the time for its introduction was simply this: "We would introduce drawing into the public schools and train the children to make designs that we may not have to import designers from abroad." That was the argument made over and over again. Then there were those who said, "We must introduce drawing into the public schools, because of our great industries-to teach the children to make and to read working drawings." Then came the subject of drawing the appearance of objects. All these new things were fought against bitterly by members of school boards and by others; but it has come about now that drawing in the public schools must be taught everywhere and the subject is based upon three great divisions, in order to teach all classes in all walks of life, the fundamentals of art, and these three classes may be named in various terms. Sometimes we say "Facts of Form," which includes working drawings, because such are the basis of our industrial industries. Then there is the subject of "Appearance of Form," that is, the representation of objects as they appear. The other division is "Decoration of Form." These three divisions which may also be called "Constructive Drawing," "Perspective Drawing" and "Decorative Drawing," are the three fundamental divisions, and all our work in drawing must come under one of the three. Any system of drawing that does not recognize the three is not recognizing the three great divisions upon which all art work depends, and which must be recognized in order to meet the conditions of the constructive industries into which many of the children go, and of art education pure and simple.

Manual training has come to unite itself with art, and that means a great deal. Dr. C. M. Woodward at the meeting last week in St. Louis was one of the happiest men there. He, with his friends, did much to make the meeting a great success. You all know what Dr. Woodward has done for Manual Training. His was the first real manual training school in this country, and now we have manual training or applied art schools throughout the country. I well remember when Dr. Woodward made his first address before the meeting of the 
National Education Association at Saratoga, when there were probably several thousand people in that city who came to attend the general meetings. But there were just fourteen people in that audience-all the rest of that great convention cared nothing for the subject at the time. The next year Dr. Woodward invited a person from abroad to speak on the subject. When the time came he said, "Dr. Woodward, I do not think I ought to go on for I observe that there is evidently little interest as there are only seventeen or eighteen people in this audience." Dr. Woodward said, "Go on, I had only thirteen or fourteen last year, and now you have seventeen or eighteen this year. There is no telling what influence we may have if we keep right at our work." I can remember the time in a community in which there is now a manual training school with over two thousand students in the school, that the school board ridiculed men who offered money to further manual training, saying it was of no value.

When manual training was first introduced it was introduced as mechanical training, but there has now come about the applied arts work in these high schools. At first it was all mechanical training, but now there has been dovetailed into every part of the regular course the drawing and designing of objects and the applying of art to the work done in the shops.

You visit such schols as those of St. Louis-I refer to the high schools of St. Louis because of the recent meeting-and there you find work done in the name of the applied arts in leather and other materials that seems almost incredible for students of the high school age because of the beautiful results in design and workmanship. And I would say to anybody who is inclined to criticise the arts and crafts in a wholesale way, as has been done in discussion in this convention, go to some of these places where they are doing truly artistic work, and see what remarkable work is being done by the pupils. You may find it in many other great cities-Indianapolis, Cleveland, New York, and Minneapolis and other cities.

There has come to be a demand for trained art supervisors that was not known a few years ago. The time was when almost anybody could get a position as a teacher in drawing, but it is not so now. The school boards and superintendents of the 
country are requiring thoroughly trained art teachers. Permit me to make one personal allusion in regard to training classes for teachers in an institution with which I am connected. The people who come to that training class are largely those who have had much experience in teaching or art study, many of them having had three, four, five or six years previous training in art schools, some having had college training. It shows that they realize what thorough training means. And so there is going out into the field all through the country these teachers of drawing who are carrying with them a great influence in the directions that have been indicated by the speakers who have preceded me.

Now there comes the thought about vocational schools. That is a litle bit outside of my province, but I would like to say this regarding the movement for vocational schools. I heard a person make an address only a few days ago, who spoke as though in order to give the vocational schools a chance we had got to sweep away what we have, and he criticised the manual training high schools, and yet he said there are only four trades that we teach in these vocational schools: wood working, pattern making, plumbing and machine work. But I claim that the vocational schools are simply going to give another class of students a chance. Manual Training high schools have given a class of students an opportunity that we could not give them a few years ago. We have opened the doors to a larger number of boys and girls to pursue the higher studies and now that general manual training work is connected with the applied arts, we are turning out students who are going to be a great influence in the future in the application of art to industry. We are holding them in school for a longer period of time than formerly. But we have not been able to hold many of the boys of fourteen years of age and upwards. Vocational schools, then, are for the purpose of giving another class of boys a chance they have not had. The vocational schools will not hurt the manual training schools, but will simply supplement and support them.

I heard a person who has charge of the vocational work in one of our states say a few days ago, "I used to think manual training was mechanical training. I have got away from 
that now. I realize fully that the manual training of the future in these schools is the applied arts training, but my department is the vocational schools, and I feel that the vocational schools will simply make the demand for manual training or applied art schools the greater. We shall simply put into the different cities those trade schools that are necessary to hold and to train those boys that we cannot now hold in the high schools and the boys that we ought to help by giving to them a trade."

Speaking rapidly and covering hastily the work of the public schools, I want still to say a word about the art schools. There has been, I believe, a great mistake in many of the art schools in the past in the nature of the training; it has been what is called academic training. There have been, unfortunately, too many artists who have felt that the character of the training for the student was a certain amount of cast drawing, a year or two years; and then a certain amount of life drawing. The student is not interested in anything of a real art nature when he is simply drawing from casts. $\mathrm{He}$ is simply training his eye to see and observe, and he is training his hand to execute. But there is the opportunity for a great deal more real art training. There is no reason why a student should draw from the cast or from life all day, or through the week. The eye tires after some three hours work, and the work in the art school in the afternoon should be supplementary to that of the morning, and every student should be compelled to do applied arts work. If he gives his time mornings to the life drawing, etc., he should give his afternoons to composition and to various forms of applied art work, for it is the applied arts work which is going to mean a great deal in the future, to the individual student and to the public.

Walter Crane has well said: "The true root and basis of all art lies in the handicrafts. If art is not recognized in the humblest object and material, and felt to be as valuable in its own way as the more highly rewarded pictorial skill, the arts cannot be in a sound condition."

There has been a great transformation in most of the art schools of the country in bringing some of these things into the schools and compelling the student to do something more than to draw from the cast and from the life. He is made to 
take up composition and design seriously and to think of these things in parallel courses from the time he enters the school. And the student soon becomes intensely interested in the work.

To be sure, a great deal has been done in the name of the arts and crafts in an amateurish way that is not to be encouraged, and I would be the last one to encourage it, but it simply illustrates that all things in their beginning may have weaknesses but if rightly directed will become strong. People rush into a new thing, but in the end the pendulum will swing the right way. A few years ago in Pratt Institute we had a room equipped in June as a jeweler's shop would be equipped, and we employed one of the best men from one of the leading houses in New York. We were to open a course in jewelry where the work was to be of a skilled character as well as an artistic character. In September there was one applicant, and that was about all we expected. We wanted to begin the right way and demand the right kind of work. Today we employ as the teacher of the class in jewelry a man who had twelve years' experience as a jeweler; who in 1890 went to Europe and studied as a sculptor two or three years, came back here and practiced his art work together with his other work; was the sculptor of one of the figures on the triumphal bridge at Buffalo, had one of the figures of the colonnade of states at St. Louis, one of the six figures on the permanent Fine Arts Building in St. Louis and has done much other work as a sculptor and designer. I only mention this to show that we put into that work the artist and the skilled workman. What is the result? This year we must enlarge that department twice over to give the students who wish the opportunity to work in silver and gold and to express their art thought in making rings, pendants, and bracelets and all forms of decorative ornaments that we are accustomed to use in our homes and upon our persons that are made in precious metals. The young men are taken, after three years' training, into the best houses in New York at good wages, and the young women have been most successful in their own studios in filling orders for the things I have mentioned. Some of these young women tell me they are earning a fine income in a constantly growing practice, good work bringing more of the kind from an ever- 
widening circle of patrons. So I say that it is in the arts and crafts work that the art student can do much for himself and for the art of the country. I mean arts and crafts work of a serious nature-that which calls for skill, for splendid design and splendid execution.

I have suggested that there is a tremendous change that has come about in the name of Art Education throughout the country. Some of you may have been present so long ago as 1884 at an exhibition of school work in Madison, Wisconsin, when the National Educational Association met there, and 10,000 visitors were in that city. At that time one of the largest school exhibits ever held in the country was held in the new Capitol Building, but what was that work compared with the great exhibition in Chicago in 1888, what was that compared with the later exhibitions, and what were these compared with St. Louis, in 1894, when in the Fine Arts Building, where pictures were hung upon the walls, we had most beautiful arts and crafts work occupying cases in the same rooms and placed there upon the same art basis as the other workrecognized as of as real art value as the pictures hanging upon the walls.

Only a few words more and I will finish.

I have been greatly impressed with the work of this meeting. I met here with the small committee in January to make arrangements for the meeting. There were only eight or nine present on that afternoon. The time was short to prepare for this first meeting, which has proven of greatest interest and profit. Delegates have come from many places. Papers have been presented upon many great subjects which concern us as citizens, in the laying out of parks, in the beautifying of cities, and in art education in general. But there is one thing more that I think has not been touched upon that I believe can result in great help to the people and can be carried out by this Federation. We have these exhibitions, of which I have spoken, in the great cities, but the smaller cities and towns are saying, "What can be done to bring exhibitions to us?" The art teacher is saying, "What can be done to help me as a teacher of drawing to educate my community? Can you send me an exhibition?" That is the request that is coming from 
all over these United States. I have had many requests of this kind this year. Exhibitions are asked for down in Texas and in the far West, in fact in all parts of the country, and I believe this association can do a great deal in helping to establish traveling exhibitions. These exhibits can be contributed by different schools of the country. The work can be submitted to a jury-an exhibition that would fill one or two rooms can be carefully and beautifully mounted, for there is much in the mounting. In sending out an exhibition we should show artistic mounting and how all things should harmonize in color and the whole present a beautiful unity. If we had a certain number of school exhibitions of this kind ready we could send them to hundreds of towns and cities in this country this next year, and the demands would come in so rapdily that we would not know how to supply them. I do not know how many times I was asked at this western meeting, "What can you do to help me in my little town, or my little city, in supplying an exhibition or exhibitions for the people?"

This subject, I think, has been mentioned in a general way, but has not been discussed, and therefore I leave it as my final word in this rapid review of what has been accomplished in the name of Art education in the public schools in the last few years in the United States. (Applause.)

The Chairman. Ladies and gentlemen, it is unfortunate for us that Mr. Perry has to go away this afternoon, for he has been obliged on that account to cut short his very interesting address, and his remarks, to my mind, stimulate discussion very largely-not criticism, but discussion. If he were to be here longer, say another half day or so, I think it would be very enlightening indeed to discuss the subjects which he talked upon. Personally, I am greatly wanting a motion to put in the list of committees, a committee on circulating peripatetic exhibitions, which we really intended to be in it when we put in museums and collections of art, under which this committee could work. Provisions for these circulating exhibitions would be a very important thing for us to undertake.

Now, I believe that closes the exercises of this morning, and in accordance with the programme this meeting will now ad- 
journ, unless there is objection, until 2 o'clock this afternoon, when $\mathrm{Mr}$. Cable will have had his luncheon and be ready to give his paper.

Mr. James B. Townsend. Traveling exhibitions are something very near my heart. The trouble that I encounter as regards these traveling exhibitions is not that the exhibitions cannot be pretty easily formed and sent out. It is the commercial troubles. Towns and cities and art societies in small centers have not the money to pay for insurance and transportation, to say nothing of boxing, unboxing, etc. I had the pleasure of sending an exhibition to 125 selected American cities-to all the southern cities-two years ago, visiting Nashville, Atlanta and even Tampa, Florida, which was then the farthest point south reached; also Jacksonville, Savannah, Charleston, and so on-Lynchburg and Baltimore; and despite all these difficulties, and despite a fund was asked from each art society in those cities, the venture proved a loss of some $\$ 2,000$ or $\$ 3$,000 for the reason that the railroads of the south in every case charged more than schedules called for, or that they agreed to charge; and the expenses, of boxing, of hanging, of taking down, of packing and shipping back were thirty, forty or fifty per cent more in almost every case. Mr. Woodward is from New Orleans, and he knows something of that diffculty. It is a commercial difficulty, gentlemen. If this association can raise the funds to provide for traveling exhibitions nothing could educate the country more easily or in any better way. The trouble is a commercial trouble; and the small communities all the more cannot pay, or are not willing to pay, the expenses necessary to bring these exhibitions to their cities and to pay the cost of the transportation, packing, unpacking and insurance.

It is something I believe this association could take up and which it might accomplish by raising a fund for this purpose.

The second exhibition was by the American Water Color Society. The body of painters known as "The Ten," in New York, sent their pictures to a certain number of the larger cities-to the New York IMuseum and the museums of Pennsylvania, and to the smaller cities, New Orleans, Tampa, Jacksonville and Savannah, which have not anything except small 
art organizations, which have not the money to pay the necessary expenses. Of course, you can get back some of the cost by charging admission fees, but you have got to have a fund to start with.

Mr. Perry. Mr. Townsend has spoken of one of the difficulties of picture exhibitions. I believe in getting in an entering wedge; and if you cannot get pictures into some of these places you can get an exhibition of work mounted on card boards that does not cost as much as an exhibition of framed pictures does. Moreover, it is not the larger cities, the cities with museums that are making these requests. It is the smaller places and the places which could not possibly at present have these larger exhibitions. If you get the more elementary exhibitions started something that can easily be provided, though not a thing is framed but beautifully mounted, it will attract a great deal of attention, and I know from experience that hundreds and thousands will come to such exhibitions. These things can be done, and when you get the community educated the money will come.

I had the privilege quite a number of years ago of speaking on the subject of pictures for school rooms. There were not then the pictures in the school buildings that we find now. I was surprised to find so many interested people at the meeting on that cold morning. I tried to tell them where they could get material, how it could be shown, etc. And they said, "That is easy, now that we know how to do it. We will raise the money." They started right there, and four weeks afterwards they wrote me they had raised twenty-five hundred dollars to start the work in that city, and now its school buildings are filled with pictures. People want to know how to do these things, and we must put things before them that they can appreciate and the work will grow rapidly.

Mr. WOODWARd. Have we a committee to which these matters can be referred, or is it possible to appoint such a committee?

The Chairman. We have a very comprehensive abbreviation- "etc." at the end of the list of committees.

Mr. WOODWARD. That will cover it.

The Chairman. I think that will cover it. 
Mr. WoOdWard. Time is too pressing to take up so important a matter.

The Chairman. I think the officers will see that there is a Committee on Exhibitions.

Mr. WOODWARD. I merely want to say that I have the honor to be the President of the Louisiana Art Teachers Association. We have an exhibition on the road right now in the State of Louisiana, and the towns pay for it on request.

The Chairman. If there are no further remarks the meeting will adjourn until 2 o'clock. I hope everybody will come back this afternoon, because we shall have a very able paper from Mr. Cable. We will meet in this room (Red Room).

Thereupon, at 12.40 P. M., the meeting adjourned. 


\section{SIXTH SESSION.}

Thursday Afternoon, May 13, 1909.

The meeting was called to order at 2.15 o'clock, Mr. Frank D. Millet (Secretary) in the Chair.

The Chairman. Ladies and Gentlemen, I take great pleasure in introducing to you Mr. George W. Cable, who is known to us all by his writings and to many of us, with great satisfaction, personally. (Applause.)

\section{THE NORTHAMPTON PRIZE FLOWER GARDEN COMPETITION.}

ADDRESS OF

Mr. George W. Cable.

Mr. Chairman, Ladies and Gentlemen: I have promised myself all the way here and every hour since I have been here that when at last I should stand up to speak to you I would imagine you, and ask you to imagine me, as meeting in one of the halls, or corridors, of this hotel, casually, and I simply answering your questions of curiosity or of interest.

I am down on the programme to talk about the garden prize competition of Northampton. Twenty-two years ago we founded in Northampton the Home-Culture Clubs, without the least idea that they would ever grow to exceptional proportions. The demand must have been much better than the supply, for it was on the demand for the thing and not upon the supply or support that it grew. It grew and took on from time to time various additional functions, finally dropping the function with which it began, and gradually assumed the aspect and quality of a People's Institute, and although I use so large a word, I think that the growth of the institution has earned the title, and I should not wonder if we find it essential or valuable to the interest of the Home-Culture Clubs to change their name, and call them plainly, "The People's Institute of Northampton." 
Our business was, as the name indicates, the culture of the home, not merely the culture of individuals at home, but the recognition of a truth which for years we have carried as a maxim on the title page of our Year Book: "The Private Home is the Public Hope."

Now our work is very much indoors. It is founded on the idea that spiritual gifts can always be exchanged, can be lavishly bestowed, without ever pauperizing anybody. It is not the reception of spiritual gifts that tends to promote idleness or dependence. It tends to promote industry and independence. So it has worked out, and in those twenty-two years we have never had brought against us, except in the idlest social gossip, which was at once dropped upon our being comprehended, the charge that we were doing anything whatever to reduce the energies of self-help, much less of selfculture, in the people.

By and by, after many years and after a good deal of flattering success, we came to recognize the fact that the clubs were working only indoors and could just as well work out of doors also. The approach to the home is from out-of-doors. That is a very simple truism that nobody will deny. The approach to the home is from out of doors; the approach to the home is through out-of-door contacts.

We found, the moment we had begun this flower garden competition, that we had found the way to the home and made it very simple and practicable. The flower garden competition was conceived upon the suggestion from the Dunfermline Flower Garden Competition in Scotland. Dunfermline was the first capital of Scotland, as most of us know, and the flower garden competition was there because Mr. Carnegie gladly consented to furnish the prizes for a flower garden competition. I was talking with him one day at his own home in Scotland, as we were driving together, starting off to fish, and I caught the first fish. That is to say Mr. Carnegie mentioned the flower garden competition of Dunfermline, and I said, "That is home culture if anything in the world is home culture-if there is any vestige left in the American mind of a sentiment that the boundary of the home is the fence and not the window." $\mathrm{Mr}$. Carnegie said that he would be glad to accede to my request 
to have his secretary furnish me with a copy of the rules and scheme of management of that competition, and he would furnish the prizes. Well, since that day the work has grown so that Mr. Carnegie's annual check for a few scores of dollars furnishes only about one-third of the prizes we bestow. To begin at the latter end-last year we had in this competition almost five hundred gardens of the little city of Northampton, which numbers about 20,000 people. This year our work is in the hands of such efficient secretaries, backed up by the enthusiasm of certain ladies of the town, that from a memorandum given me at the last moment before leaving-given by the Secretary of the Home-Culture Clubs-the most moderate estimate that we can make of the number of gardens we shall count in this year's competition is eight hundred and thirty.

The competition is ten years old. We have patiently waited for its growth, to be natural, I will not say, but to be at any rate normal. We have pursued and do still pursue a diligent solicitation, and without this diligent solicitation I think the result would still be comparatively small.

Now notice, if you please, that these eight hundred and thirty gardens will stand for eight hundred and thirty homes. Down South we count five persons to the home; whether that is too much to count in New England is a question, but there are enough Poles, Slavs, Italians, Sicilians and others of the laboring class to make me assume that it is a moderate estimate of the average number in a household. If that be so, then we see that these eight hundred and thirty homes stand for nearly one in five of the entire population of Northampton. So you see the work is pretty well spread over the town.

I am going to get rid of one sad statement now, so as not to burden my mind with it, and not to dash anything I may say hereafter. It has a very bright side to it, which you will enjoy more than a Northamptonian can, and that is the fact which has to be admitted, that at the present time, after ten years of this flower garden competition and annual bestowal of prizes, the workingman, the manual laborer of Northampton, by all odds, is the better gardener rather than the householder who is more well-to-do. I could take you down one, two, three or four of the principal streets of Northampton 
and you would say to me, "Where are your flower garden prize takers? Where is all this change the people themselves talk about?" And when a priest writes to you that "You have changed the entire aspect of my parish," where is that parish and where is its changed aspect? Well, I am glad to say there are no slums in Northampton, and you must not look for those or for any particular isolated quarter that is going to show all this change. This change is scattered throughout the town, and it belongs mainly to the homes of the humbler cottagers. Here and there we can point you out a few prize takers in what we have distinguished as the "Unlimited Competition," and I will proceed to explain that as briefly as possible. The competition has for one of its first rules that the gardens shall in all cases be kept entirely without hired help. But that, you see, would force the whole competition either into the hands of working cottagers, while without that limitation we should force it out of their hands by the handicap of an ability which they can not enjoy, to employ hired help. So in a public spirit and competing for two entirely separate prizes, of an honorary character, and very small in cash amount, the well-to-do people of the town have joined in the competition. They compete with one another. They enter a class called, as I say, the "Unlimited Class"unlimited in that case not being the honorary distinction, but the less honorable distinction-limited meaning, limited to the householder's own labors or such as his neighbors may choose to bestow without charge-gardens that are totally a home product, the product of the householder and any friend that may choose to lend a hand. The first prize was taken by two ladies who had very long been grayhaired and who turned every sod, turned every spadeful of earth in that garden, and mowed every square yard of that lawn with their own hands. The prize the second year was taken by a woman who had to protect every bit of her cultivation with poultry wire to keep the neighbor's hens and chickens out, trespassers that ought to have been kept in the poultry wire.

Now, I want to see how I can make this brief and impromptu account of this work of such suggestive character as to justify being imitated and to stimulate imitation. I want 
to ask myself, first of all, "How would you do this same thing if you had not any such thing in hand? How would you be a leading and guiding and not a misleading and misguiding example?" How do we do it? Well, I wish I could answer that the well-to-do people of the town have the thing entirely in their hands, and that as an organization purposely projected for this particular purpose they raise the money and do all the work of soliciting, and of later visiting for commendation for inspection and visiting for judgment. I cannot say that at all. That is not the way we do it. That may suggest itself to your mind as a practicable way, and I hope it is, but it may be because of our other facilities, because we have not been by necessity thrown upon that resource for our only reliance that we have not succeeded better in that direction. Nevertheless, it remains to be said that in a body of women in Northampton an auxiliary of our Home-Culture Clubs work, as a whole, and especially of our household art school, a considerable number of their members have taken up this matter of the flower garden competition. They make their visits of sympathy, express their admiration and come back quietly and to the Secretaries of the HomeCulture Clubs report what they would have expressed in criticism if it had been their business to criticise on the spot. But the main part of the work is done by the Secretaries, the General Secretary and the Secretary of the women's work of the Home-Culture Clubs. They begin the work by starting on their rounds as early in the spring as the first thawing of the ground suggests the possibilities of gardening. If they should start earlier than that they would find the proposition regarded in the minds of those to whom it is brought, as simply an inconceivable thing. You cannot talk, if our experience is in the nature of final proof, successfully to people about gardening while the ground is frozen. It ought not to be so; and we hope to see the day when we shall be able to send word here by some delegate, that we have got them at last to consider their gardens so early under the stimulation of all the advice we can offer them in frozen and snow-deep weather, that they can begin to garden as soon as the frost is out of the ground. 
However, these Secretaries go and visit the gardens. Last year the two Secretaries, between them, made 1,200 visits. This year I think it will be absolutely necessary that they pay not less than two thousand.

We have the town divided into districts, and these volunteer visitors behind the Secretaries come in turn and visit as many gardens as we can get visitors for. We hoped once that they would undertake to mark the comparative merits of the various gardens on a numerical scale, but we have found so few people who think they know how to garden at all, and such a small fraction of those who think they know how, who really do know (Laughter), that it was impossible to persuade more than here one and there another to mark on a sliding scale the comparative merits of the gardens. So that has to be done finally by the chief Secretary of the Home-Culture Clubs.

If you have no such institution as that to take this up as a branch of its work, then, of necessity, you must have your inspection done in some way of your own devising; but I do not see why that should be an insuperable difficulty in the way of any desire to project such a work.

We make our prizes both large and small. Certain friends suggested that we should offer only small prizes and spread them among a great number. Well, we did that, but we did not stop there. Or we stopped there, but did not begin there. We established in the first place one or two large prizes, if you would call $\$ 15$ a large prize. Fifteen dollars is the first prize, ten dollars is the second prize, and then the awards run down a scale diminishing by half-dollars to $\$ 2.50$. The judges reserved the task of judging only a limited number of all the gardens in competition, for where could you get three valuable men or women to undertake to see eight or nine hundred gardens in a short period of time? A great number of which of course, being known already to be distanced in the contest.

We began by offering this list of prizes to all the competitors in town in a lump. I think our very first rule-it has been a long time since we have looked at the rules; they are more of a tradition, except where some of them have fallen entirely into disuse and neglect-was that no person professionally engaged in gardening should enter the competition. I have 
within a few months seen a brave scheme for flower garden competition throttled in the outset by putting it under the control of uncultured nurserymen. We keep every aspect of commercialism or commercial influence out of the thing. No professional can touch it on the inside.

When we offered our prizes the first evidence of necessity for a new rule was the fact that flower gardening, being so contagious, developed in nuclei, here and there and yonder, and we were getting what artists like these behind me abhora spotted effect. (Laughter.) So we promptly divided the town into districts. That made it more convenient for the flower-garden visitors. Also it made it easier for us to get flower-garden visitors, for visitors would say we will undertake a certain part of a district; but the main advantage was that having divided the town into districts we divided the prizes into five groups, and each of those districts was entitled to three prizes-no district could take more, no district could take less. In that way we were sure that the gardening would not run into rings and spots in the town. Thus the gardening has been spread all over the town; and it soon became manifest to the competitors throughout the town that what we were driving at was not the encouraging and rewarding of the very highest art in gardening, but the beautification of the town of Northampton, and the spread of home gardening for the home's sake throughout the entire town. So it has worked, especially in those elements of the town where it was most essential it should work.

Then we had to lay on another limitation, and we decreed that the garden or garden district which took the capital prize could not take the second prize. It might work a certain arbitrary injustice to the second best garden in the town of Northampton, but it promoted gardening! It promoted the refinement of the home dooryard throughout the little city. If No. 1 took the capital prize, District No. 2, 3, 4 or 5 must take the next prize. The third prize could go back to District No. 1, because the district that would win the capital prize was very apt to have much of the best gardening in it and to furnish the successful competitor for the next prize that it could be allowed to take. If it took the third prize, 
then it could not take the fourth; and if District No. 3 or No. 2 took the second prize it could not take the third. You see how it worked. No two consecutive prizes could fall to the same district.

The result has been such a growth in the competition that we have had to increase the number of districts, and this year shall have to increase it again-I mean by subdivision.

We had great apprehension that this volunteer visting, or even the Secretaries' official visiting, would be resented by these homes, and it is a very happy thing to be able to say that in these ten years there has not been a note of resentment from those competitors, hundreds upon hundreds and now aggregating thousands if we count them over again from year to year-thousands, anyhow, if we simply count the number of gardens that have entered the competition from time to time, have seen us come and go, have welcomed us with alacrity, and have accepted eagerly, cordially, gratefully our criticisms as well as our praises.

Moreover, they conform.

They are as splendid a body of conformists as I ever saw. They conform to the criticisms and counsel of us who go around and tell them where they are gardening wrong and where they are right, and they find that by conforming to those counsels they win the prizes. I have myself visited hundreds of them in a single season, and as I go from garden to garden, my one word is, "I am taking as good care of your garden and of you as if you were the only person that I had chosen of my own preference to take the capital prize." But I do the same thing to the next person I come to, and another part of my declaration to each particular competitor is: "You are only getting the same treatment that everybody gets." My endeavor is to make everybody take the prize. (Laughter.) But they have learned now that they cannot enter the competition raw and take the prize the first year; there is not a ghost of a chance left. Of course, there was at first. They enter the competition now knowing that in the course of two or three years they can hope to begin taking prizes at the bottom of the scale and climb up. An interesting psychological fact is that some can begin at the bottom and climb out 
at the top and some can climb just so far and can never get any farther; and so they go. Mrs. Johanna O'Brien began at the bottom of the scale and was so well satisfied to climb the ladder rung by rung that when she got out at the top she had taken nearly $\$ 50$ worth of prizes.

I think I had not better be too free with names, but will mention another person, and call her Mrs. Anonyma. She rose with splendid rapidity - she and her husband. I use the feminine pronoun because I am most apt to find the housewife at home, the husband being very apt, in the hours of sunlight, to be off at his work; but very often I find Mr. and Mrs. Anonyma together working in the garden, or else, as the sun goes down and they have had their early evening repast, sitting on a church pew which they had somehow or other captured and put into the garden in a very advantageous and artistically correct position-sitting there and sunning themselves after sundown in the smile and approval of the passing multitude. (Laughter.) Mrs. Anonyma once said to me, "Everybody stops to see me garden; everybody stops to see it, and one neighbor stops, and he leans over the fence and he says, "Mrs. Anonyma, your garden looks just like a public park." Well, that was because it didn't look a bit like a public park (Laughter), but was conformed to the same great fundamental principles of art which should rule the public park and differentiate the home garden from it. She said, "I didn't have no notion that I would take a prize, but I took the prize, and, begosh! it just covers me doctor's bill." (Laughter.)

Yes, by having the subdivision into districts and the apportionment of prizes rigorously kept in conformity to that subdivision, the district of the poorest taste in the town, the district of the poorest opportunities, has an equal chance of getting as high prizes as it can possibly be expected to earn. Nevertheless, today, as I said before, the average well-to-do gardener in Northampton is, I might almost say, hopelessly distanced in the art of home gardening; and high prizes have honestly gone, for years, to the poorest cottagers. Bear in mind, ladies and gentlemen, that I am so busy trying to get through, in order that I may not be too long before you, that I know not how the time is passing, nor do I know what I am 
leaving unsaid, and I have been trusting from the beginning that you would ask me questions suitable to the order of the house-that you would interrupt me with questions rather than wait for me to finish. What am I leaving out of this thing that makes it inorganic or chaotic? What question is in your mind now that will start me right again?

Mr. PARKer. What is your standard of judgment between the gardens - the color arrangement or the amount of product of the garden?

Mr. CABLE. Not the second.

Mr. PARKer. The color arrangement or the produce of the certain man or woman, or the choicer varieties of flowers, and so on?

Mr. CABLE. First, lay-out. The lay-out of the garden is its anatomy, and the anatomy not being right you could not even make a pretty woman. The second is harmonies: harmonies of form, harmonies of color, all the artistic harmonies, all the careful observance of every rule of perspective, when you give perspective all the significances of meaning you can. A third condition is order-general up-keep; and that leads me to say that our flower garden competition is the most successful clean back-yard movement I know of (Laughter and applause), for the reason that we promptly made the rule that the garden was not something in the yard, not something behind the house or before the house, but it was the whole place-house, dooryard, hen yard, barn and everything whatever within the bounds of the lot, including especially the bounds themselves. (Applause.) The result is that the first thing you get is a clean back-yard. When we began they used to take us struggling through a lot of rubbish, and then through a lot of high grass, and then come by and by upon a spot that was revealed at last, and say, "There is the garden." (Laughter.) Our answer was cruel, "We beg to differ. Your whole place-of course, not a farm, but your whole dooryard, from house to the bounds and from bounds back to house, front and rear-that is your garden. You cannot come into this competition with anything else, and that is enough." 
We found that the stimulation of window-gardening was not only idle but useless and misleading. I have never yet in my experience found any one who wanted to window-garden when they had a chance to garden on the ground, and who would do anything that was really worth while.

Now, I am coming to points that I want to make with a great deal of confidence that I am right, and a frank confession that $I$ have not proved it by actual experiment. I am, of course, in receipt of a very considerable correspondence, and very constant also, asking for particulars, and almost invariably beginning with the statement: "We have begun already, and we have distributed (so many) thousands of packages of seeds to the children." We have never given a package of seed to a child in the ten years history of this movement. We have the children in sight, but in our garden competition children are seen, not heard. In our competition we assume that if the parents take an interest in gardening the children will; they will take an interest in gardening, not merely in raising flowers; and if we begin with interesting the children we have got the whole business of interesting the parents to do afterwards. Moreover, if we are going to have a genuine competition of gardens, children have not reached that age when they are competent to lay down an architectural plan in a garden or anywhere else. They cannot give themselves successfully to garden architecture and our notion is that good gardening begins with the architectural plan of it. Now, the children do take an interest. Everywhere we see the children seconding their parents' efforts, they are working and they are learning, and the result is we have not merely gardenbeds of flowers. We have properly laid out gardens.

I said before that this competition actually takes in, as you see by the numbers, about one-fifth of all the homes of Northampton, but it takes in a great deal more than that by indirection. You will see what I mean when I simply give you this little anecdote of a woman, to whom I said: "Who told you to lay out this garden? You are in the garden competition, but I do not see your name on the list."

"No, I am not in the competition." 
"Why are you not in the competition? It costs you nothing. What do you mean by being out of it?"

"Well, we do not feel like going in."

"Who taught you to garden this way?"

"Nobody taught us to garden this way, but lately we have noticed that this is the way they are gardening." (Laughter.)

So we see everywhere gardens that give some illustration of that old tendency born with Adam (who was not born at all), born of a notion that if somebody is on one side of a movement this other somebody must range himself on the other side. People of this tendency stay out of the competition and imitate it on the sly. (Laughter.)

We had for one of our first requirements a multiplicity of flowers, and saw instantly, almost, that that was misleading. We found that as far as some persons had any notion of flowergardening at all it was simply the rearing of flowers. The thing to do was to pull them away by the collar, if they were men, and in a proper way if they were women-to pull them away from the notions of beds of annual flowers, and to persuade them to buy shrubs. I do assure you that when we began to talk about shrubs we found we had to say bushes. So many did not know what "shrub" meant; they thought it was something to drink. (Laughter.) You cannot be too particular (Laughter) about how you talk to people who are not used to your own words, you know. (Laughter.)

I said on one occasion, addressing them, "Now, of course, much that I say may be altogether trite to you." After the meeting a young man lingered and went up to Miss Someone, the Secretary, and said: "Miss Someone, what did Mr. Cable mean by "trite"? Miss Someone's curiosity was aroused, and when she came to sound him a little she found he thought it was something to eat (Laughter)-something you buy at the butcher's. (Laughter.)

So for years we have been selling the competitors shrubs, until it has become a definite part of the movement, and we sell those shrubs to them now by thousands. Well, if we can buy them on the hundred rate we can get them for a mere fraction of what they have to pay at the rate of single plants. We have warned them and warned them, and shall forever warn 
them against the wandering nursery agent. (Laughter.) One poor woman-she belonged to a very frugal race, and she wanted a prize very badly, and our Secretary said, "Why don't you buy shrubs? You can never take the prize any more unless you learn to plant with shrubs, so that your garden will last from the 1st of May to the 1st of December, instead of from the 1st of June to the 1st of October. You can never take the prize unless you buy shrubs." She said, "I bought a shrub this year," and she pointed to a hydrangea paniculata grandiflora, which they call a "high gerangea" to distinguish them from the geraniums, which they call "low gerangeas"- she pointed out the "high gerangea" and said she had bought that.

"How much did you pay for it?"

"Seventy-five cents."

"I am sorry you did not come to the Home-Culture Clubs garden for it, because you could have gotten ten of them for that price."

This reminds me to say that a part of our scheme is that we have turned the Home-Culture Clubs grounds to account. If you have not the Home-Culture Clubs in your little town or city, you can probably find some other ground available for the same purpose. We have not turned ours into a park, for it is only three acres, but this year these three acres begin to show fine progress as a model home garden. There is our model for all our hundreds upon hundreds of workingmen's and other men's home gardens. We are gardening correctly, and to garden correctly we began by getting a professional garden-architect's plan.

Well, I would like to answer another question.

Mr. Eli Harvey. May I ask one?

Mr. Cable. Certainly.

MR. HARvey. As you go around in your "good shepherd of the flock" visits, do you advise all those people with back yards to lay them out at first on a geometrical plan or do you allow them to intersperse the roses with onions and such things?

Mr. CABLE. It may be a narrowness on our part, but the competitor who lays out a geometrical plan in his little door- 
yard is doomed. (Laughter.) He never gets in sight of a prize.

Mr. Harvey. You encourage, then, naturalistic gardening?

Mr. Cable. Yes. I was going to say, "Yes, of course," but that might offend somebody, and I will wait until I see you alone. Just what I will say when I see you alone I need not to say here. Natural gardening, gardening along the lines of nature, is what we inculcate on the principle that if we are going to put Nature into subjugation we should put Nature only into as much subjugation as is essential to the greatest beauty which the utilities of the home will allow.

Miss Martha Brookes Brown. What suggestions are given these people for the things they should plant? Are they left entirely to their own choice and copying one another, or do you have lists and definite schemes made, that is, schemes that they could follow, as would be an A B C scheme, or are they left absolutely to their own choice in evolving a scheme as slowly as they may?

Mr. CABLE. I fear that I shall incur the opinion of the meeting that I am an idle and shiftless man when I tell you that if anyone dares in my presence, during one of my visits, to intimate that he, or she, wants to lay out the garden, I stop right there and lay it out for him or her.

Do we suggest that they plant certain things? They found us out early - they found that we could suggest, and we found on our part that a great reason why there is so little shrubbery planting is because people do not know what shrubs to ask for, and often would not know the habits of the shrubs, if they did know their names; and we not only suggest shrubs, but we have issued a catalogue, and in that catalogue we have printed descriptions of the shrubs, their habits, where to plant them and the proportions of their growth-I mean their height and breadth, the nature of their foliage, so that buyers will know where to plant, when to plant, and what to expect of what they plant.

I said that we lay the garden out then and there when we are requested or see the necessity. In all such cases we indicate what lines should be, or show the absurdity and monstrosity 
of lines that hit one another like bulls coming together head on; and the bad taste of hard angles and of lines or paths that get nowhere, but compel you to turn back on your tracks. In other words we show all the amenities of gardening; and then if we find the person still interested we say, "Take a hatchet and go down in the cellar, after I am gone, and split about three times as many little woden pins as you think I can possibly use, and have them on hand, and I will lay out the garden for you when I come back." So we do and the results have been very fine.

I want to go on, before I am asked any further question, to say that another aspect of our work, which came to us as a late afterthought-after, may be, five years of the movement had passed-was the neighborhood garden club. It seemed to us a great pity that we should have a garden here in a street, then two or three gardens neglected, and then no garden, and so on, and the moment we said, "Neighborhood Garden Clubs," they said "Everybody needs that." The Woman's Council grasped the idea and at once they began to bind the competitors into clubs, the main condition of whose entrance into competition was that they should be not necessarily all on one street, but all in one mass, of contiguous, absolutely contiguous gardens. To stop off that queer sort of human creature that lives everywhere, who cannot neglect his opportunity to hold up a movement, especially a neighborhood movement, we made the allowance that if anyone obstinately declines to stay out of the neighborhood club he can be gardened around; that the club can go that much farther and include another member, so that he is treated the same as if he were an empty lot or an untenanted house, that is, he counts for nothing; and when he counts for nothing he usually comes in. (Laughter.) It was an early thought on our part that this neighborhod garden competition-this neighborhood clubs competition might be a good thing, but we did not know. We puzzled for a long time to know how we should bestow prizes when the takers were numerous, until all at once it seemed to us that all we had to do was to bestow the prize and let them fight it out; and we found, to our great delight (in an experience which has up 
to this time had no exceptions after four years of the neighborhood garden clubs) that the winning club sends up its secretary to receive the award and takes it back to the clubs; and instead of distributing it pro rata throughout their numbers, they spend it all for shrubbery and put them back into the garden. So it pays in a double fashion. (Applause.) The prize is apportioned according to the number of gardens, so much for each garden in the club; so that if a neighborhood club consists of seven gardens-it cannot consist of lessit will take $\$ 7$ for the capital prize, or $\$ 3.50$ for the second prize, there being only two. If it has fifteen members it takes a capital prize of $\$ 15$ or $\$ 7.50$ if it has won the second prize. It takes this prize of $\$ 15$ because it has fifteen gardens in it. But that is not the only advantage it secures. Other things being equal, if the average rating of the fifteen gardens is as high as the average rating of the seven gardens and no higher, then the fifteen gardens take the prize, of course, since it is a greater achievement to maintain that standard throughout its larger number of gardens. This has worked charmingly, and the number of gardens has increased so in the neighborhoodgarden clubs that it is a serious question what we shall do about providing prizes. Our prizes began with $\$ 66$. At the last award of prizes, October, 1908, the prizes amounted to $\$ 175$.

Now, if you are going to have such a thing successfully carried on, and have no such institution as would take the place of the Home-Culture Clubs and furnish such untiring workers as the two secretaries we have, why, still you may have a flower-garden competition, but I fear you will have to make it much more expensive.

Ladies and gentlemen, I am very grateful to you for your kind attention. (Applause.)

The Chairman. We all thank Mr. Cable very much for his very interesting address, and are sorry he is obliged to go away, because he has to take the 4 o'clock train I understand, and his interest is so great I am afraid unless $I$ had hinted to him, he would have continued on, much to our satisfaction, and missed his train. 
Observing that Mr. Wm. M. R. French, Director of the Art Institute of Chicago, had entered the room, the Chairman called upon him for some remarks. Mr. French kindly consented to read a short paper on "The Proportion, Expression and Decoration of Art Galleries," delivered, the preceding day, in Philadelphia before the Convention of the American Museum Association, in the proceedings of which it will be printed.

The Chairman. After Mr. French's most interesting paper, which deals with subjects in which we are all surely interested, I am going to call upon Mr. William E. Curtis, if he will kindly come upon the platform. (Applause.) He needs no introduction from me.

\section{ADDRESS OF}

Mr. William E. Curtis.

Ladies and Gentlemen: I have been asked to pronounce the valedictory upon this very successful convention. We feel that we have done a good thing in calling you together, and we feel that you have had a good experience in coming here, and I wish to thank you, in behalf of the Regents of the National Academy of Art and the Committee on Arrangements, the delegates who have come, and especially the ladies and gentlemen who have given us such admirable papers. I do not remember ever to have attended a convention, especially the first, in a movement like this, where there were such splendid papers as we have had here, and I am sure that you have already gathered not only knowledge but inspiration from them. You have got a good deal of value in the way of ideas and suggestions, for this is a federation of workers and not of talkers.

The organization is capable of unlimited usefulness, and we want to do the best we can. Every society and every club that is trying to make the world more beautiful is entitled to membership. No society is too insignificant, for sometimes the most insignificant are the most important. You have all heard that whoever makes "two blades of grass to grow where one blade was growing before, is a benefactor to his: 
race," and whoever tells a child the name of a flower is educating that child.

The Committee has found it difficult to get the names and addresses of as many organizations as they wanted. A great many worthy and useful organizations which were working on the lines we want to follow were not invited to this convention because we did not know of their existence, but I want to ask every delegate and every person who is here now to send to our Secretary the names of every society he or she can think of. Please do that early and do it often-every time you hear of a society that should belong to this Federation send the name to the Secretary.

Senator Root proclaimed our creed. Now, let us live up to it. The importance of keeping up the enthusiasm, the importance of extending and communicating the inspiration that you have received here cannot be overestimated. The delegates when they go home should stir up their friends and neighbors and organize local clubs and State Federations. Get together. "In union there is strength," you know. Use your influence to bring all sorts of associations into communication with us. Remember that this is not a federation of professionalists; it is a federation of laymen, a federation of workers, without regard to profession, and only with regard to the capacity of the society to assist in developing the public taste and promoting the love for the beautiful. Everything in the success of this movement depends upon the activity of the individual. We have got a splendid lot of officers, and we are going to make them work; but they cannot be solely responsible, and we must not depend upon them to make this movement a success. In an altruistic enterprise like this there must be no dead wood and no drones. Therefore, we hope that the delegates will keep, and the societies they represent will keep, in constant touch with the headquarters in Washington, and bombard the Secretary with questions and suggestions of all kinds.

Then, there is lots of work for you to do at home. I was very much struck by a speech made by Delegate Read of Denver, who told us about the difficulty of securing proper instruction in the arts and crafts in the public schools. School 
teachers are not infallible, of course. The only infallible people are newspaper men (Laughter), and when they make mistakes you will always find that they have an excellent excuse-it was due to some extenuating circumstance-they, perhaps, were not as familiar with the facts as they should have been, or perhaps they overlooked the facts, or some reason of that sort. But this is a good organization to teach how to teach-at least to get in motion and place pressure and influence upon Boards of Education, Superintendents of Educaticn, faculties of normal schools and other agencies which have that work in hand, to give the teachers of schools a better training. You begin that work at the bottom; you begin it in the school board of your villages, with the principal of your high school and the superintendent of your local schools; and if the societies which compose this Federation should do nothing else but improve the effectiveness and perfect the training of the teachers in the public schools, its mission will have been very important.

The headquarters of this Federation will be in Washington. Some of the officials will always be here and at the command of the constituent societies, and we hope that you will let us hear from you frequently; we hope that you will call upon us for assistance and for advice, and we hope, especially, that you will send us the names of other societies, that the Federation may be enlarged.

There are one or two other minor matters of business to be disposed of before we separate; but in the name of the $\mathrm{Re}$ gents of the National Academy of Art and the Committee on Arrangements, I want to thank you again and bid you goodbye. (Applause.)

The Chairman. As Mr. Curtis said in his very interesting remarks, there are a few little matters of business. I think perhaps it would be well for me to explain, so that everybody can understand, the relation of the American National Academy of Art with this Federation, as it now stands, provided this Federation continues. There can be no Federation, to begin with, unless there are constituent societies. The Federation has just been organized; it will now be necessary for the societies to join the Federation. The National Academy of Art, 
which is the parent of the Federation, will in the future stand in relation to the Federation as one of the constituent societies. It will have nothing to do with it, it can have nothing to do with it except in that relation. It was necessary for some organization to start this, and it was Mr. Root's idea that it should be started in this way, the desire being to federate the art societies and the societies of those interested in the development of public taste, by calling them together through the means of the Executive Committee of the National Academy of Art, which has a Federal charter, as you know. This has been done; the Constitution has been drawn up and adopted by the delegates.

Now it is necessary for the different societies, after having adopted the Constitution, to express their willingness to affiliate, if they desire to become a part of the Federation.

There is also the question of finance to be considered.

Mr. GLENn Brown. We received from twenty-five to thirty letters from societies who are not represented here, saying that they wished to join the Federation as soon as organized. I have the letters, and they highly commend what we are trying to do. We have represented here about eighty associations and about twenty-five of them have already signified their intention of joining. It looks as if we had a pretty good start.

The Chairman. That is a very gratifying report. I am of those who believe that there exists in the American citizen an inherent love of the beautiful; it may be dormant; it may be lying fallow, but if you could remember, as I do, the time when a municipal ordinance prohibited the exhibition of the Venus de Milo in a shop window, and when the only art instruction there was in Boston was a model who posed himself every Thursday night, and anybody so inclined could go and draw from him. That was the only instruction in Boston when I began. See the difference now. Of course things go on very fast in this country, and I believe this is one of the means that will make things go very fast in this direction. It all depends on us, as Mr. Curtis said. It all depends upon every member of the organization that starts a propaganda; not to stop because we have organized. We have only started; we have only made the machinery; we have got to keep the machinery going. 
There has been a Committee on Organization appointed, with full powers to appoint a Board of Directors, from whom are to be selected the Executive Committee.

Mr. E. E. Garnsey. It seems to me the important thing, having created an organization, having filled ourselves with enthusiasm and a great many very happy suggestions, is to spread this butter over as much bread as possible. The butter is printer's ink. In the first place, the Constitution must be printed and sent to the constituent societies for their ratification, in order that this organization here effected shall become a vital organization. There are possibly funds-I do not know where they come from-to do these things. If not, I think before this convention is adjourned something should be done toward providing funds for printing the constitution, paying the postage and all that sort of thing, in order that as soon as possible, before our enthusiasm cools, or before other things come up to interest us, that this Constitution and, if possible, above all things, the addresses which have been delivered before this convention, shall be put into the hands of the people whom we wish to interest, who need to be interested in this movement. I think this convention should know, sir, whether there are funds for this purpose or not, and whether there are hopes of getting them, and whether we cannot do something to get those funds, in order that this movement may be vitalized, beginning now. (Applause.)

The Chairman. I can partly answer that question. The Executive Committee of the National Academy of Art raised a certain amount of money to provide for the expenses of this organization-of this Federation-a certain number of contributions have been sent in by the societies and the Treasurer of the National Academy of Art is here present. Perhaps he would be willing to say a few words upon the financial prospect of this Federation.

Mr. A. J. PARsons. The present situation is that some of the Regents of the Academy of Art and some of the organizations have contributed enough to pay the expenses of this convention, and also probably for the publications.

Mr. GaRnSEY. I wish to thank the Treasurer for this information. That being the case, I think this convention would: 
be glad to express its appreciation of the public spirit of the Regents of the National Academy of Art in having taken that initiative, and having made these things possible; and I offer that as a resolution.

It was adopted.

The Chairman. I have here an invitation: "The delegates to this convention are most cordially invited to visit the McKinley Manual Training School for White Children, 7th and $\mathrm{R}$ Streets, and the Armstrong Manual Training School for Colored Children, P Street, between 1st and 2d Streets." This is very interesting to those who are going to stay a day or two in Washington or even this afternoon.

Mr. Read. (Of Denver.) Ladies and Gentlemen, Fellow Delegates: It may seem to you presumptuous in me, an entire stranger, to speak as a personal friend. But if you will permit me, upon the score of being a delegate that has perhaps traveled the farthest to this convention, I would like to make a personal appeal to every one of my friends and fellow delegates. Let me speak to you all directly. If you are as much interested about this matter as I am and feel as strongly convinced as $I$ do that this convention marks an epoch in the history of American art and public taste, let me urgently ask you every one to work as you never worked before-each of you to constitute yourself a committee of one to spread the principles and faith of this Federation among your fellow workers and in your own communities. Having made this appeal, I feel that I need add nothing more to these few words of supplication. (Applause.)

The Chairman. I am glad Mr. Read said what he did, because it voices, I know, the sentiment of the West. And I must add my appeal also to that of Mr. Read's, that we shall not for a moment forget the mission we are engaged on, which is an altruistic-purely altruistic mission, to help our fellow men.

Is there any other business? Then, if there is no other business, I shall declare the convention adjourned, to meet at the call of the Board of Directors.

The Convention was then adjourned sine die. 
ORGANIZATIONS AND DELEGATES PARTICIPATING IN THE CONVENTION.

American Civic Association, Harrisburg, Pa.

Mr. J. Horace McFarland, Delegate.

American Institute of Architects, Washington, D. C.

Mr. Glenn Brown, Secretary.

American Society of Miniature Painters, New York.

Mr. Wm. J. Baer, President and Delegate.

American Water Color Society, New York.

Mr. James Henry Moser, Delegate.

Architectural League of New York.

Mr. C. Grant La Farge, Delegate.

Mr. Daniel C. French, Delegate.

Mr. H. W. Corbett, Delegate.

Mr. Wm. Laurel Harris, Delegate.

Mr. Wm. A. Boring, Delegate.

Architectural League of America.

Mr. C. C. Zantzinger, Delegate.

Mr. Frank C. Baldwin, President.

Art Association of New Orleans.

Mr. William Woodward, Delegate.

Art Commission, City and County of Denver.

Mr. Henry Read, Delegate.

ART Club, Logansport, Indiana.

Mrs. Ruth A. Winters (unofficially).

Mr. J. B. Winters (unofficially).

Art Institute of Chicago.

Mr. A. E. Albright, Delegate.

Mr. Wm. M. R. French, Director.

Art League, Public Education Association, New York

City.

Miss Florence N. Levy, Delegate.

Artists' Club of Denver.

Mr. Henry Read, Delegate.

Art Society of Pittsburgh.

Mr. Isaac E. Hirsch, Delegate. 
Art in Trades Club, New York.

Mr. Wm. S. Coffin, Delegate.

Arts and Crafts School, George Washington University.

Mr. Harry S. Michie, Delegate.

Miss Frances L. Thomson, Delegate.

Arundell Club, Baltimore, Md.

Miss Christiana Bond, Delegate.

Carolina Art Association, Charleston, S. C.

Miss Azalea Howard Willis (unofficially).

Charcoal Club of Baltimore, Md.

Mr. Fred H. Gottlieb, Delegate.

Mr. Thos. C. Corner, Delegate.

Mr. W. R. C. Wood, Delegate.

Chicago Society of Artists.

Mr. A. E. Albright, Delegate.

College Women's Club, Washington, D. C.

Mrs. Justina R. Hill, Delegate.

Connecticut State Commission of Sculptors, Hartford, Conn.

Mr. Charles Nöel Flagg, Delegate.

Connecticut Valley Historical Society, Springfield, Mass.

Mr. Nehemiah Hawkins, Delegate.

Copley Society, Boston, Mass.

Mr. H. Winthrop Peirce, Delegate.

Corcoran Gallery of Art, Washington, D. C.

Mr. A. J. Parsons, Delegate.

Corcoran School of Art.

Mr. E. C. Messer, Director.

Fine Arts Society, Detroit, Mich.

Mr. Frank C. Baldwin, Delegate.

George Washington University.

Dr. Chas. W. Needham, President.

Hamilton, N. Y., Art Club.

Mrs. H. S. Lloyd, Delegate.

Home-Culture Clubs, Northampton, Mass.

George W. Cable, Delegate.

International Congress for Teaching Art.

Mr. James Frederick Hopkins, Delegate.

Kansas City Fine Arts Association, Kansas City, Mo.

Mrs. Wm. P. Borland, Delegate. 
Laurel Hill Association, Stockbridge, Mass.

Mrs. James Lowndes, Delegate.

League for the Decoration of Public Schools, Washington, D. C.

Miss Grace Lincoln Temple, Delegate.

Mrs. Justina R. Hill, Delegate.

Mrs. Charles W. Richardson, President.

Mrs. George F. Bowerman, Delegate.

Maryland Institute, Baltimore, Md.

Mr. James Frederick Hopkins, Delegate.

Massachusetts Civic League.

Mr. E. J. Hartman, Delegate.

Mechanics Institute, Rochester, N. Y.

Mr. Frank von der Laucken, Delegate.

Metropolitan Improvement League, Boston, Mass.

Mr. Sylvester Baxter, Delegate.

Municipal Art Society, Baltimore, Md.

Mr. Theodore Marburg, Delegate.

Mr. Miles White, Jr., Delegate.

Mr. Josias Pennington, Delegate.

Mr. Jos. Evans Sperry, Delegate.

Mr. Hans Schuler, Delegate.

Mr. Wm. M. Ellicott, Delegate.

Municipal Art League of Chicago.

Mr. Wm. M. R. French, Delegate.

Municipal Art Society of Hartford, Conn.

Mr. Charles Nöel Flagg, Delegate.

Municipal Art Society of New York.

Mr. C. Y. Turner, Delegate.

National Academy of Art, Washington, D. C.

Mr. Glenn Brown, Secretary.

Hon. Elihu Root, Regent.

Hon. Francis G. Newlands, Regent.

Mr. Chas. L. Hutchinson, Regent.

Mr. Francis Colton, Regent.

Mr. Herbert Adams.

Mr. F. D. Millet, Regent.

Mr. A. J. Parsons, Regent.

Mr. Walter Scott Perry, Regent. 
Hon. Henry Cabot Lodge, Regent.

Mr. Henry Read, Regent.

Mr. Theodore Marburg, Regent.

Mr. William E. Curtis, Regent.

National Academy of Design, New York.

Mr. Herbert Adams, Delegate.

Mr. F. D. Millet, Delegate.

National Arts Club, New York.

Mr. Charles R. Lamb, Delegate.

National Sculptor Society, New York.

Mr. Eli Harvey, Delegate.

Mr. Isidore Konti, Delegate.

Mr. Bela Pratt, Delegate.

Mr. Karl Bitter, Delegate.

National Society of the Fine Arts.

Mr. Hennen Jennings, Delegate.

Prof. Geo. L. Raymond, Delegate.

Mrs. A. C. Barney, Delegate.

Mr. Marvin F. Scaife, Delegate.

Mr. Chas. J. Bell, Delegate.

Miss Leila Mechlin, Delegate.

National Society of Mural Painters, New York.

Mr. Elmer E. Garnsey, Delegate.

Mr. C. Y. Turner, Delegate.

New York Chapter, A. I. A.

Mr. George B. Post, Delegate.

Mr. D. Everett Waid, Delegate.

Mr. Henry Bacon, Delegate.

Orio Club, Ardmore, Okla.

Mrs. Anna Guy Addington, Delegate.

Peking University, Department Chinese Art.

Mr. Isaac Taylor Headland (unofficially).

Philadelphia Chapter A. I. A.

Mr. D. Knickerbacker Boyd, Delegate.

Mr. Albert Kelsey, Delegate.

Pittsburgh Chapter A. I. A.

Mr. Joseph L. Neal, Delegate.

Pratt Institute, Brooklyn, N. Y.

Mr. Walter Scott Perry, Delegate. 
Public Education Association, Washington, D. C.

Mrs. Chas. C. Darwin, Delegate.

Mrs. John Milton Gitterman, Delegate.

Quincy, Ill., Boulevard and Park Association.

Mr. Edward J. Parker, Delegate.

Rhode Island Avenue Suburban Citizens Association,

Washington, D. C.

Mr. Bristow Adams, Delegate.

School of Architecture, George Washington University.

Prof. Percy Ash, Delegate.

Sequoyah Art Club, Oklahoma.

Mrs. Anna Guy Addington, Delegate.

Society of Arts and Crafts, Detroit, Mich.

Mr. Frank C. Baldwin, Delegate.

Society of Beaux Arts Architects, New York.

Mr. W. W. Bosworth, Delegate.

Mr. Evarts Tracy, Delegate.

Mr. H. W. Corbett, Delegate.

Society of Central New York Artists.

Mrs. H. S. Lloyd, Delegate.

Society of Columbia University Architects, New York

City.

Mr. George Oakley Totten, Jr., Delegate.

Société des Architects Diplomés, New York.

Mr. J. H. Freedlander, Delegate.

Mr. Donn Barber, Delegate.

Society of Washington Artists.

Mr. Richard N. Brooke, Delegate.

Mr. Max Weyl, Delegate.

Mr. Lucien Powell, Delegate.

Mr. Ruel Pardee Tolman, Delegate.

Mr. E. H. Miller, Delegate.

State Art Society, St. Paul, Minnesota.

Miss Mary M. Newport, Delegate.

Suffern ART Club, New York State.

Mr. Francis Wheaten, Delegate.

T Square Club of Philadelphia, Pa.

Mr. C. C. Zantzinger, Delegate. 
The Archaeological Institute of America.

Prof. Mitchell Carroll, Delegate.

Mr. Geo. Oakley Totten, Jr., Delegate.

Miss Mabel Boardman, Delegate.

Mrs. Charles D. Walcott, Delegate.

Tree Planting Society of New York.

Mr. Chas. R. Lamb, Delegate.

The Royal Society of British Painters, London.

Mr. Alfred East, President (unofficially).

Tulane University of Louisiana, New Orleans.

Mr. William Woodward, Delegate.

Twentieth Century Club.

Mrs. Whitman Cross, Delegate.

University of Pennsylvania, School of Architecture.

Prof. Warren P. Laird, Delegate.

Village Improvement Society, Bluemont, Va.

Mrs. Charles G. Smith, Delegate.

Village Improvement Society, Litchfield, Conn.

Mrs. S. A. Willis, Delegate.

Waco Art League, Waco, Texas.

Mrs. R. L. Henry, Delegate.

Washington Architectural Club, Washington, D. C.

Mr. Ward Brown, Delegate.

Mr. Waddy B. Wood, Delegate.

Washington Chapter A. I. A.

Mr. J. R. Marshall, Delegate.

Mr. J. G. Hill, Delegate.

Mr. Thomas J. D. Fuller, Alternate.

Mr. Nathan Wyeth, Alternate.

Washington Water Color Club.

Miss Bertha E. Perrie, Delegate.

Mrs. S. A. Kimberley, Delegate.

Miss Aline E. Solomons, Delegate.

Woman's Club of Sterling and Rock Falls, Ill.

Mrs. L. B. Powell, Delegate. 



\section{N D E X.}

Pages

Adams, Dr. John Quincy..................... 82-87

Albright, Mr. A. E.......................... 56,57

Art Education in the United States, Address of Mr. Walter Scott Perry............ 132-142

Art in the Public Schools,

Address of Hon. E. E. Brown............... $50-54$

Baldwin, Mr. Frank C........................ 10

Baxter, Mr. Sylvester........................... 68,69-78

Brown, Mr. Glenn......................... 78, 163

Brown, Miss Martha Brookes.................... 157

Bryce, Rt. Hon. James, Ambassador from Great Britain,

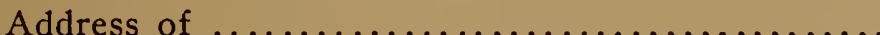

25-35

Cable, Mr. George W.......................... 144-159

Carroll, Prof. Mitchell........................ 100, 101, 102

Committee on Constitution and By-Laws............. 24

Report of $\ldots \ldots \ldots \ldots \ldots \ldots \ldots \ldots \ldots \ldots \ldots \ldots \ldots \ldots \ldots \ldots, 81,87$

Committee on Nominations........................ 24

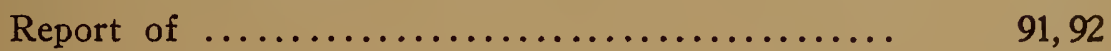

Committee on Programme........................ 35

Committee on Resolutions........................... 37

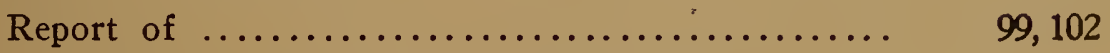

Common Sense in Decoration and Craftsmanship,

Address of Mr. Royal Cortissoz................ $\quad 60-64$

Constitution .................................. $\quad 88-91$

Cortissoz, Mr. Royal............................. 60-65

Cultivation of Taste, The,

Address of Miss Florence N. Levy............. $38-47$

Curtis, Mr. William E., Address of................ 160-162

Ellicott, Mr. Wm. M.............................. 35

French, Mr. Wm. M. R......................... 160

Garnsey, Mr. E. E............................ 164

Government Bureau of Fine Arts, A,

Address of Hon. Francis G. Newlands........... 11-15

Government and the Fine Arts, The,

Address of Miss Leila Mechlin................. 16-24

Hartman, Mr. Edward T......................... $110-117$

Harris, Mr. William Laurel................... 55, 65,66

Harvey, Mr. Eli.......................... 86, 156, 157

Hill, Mrs. Robert T......................... 55 
How the American Civic League Promotes Community Beauty,

Address of Mr. J. Horace McFarland............

Hutchinson, Mr. Charles L., Chairman................

$118-131$

3-82

International Congress of Architects,

Address of Mr. George Oakley Totten, Jr.........
Jennings, Mr. Hennen.........................

Pages

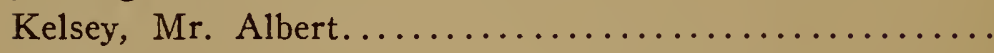

League for the Decoration of the Public Schools, Washington, D. C........................... 55

Levy, Miss Florence N......................

Marburg, Mr. Theodore....................... 36

McFarland, Mr. J. Horace....................... 117-131

Mechlin, Miss Leila........................... 16-24

Messer, Mr. Edmund C........................ 67

Metropolitan Improvement League of Boston,

Address of Mr. Sylvèster Baxter.............. $\quad 67-78$

Millet, Mr. Frank D., Chairman.................. 99-165

Needham, Dr. Charles W...................91, 92, 102, 103

Newlands, Hon. Francis G., Senator from Nevada....... 10-15

Northampton Prize Flower Garden Competition,

Address of Mr. George W. Cable............... 144-159

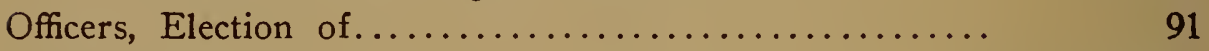

Parker, Mr. E. J.........................67, 102-110, 153

Parsons, Mr. A. J......................... 164

Peirce, Mr. H. Winthrop, Chairman............... $82-98$

Perry, Mr. Walter Scott...................... 131-140

Progress of Art in the Gulf States,

Address of Mr. William Woodward..............

Proportion, Expression and Decoration of Art Galleries,

The,

Address of Mr. Wm. M. R. French.............

Public School Art Society of Chicago..................

Purpose of the Convention,

Address of Hon. Elihu Root..................

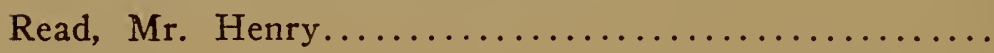

Resolutions :

Appreciation of President Taft's Support of Park

Commission Plan ......................

In Favor of Systematic Plan for Development of

Washington City .......................

In Favor of National Bureau of Fine Arts..........

In Favor of Washington Memorial Building.........

In Reference to Opening Vista to St. Peter's, Rome. .

93-98

160

54

6-9

58,165

Of Thanks for Hospitality.....................

78

99

100

100,101

102

102

Of Appreciation of the Life of Charles M. Ffoulke..

102 


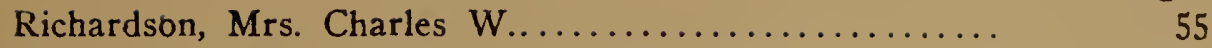

Root, Hon. Elihu, Senator from New York............ 6-9

Sessions:

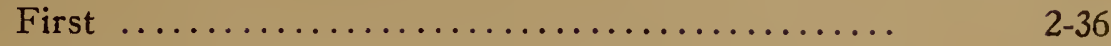

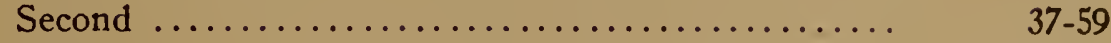

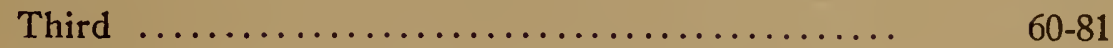

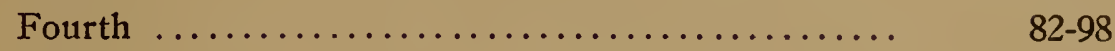

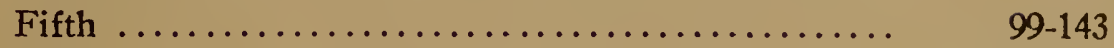

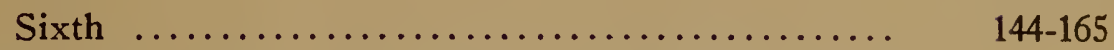

Sherman, Hon. James Schoolcraft, Vice-President of the United States,

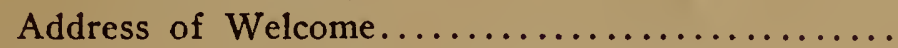

Some Aspects of Municipal Art Improvement,

Address of Mr. Edward T. Hartman........... 111-117

Temple, Miss Grace Lincoln................... 56, 57

Totten, Mr. George Oakley, Jr................. 87

Townsend, Mr. James B................................. 141

Traveling Exhibitions, Discussions of............. 141, 142

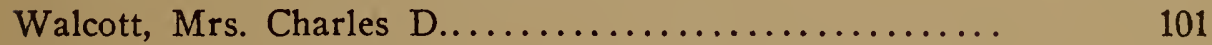

What Can Be Done by Co-operation for Outdoor Art,

Address of Mr. E. J. Parker................. 104-110

Woodward, Mr. William Woodward.............92-98, 142, 143

Work of the Art Commission of the City of New York,

Address of Dr. John Quincy Adams............ $82-86$ 

